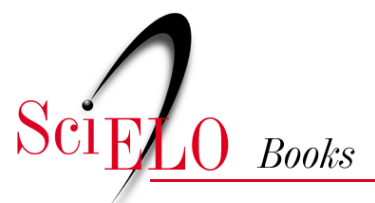

\title{
Três ensaios de bioética
}

\author{
Fermin Roland Schramm
}

SHRAMM, F. R. Três ensaios de bioética [online]. Rio de Janeiro: Editora FIOCRUZ, 2015, 177 p. ISBN: 978-85-7541-586-3. https://doi.org/10.7476/9788575415863.

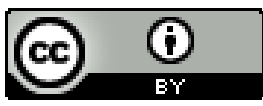

All the contents of this work, except where otherwise noted, is licensed under a Creative Commons Attribution 4.0 International license.

Todo o conteúdo deste trabalho, exceto quando houver ressalva, é publicado sob a licença Creative Commons Atribição $\underline{4.0}$. 


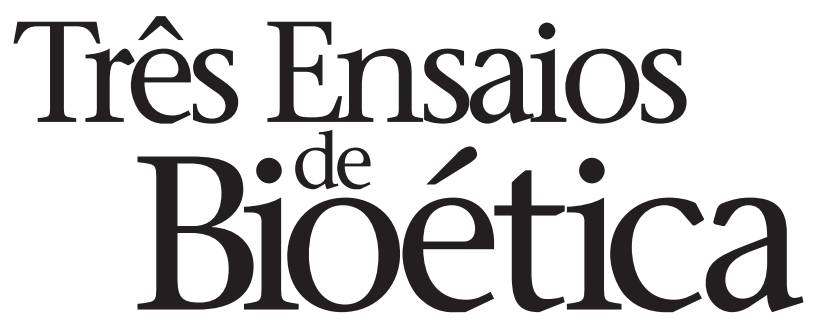




\section{FUNDAÇÃO OSWALDO CRUZ}

Presidente

Paulo Gadelha

Vice-Presidente de Ensino, Informação e Comunicação

Nísia Trindade Lima

\section{EDITORA FIOCRUZ}

\section{Diretora}

Nísia Trindade Lima

Editor Executivo

João Carlos Canossa Mendes

Editores Científicos

Carlos Machado de Freitas

Gilberto Hochman

Conselho Editorial

Claudia Nunes Duarte dos Santos

Jane Russo

Ligia Maria Vieira da Silva

Maria Cecília de Souza Minayo

Marilia Santini de Oliveira

Moisés Goldbaum

Pedro Paulo Chieffi

Ricardo Lourenço de Oliveira

Ricardo Ventura Santos

Soraya Vargas Côrtes 


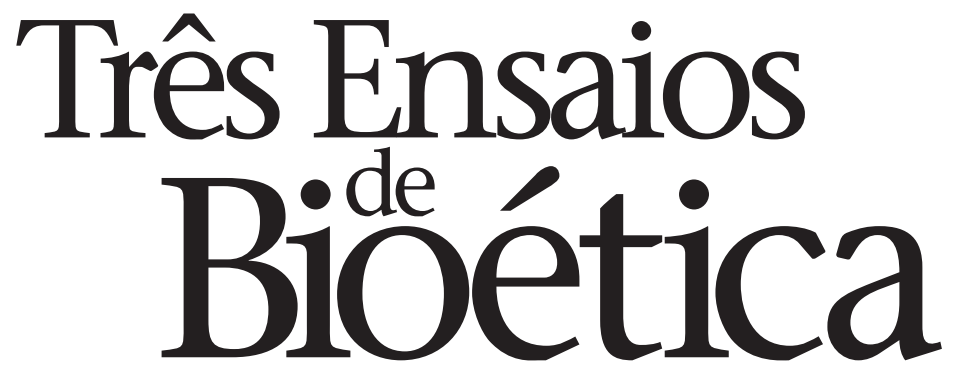

Fermin Roland Schramm 
Copyright (C) 2015 do autor

Todos os direitos desta edição reservados à

Fundação Oswaldo Cruz / Editora

Revisão

Jorge Moutinho

Irene Ernest Dias

Normalização de bibliografia

Clarissa Bravo

Capa, projeto gráfico e editoração eletrônica

Fernando Vasconcelos

Catalogação na fonte

Instituto de Comunicação e Informação Científica e Tecnológica

Biblioteca de Saúde Pública

S377t Schramm, Fermin Roland

Três ensaios de bioética. / Fermin Roland Schramm Rio de Janeiro : Editora FIOCRUZ, 2015.

$177 \mathrm{p}$.

ISBN: 978-85-7541-455-2

1. Bioética. 2. Biotecnologia. 3. Tomada de Decisões.

4. Moral. 5. Qualidade de Vida. 6. Risco. I. Título.

CDD - 22.ed. - 174.957

2015

EDITORA FIOCRUZ

Av. Brasil, 4.036 - Térreo - sala 112 - Manguinhos

Editora filiada

21040-361 - Rio de Janeiro, RJ

Tels.: (21) 3882-9039/3882-9041

Fax: (21) 3882-9006

editora@fiocruz.br

Associação Brasileira

www.fiocruz.br/editora 


\section{Sumário}

$\begin{array}{ll}\text { Prefácio } & 7\end{array}$

$\begin{array}{ll}\text { Apresentação } & 11\end{array}$

1. Questões Conceituais da Bioética Clínica: é possível uma metabioética realista?

2. A Bioética e a Moralidade da Genômica 67

3. Bioética 'e/ou' Biossegurança: uma possível interface na avaliação e gestão da prática da biotecnociência?

$\begin{array}{ll}\text { Referências } & 167\end{array}$ 


\section{Prefácio}

A história da bioética no Brasil está indelevelmente escrita com o nome de alguns ilustres precursores, e Fermin Roland Schramm tem o seu registrado em qualquer versão que se escreva. Formado em linguística pela Universidade de Genebra, na Suíça, completou seu mestrado em semiótica na École des Hautes Études en Sciences Sociales em 1978 na França e doutorou-se em saúde pública na Escola Nacional de Saúde Pública da Fiocruz em 1993. Realizou seu pós-doutorado em bioética na Universidade do Chile. Pensador original, rigoroso no método e nos conceitos, Schramm tem sua trajetória acadêmica marcada em sua produção científica, bem como a sua compreensão da vida social e política de nossos tempos. Tendo o olhar sanitarista e a busca pela justiça como compromisso político e social, propôs a incorporação da proteção de indivíduos e populações vulneradas como uma das tarefas da bioética e em seu fundamento.

Mais do que um pensador que contribui para o desenvolvimento da bioética no Brasil, Roland é uma das lideranças acadêmicas que procuram fomentar uma reflexão em bioética original no âmbito da América Latina. Entendendo, como não podia deixar de ser, que as contribuições originárias de pensadores de alhures não devem ser desconsideradas, Roland se insere no debate filosófico sobre os fundamentos e a aplicação das teorias no contexto latinoamericano. Sua formação e sua prática enfatizam o debate no campo teórico e não no meramente ideológico, o que não afasta a ação política, mas a qualifica. O presente livro, Três Ensaios de Bioética, insere-se nesse contexto, e é uma contribuição significativa para todos que estejam comprometidos com o desenvolvimento teórico da bioética e, como não poderia deixar de ser, em sua aplicação na solução dos conflitos morais.

O professor Schramm foi, de 1997 até 2014, consultor em bioética do Instituto Nacional do Câncer no Rio de Janeiro, onde criou e coordenou o Conselho de Bioética. Nesse período teve a oportunidade de se aproximar do processo clínico, o que o levou a uma experiência concreta de debate com os 
profissionais da saúde envolvidos no cuidado em um hospital especializado. Para além da discussão geral da formulação política e das decisões mais próximas do campo da saúde pública, incorporou a experiência de conduzir seminários sobre oncologia pediátrica e cuidados paliativos.

Vejo o primeiro ensaio deste livro como um reflexo dessa experiência: como avaliar as situações relacionadas com a chamada bioética clínica, ou seja, com o cuidado individualizado de pacientes? Trata-se, aqui, de discutir não um método para a solução dos problemas morais, mas a possibilidade, e sua eventual importância, da análise criteriosa de conceitos. Schramm absorve a tarefa da filosofia analítica sem deixar dúvidas de que vê na bioética "a superação da tradicional oposição entre as vertentes analítica e continental em filosofia". Àqueles familiarizados com a contribuição teórica de Schramm, esse ensaio fundamenta teoricamente o que é tão característico em sua produção acadêmica: o cuidado com a precisão dos conceitos e com a análise estrita dos fatos e argumentos relacionados, aqui aplicados à reflexão sobre a pertinência de se pensar em uma metabioética clínica realista.

Os dois ensaios que completam a obra se caracterizam pelo mesmo cuidado analítico e com a precisão conceitual e metodológica. Um deles, o segundo, aborda a moralidade da genômica. Tema atual e dos mais relevantes para a análise bioética, é discutido por Schramm com uma abordagem que contempla a identificação dos argumentos favoráveis e contrários à engenharia genética. Entendo que embora sejamos contemporâneos de um grande avanço no conhecimento genético e em sua aplicação para pesquisas e na clínica, esse conhecimento ainda parece aterrorizar segmentos significativos de nossa sociedade, que ainda se preocupam com a possibilidade de que certas práticas, aceitas para animais não humanos e vegetais, sejam aplicadas a seres humanos. Esse temor é, de fato, inibidor do debate, mas não do desenvolvimento técnico e tecnológico. Nesse ensaio, Schramm traz fatos e argumentos para o foco da atenção dos leitores, contribuindo para o desenvolvimento do raciocínio crítico e sem preconceitos sobre o tema.

Trabalho semelhante é feito no terceiro ensaio, intitulado "Bioética 'e/ ou' biossegurança: uma possível interface na avaliação e gestão da prática da biotecnociência?", em que Schramm discute a interface entre bioética e 
biossegurança em um contexto social em que o risco produzido é inerente ao desenvolvimento da sociedade moderna. Mais uma vez o autor se utilizará da etapa de elucidação conceitual como condição indispensável para que a análise crítica seja feita de forma imparcial, distinguindo os conceitos de risco, perigo e dano, para então apresentar e discutir as possibilidades teóricas de enfrentamento dos problemas morais relacionados.

O privilégio de escrever este prefácio e oferecer ao leitor alguns elementos adicionais para a compreensão destes ensaios é ainda mais especial para mim, que tive também o privilégio de ter o professor Roland como orientador no meu processo de doutoramento e com ele conviver no Programa de Pós-Graduação em Bioética, Ética Aplicada e Saúde Coletiva, programa que, de forma inédita e inovadora no campo da bioética, associou as principais instituições de ensino superior do estado do Rio de Janeiro: Universidade Federal do Rio de Janeiro, Universidade Federal Fluminense, Universidade do Estado do Rio de Janeiro e Escola Nacional de Saúde Pública da Fiocruz.

Com muita frequência as pessoas que cumprem o papel de prefaciar um livro falam de quão indispensável o livro em questão é, para tal ou qual população. Sem querer cair no lugar-comum, gostaria de salientar que este segundo livro autoral de Fermin Roland Schramm, pesquisador com quase duzentos trabalhos publicados, preferencialmente em periódicos científicos, representa o início do pagamento de uma dívida para com a comunidade acadêmica dedicada ao estudo da bioética, pois em um livro o autor se vê liberto das limitações impostas pelos periódicos em relação ao número de páginas e mesmo de referências. Temos neste livro, ainda que organizado como a reunião de três ensaios, acesso aos fundamentos teóricos com os quais o autor debate para construir suas formulações. Que este seja o primeiro de uma série de textos em que Schramm possa dialogar mais amplamente com os autores referenciados, propiciando a mais ampla compreensão de sua trajetória analítica aos seus leitores.

Sergio Rego

Pesquisador titular da Escola Nacional de Saúde Pública Sergio Arouca/Fundação Oswaldo Cruz 


\section{Apresentação}

Cada um dos três ensaios aqui reunidos - "Questões conceituais da bioética clínica: é possível uma metabioética realista?", "A bioética e a moralidade da genômica" e "Bioética 'e/ou' biossegurança: uma possível interface na avaliação e gestão da prática da biotecnociência?" - tem sua relativa autonomia, mas trata também de temas mais gerais que atravessam todos eles. Pode-se, portanto, dizer que tais temas são transversais, o que implica uma indisciplina resultante de um cruzamento livre entre os saberes envolvidos.

O primeiro tema é de ordem epistemológica e diz respeito à pertinência e legitimidade do uso da "caixa de ferramentas" chamada bioética para analisar, descrever, compreender e tentar resolver os conflitos de interesses e de valores que podem surgir na relação que se estabelece entre um profissional da saúde e os usuários dos serviços pelos quais este é responsável. Em particular, a conflituosidade pode se manifestar entre médico e paciente durante o set clínico, prevalentemente orientado pelo objetivo da cura, mas podendo ser norteado, em determinados casos em que a cura seja vista como impossível (ou improvável), pelos simples cuidados (que podem ser paliativos) oferecidos ao paciente.

Esse tipo de análise crítica dos conceitos e argumentos utilizados na avaliação e normatização da práxis no campo das ciências da vida e da saúde é feito, tradicionalmente, pela metaética e, no caso específico analisado no primeiro ensaio, pela metabioética - de acordo com a denominação aqui proposta para indicar o tipo de metaética utilizado pela bioética clínica e que denominamos metabioética clínica. Ou seja, nos três ensaios, tal estatuto é olhado no âmbito consagrado de sua aplicação - a prática clínica no primeiro ensaio, a terapia genética no segundo e a ponderação entre riscos e benefícios no terceiro -, mas é também considerado independentemente de tais âmbitos específicos - constituídos respectivamente pela clínica médica, pela genética e pela biossegurança - ou de novos campos interdisciplinares e transdisciplinares em gestação - como aquele da inter-relação entre bioética e biossegurança. 
Esse tema é abordado no primeiro ensaio, no qual nos perguntamos se o tipo de análise de segunda ordem, constituído pela metabioética, pode ter efeitos práticos significativos, tornando-se autênticos fatos, como proposto pelo pragmatismo e pela teoria dos atos de fala.

O segundo tema diz respeito à conflituosidade, considerada intrínseca ao ethos, que pode ser visto como o lugar onde se elaboram e se dão as práticas humanas, criadoras de conflitos, mas também as tentativas de resolvê-los graças à construção de possíveis mediações (ou convergências). E o terceiro tema está vinculado à questão metodológica da interdisciplinaridade, ilustrada em uma possível interface estabelecida entre bioética e biossegurança na avaliação da problemática dos riscos, implicada pela vigência do paradigma biotecnocientífico.

Em particular, no campo teórico aqui defenderemos a pertinência e a legitimidade de uma possível metabioética realista, considerada como uma das ferramentas analíticas da forma de ética aplicada conhecida como bioética, e que pode ser vista como uma discussão pertinente e legítima se considerarmos que essa separação entre primeira ordem e segunda ordem "tende a se desvanecer porque as diferenças nas concepções sobre a estrutura [da bioética] têm implicações para os problemas de primeira ordem, relativos à tomada de decisão" (Blackburn, 1997a: 246). O que não implica que devamos renunciar também a distingui-las, como tentaremos mostrar apresentando o debate entre realismo e idealismo desenvolvido, em particular, pela assim chamada Italian theory. Em seguida, abordaremos o tema da moralidade da prática humana no campo da genômica, considerando esta disciplina como um dos principais âmbitos das atividades da biotecnociência, abordadas pela bioética.

Aqui, no entanto, devemos explicitar o que entendemos por moralidade, pois o termo indica - de acordo com uma definição de dicionário - a qualidade ou característica do que é moral, ou - dito de maneira menos genérica - a qualidade da ação humana, avaliada de acordo com um juízo de valor que, em princípio, permite dizer se tal ação está ou não correta em determinada situação conflituosa. Assim, o estudo da moralidade deverá ter em devida conta tanto as indicações da deontologia como a kantiana - baseada na boa vontade diante dos deveres que devem ser respeitados independentemente de 
suas consequências em termos de bem-estar e qualidade de vida do agente moral - como aquelas da teleologia utilizadas pelo consequencialismo e o utilitarismo, que - como os termos indicam - avaliam as consequências e a utilidade, tanto para os indivíduos como para a sociedade, de determinados comportamentos humanos, independentemente dos deveres norteadores que possam estar envolvidos. Aqui entenderemos o termo moralidade no sentido técnico de característica do ato humano, analisada e julgada de acordo com parâmetros valorativos que permitam dizer se este é correto ou incorreto, justo ou injusto, em determinada situação, e tendo em conta não somente as boas intenções (exigidas pela deontologia), mas também suas boas ou más consequências (exigidas em particular pelo utilitarismo).

Como já lembramos, tais temas perpassam os três ensaios, que podem, portanto, ser vistos como partes de um conjunto único atinente ao complexo campo da bioética-constituído nas tentativas de comunicação (ou de negociação) para resolver situações conflituosas -, com metodologia que pode ser vista como ao mesmo tempo multidisciplinar, interdisciplinar e transdisciplinar, e inscrita no contexto social das sociedades democráticas e pluralistas atuais. De fato, segundo Gilbert Hottois (2003a: 480), as sociedades contemporâneas podem ser "caracterizadas pela diversidade cultural, tradicional, religiosa, comunitária, filosófica, moral, etc.", a qual "atinge a própria percepção dos factos e das questões, [e] a fortiori das respostas e soluções apresentadas", e "[tendo] em consideração essa diversidade [que] constitui um imperativo metodológico capital". Entretanto, cada ensaio tem também sua identidade própria, embora contemple, de forma transversal, conteúdos também presentes nos outros dois.

O primeiro ensaio é a reelaboração de um artigo publicado em 2012 em que nos ocupamos da análise conceitual referente às ferramentas da bioética clínica a partir da pergunta - aparentemente contraintuitiva - quanto a ser possível uma metabioética realista, e respondendo de maneira afirmativa. Nele procuramos mostrar que não existe uma diferença significativa quando as ferramentas da metatética são aplicadas à ética ou à bioética, podendo-se, portanto, utilizar pertinentemente o neologismo metabioética, entendido como uma especificação da metaética quando suas ferramentas são aplicadas para 
avaliar a cogência e consistência dos argumentos morais utilizados nos conflitos bioéticos.

No segundo ensaio, inédito, aplicamos as ferramentas da bioética ao caso dos conflitos morais envolvidos pelas práticas no campo da engenharia genética baseada no saber-fazer da genômica, e tentando mostrar que conflitos podem ser esses e como as ferramentas da ética aplicada chamada bioética permitem abordá-los.

O terceiro ensaio é uma revisão e o aprofundamento de um capítulo de livro bastante antigo, em que, pela primeira vez, discutimos as possibilidades de que dois tipos de saber distintos - a bioética e a biossegurança - estabeleçam entre si uma interface pertinente e justificada na avaliação e gestão da prática biotecnocientífica, tendo em vista a solução de seus conflitos e a possível complementaridade das duas caixas de ferramentas.

Mais especificamente, a temática do primeiro ensaio é, sobretudo, de tipo conceitual e metodológico, pois nele analisamos a possibilidade de associar dois âmbitos considerados inconciliáveis: aquele do real em que se dão as práticas dos profissionais clínicos (principalmente médicos) e aquele dos problemas conceituais e metodológicos envolvidos e analisados pela metabioética. De fato, o que faz que os dois âmbitos sejam aparentemente separados é a distinção consagrada entre atividade de primeira ordem, referente ao que se deve fazer e a como se comportar em determinadas condições - os fatos morais a serem analisados pela bioética -, e atividade de segunda ordem, a qual investiga os conceitos e os métodos utilizados no estudo dos referidos fatos morais avaliando a cogência dos argumentos em pauta que servem para justificar as práticas na clínica.

Entretanto, a pergunta se é possível uma metabioética realista deverá enfrentar a possível objeção segundo a qual tal possibilidade não existe conceitualmente, por ser a consequência de uma falácia de raciocínio, pelo menos se considerarmos que o adjetivo realista se aplica normalmente a um estado de coisas em princípio independente do conhecimento (ou das ideias) que elaboramos sobre ele e que deveria, portanto, ser separado do real enquanto tal. O neologismo metabioética, por sua vez, deverá se referir a uma atividade dita de segunda ordem, constituída pela análise racional e imparcial dos conceitos, 
juízos e argumentos morais, assim como dos métodos utilizados no processo de análise. Em suma, devido a essa distinção entre atividades de primeira e de segunda ordem, a metabioética não poderia se ocupar propriamente de problemas práticos, vivenciados no real, reservando suas ferramentas analíticas para os problemas teóricos, ou seja: lógicos, semânticos e epistemológicos, em princípio independentes dos problemas normativos, inclusive de acordo com a distinção, feita pelos linguistas, entre linguagem e metalinguagem. Entretanto, os problemas abordados pela bioética têm, além de uma dimensão teórica, uma dimensão necessariamente prática, visto que se referem, em última instância, àquilo que deveríamos fazer e a como deveríamos nos comportar em uma situação conflituosa que envolve seres vivos.

Aqui, sustentaremos a tese de que é possível pensar uma metabioética realista, e defendê-la, partindo do pressuposto de que a distinção lógica entre problemas de primeira ordem e problemas de segunda ordem não implica a sua separação, uma vez que a maneira como a bioética aborda a conflituosidade vigente no set clínico pode ser vista como inseparável de uma análise dos conceitos e métodos envolvidos na argumentação, como nos ensina o método da complexidade - pois as diferenças nas concepções éticas podem ter implicações sobre as próprias tomadas de decisão. É o caso, por exemplo, dos embates, ainda atuais, sobre sacralidade e qualidade de vida e, consequentemente, sobre bioética laica e bioética religiosa, isto é, entre aqueles que remetem, em suas avaliações da moralidade da práxis humana, à sacralidade da vida ou, ao contrário, à qualidade de vida. Ou seja, de acordo com o bioeticista Maurizio Mori, entre uma concepção que "indica a inviolabilidade ou intangibilidade da vida humana" e outra que "afirma como valor fundamental a qualidade da vida humana entendida como bem-estar e/ou como respeito à autonomia das pessoas" (2002: 17). Em suma, propor uma metabioética realista implica salientar o fato de que uma análise pode ter efeitos práticos, como indica a expressão atos de fala, da linguística pragmática, nos quais dizer e fazer são inseparáveis, pois, em determinadas situações, ao dizer algo realizamos um ato locutório que tem seus efeitos práticos sobre os envolvidos, e que a bioética se propõe a abordar.

A segunda temática é mais especificamente prática, embora não separada dos problemas teóricos da primeira, pois aborda a moralidade das práticas da 
genômica - ou seja, a qualidade dos atos humanos analisados e julgados de acordo com valores morais que permitam dizer se estão corretos ou não -, considerando a genômica como um dos principais âmbitos da biotecnociência. Esta entendida como o conjunto de ferramentas tanto teóricas (por ser uma ciência) como técnicas (por ser uma tecnociência) e práticas (por envolver vários tipos de atores), que buscam, conjuntamente, conhecer e transformar seres e processos vivos tendo em vista o bem-estar de indivíduos e populações. $\mathrm{Ou}$, mais simplesmente, para evitar danos ou controlar riscos considerados desnecessários e, portanto, em princípio evitáveis.

Aqui a pergunta norteadora dessa temática será se o trabalho dos profissionais da genômica é moralmente justificável ou questionável, tendo em conta não somente a produção logoteórica de conhecimentos e a capacidade técnica de transformar os seres vivos, mas também (ou sobretudo) os possíveis efeitos positivos ou negativos sobre a qualidade de vida dos seres humanos envolvidos, dos animais e dos sistemas vivos em geral (como os ecossistemas). Entretanto, tal pergunta parece ser contraintuitiva, por aparentemente questionar a liberdade humana de conhecer e pesquisar, o que seria contrário à própria história da cultura científica e à melhoria da condição humana graças à produção do saber. Mas, de fato, a pergunta se mostra pertinente quando se levam em conta os dispositivos de poder e de biopoder envolvidos nessa produção, que implicam relações de poder entre pesquisadores, sujeitos e populações investigados, a indústria e o mercado, sendo que tais relações de poder (e biopoder) resultam em conflitos de vários tipos, a começar pelos conflitos de interesses entre atores envolvidos, um dos problemas mais discutidos pela bioética nas últimas décadas, mas também conflitos entre visões de mundo aparentemente inconciliáveis, baseados, entre outros, em preconceitos não justificados.

Assim, pode-se falar pertinentemente em moralidade da genômica, entendendo com esta expressão uma dimensão que pode ser objeto de estudo da bioética, uma vez que a genômica, entendida como âmbito do saber-fazer biotecnocientífico, envolve tanto conhecimentos teóricos como práticas e técnicas, constitutivas dos dispositivos, entendidos - de acordo com Foucault como redes de relações "que podem ser estabelecidas entre elementos heterogêneos: discursos, instituições, (...) regramentos, leis, medidas administrativas, 
enunciados científicos [e que estabelecem] a natureza do nexo que pode existir entre esses elementos" (Castro, 2009: 124); ou - segundo a reinterpretação de Agamben - como "a capacidade de capturar, orientar, determinar, interceptar, modelar, controlar e assegurar os gestos, as condutas, as opiniões e os discursos dos seres vivos" (2006: 22).

A terceira temática é, em parte, um desdobramento da segunda, mas está também relacionada com a primeira, pois parte da pergunta se as duas caixas de ferramentas, representadas pela bioética e pela biossegurança, são não somente distintas, mas também separadas, ou, então, se são indissociáveis, pois apesar de atuarem em âmbitos específicos, teriam alguma relação entre si, o que indicamos pelo termo técnico interface. Em realidade, existe uma espécie de "ar de família" entre as duas caixas de ferramentas, pois ambas são consideradas pertinentes para estudar e avaliar as práticas, seus produtos e dispositivos resultantes da vigência do paradigma biotecnocientífico - "o conjunto de ferramentas teóricas, técnicas, industriais e institucionais que visam entender e transformar seres e processos vivos, de acordo com necessidades/desejos de saúde [e] visando [ao] bem-estar de indivíduos e populações humanas" (Schramm, 2005: 21) - no campo das ciências da vida, devido, sobretudo, à sua periculosidade (real ou potencial) que pode afetar a qualidade de vida de indivíduos e populações humanas, e de animais não humanos, assim como a qualidade dos ambientes naturais, tanto no presente como no futuro.

Nesse sentido, as duas caixas de ferramentas podem servir para abordar, em particular, a questão dos riscos implicados pelo saber-fazer biotecnocientífico na idade da sociedade global de riscos, na qual qualquer atividade humana que envolva seres e sistemas vivos parece ter se tornado uma fonte de ameaças não mais elimináveis, visto que o risco se tornou uma característica da condição humana (Beck, 2007). Parece, portanto, legítimo falar em interface desses dois tipos de saber (a bioética e a biossegurança), pois, no contexto da sociedade do risco estrutural e global, eles parecem compartilhar uma preocupação normativa comum e se ocupar dos mesmos tipos de problema, tais como a avaliação do uso das biotecnologias e, em particular, a ponderação entre riscos e benefícios sociais envolvidos pelo saber biotecnocientífico. $\mathrm{E}$ isso mesmo que cada saber os aborde de maneira específica, ou seja, apesar de tais problemas não serem abordados da mesma maneira, visto que bioética e biossegurança são 
também saberes distintos que não podem ser confundidos. Afinal, a primeira é um novo âmbito específico da ética, que se ocupa inter alia dos riscos do ponto de vista dos valores morais vigentes em uma sociedade complexa, e a biossegurança pode ser vista como um novo âmbito de estudo que se ocupa dos riscos biológicos (chamados biorriscos) lançando mão de medidas técnicas, administrativas e também legais (como mostram as várias leis de biossegurança, inclusive no Brasil). Assim, parece que bioética e biossegurança compartilham problemas comuns, como aquele dos riscos, embora não sejam abordados da mesma maneira e com o mesmo tipo de olhar.

Mas falando em interface, queremos destacar, sobretudo, que é possível um diálogo entre campos problemáticos distintos que não são separados, razão pela qual a relação entre eles deve ser vista como uma relação complexa, se é verdade que a complexidade implica saber distinguir sem separar e juntar sem confundir (Schramm, 2010a) problemas e soluções. Em particular, o termo interface se mostra adequado se pensarmos que a biossegurança pode precisar da legitimação valorativa da bioética para justificar moralmente seus procedimentos de controle aplicados à sociedade de riscos, e porque a bioética pode encontrar na biossegurança uma aliada para estabelecer um terreno comum no qual se possa estabelecer um diálogo normativo profícuo entre legitimidade e legalidade, diante dos graves problemas representados pelos riscos globais.

A tradução dos trechos citados ao longo dos três ensaios é de nossa inteira responsabilidade. 


\section{Questões Conceituais da Bioética Clínica: é possível uma metabioética realista?*}

A pergunta se é possível uma metabioética realista pode parecer descabida, por supostamente remeter a uma contradictio in terminis, em consequência de um raciocínio errado e, portanto, não pertinente nem justificada. O argumento que se pode aduzir é que o neologismo metabioética (aqui proposto) só poderia ser usado com pertinência se - de acordo com a distinção entre ética e metaética - entendêssemos metabioética como atividade ou ferramenta que só se ocuparia dos conceitos e métodos utilizados pela bioética, constituindo, portanto, um discurso de segunda ordem. Este teria por objeto de análise o(s) discurso(s) de primeira ordem, representado(s) pelas reflexões e julgamentos morais referidos a questões empíricas (como o modo correto, ou não, de se comportar em determinada situação conflituosa). Ademais, o adjetivo realista só se aplicaria à representação de objetos concretos; ou seja, pertenceria a uma concepção que considera o real como independente e preexistente às ideias que podemos ter (e construir) sobre ele - e que deve, por isso, ser em princípio distinto, embora não necessariamente separado (pelo menos se adotarmos uma postura construtivista), dos conceitos (ou ideias) que lhe aplicamos (ou construímos sobre ele).

\footnotetext{
* Reelaboração e ampliação do artigo "Questões conceituais e metaéticas da bioética clínica: uma introdução”, publicado na revista Bioethikos, 6(2): 125-132, 2012.
} 
Dito de maneira um pouco mais precisa, a metabioética se referiria, por definição, a uma atividade de segunda ordem que consiste em uma análise crítica dos conceitos, juízos e argumentos morais utilizados em uma disputa, assim como dos métodos utilizados pela bioética. Preocupa-se, portanto, tanto com problemas semânticos (como o significado dos termos morais utilizados, que pode não ser o mesmo entre os atores envolvidos) e problemas lógicos (como a cogência - ou validade - dos argumentos morais em campo) quanto com problemas ontológicos (como a existência e a identidade dos fatos morais analisados) e problemas epistemológicos (que dizem respeito à natureza de tais fatos morais e à pertinência do conhecimento moral), e que devem ser distintos dos problemas normativos (referentes àquilo que deve ser feito) (Mautner, 2010a).

Em outros termos, a metabioética (entendida como campo de objetos de segunda ordem) não deveria se preocupar diretamente com os problemas práticos (ou normativos) de primeira ordem, que se referem ao comportamento concreto resultante dos deveres e regras morais que deveriam orientá-lo. A metabioética teria, portanto, como objeto de estudo não tanto o comportamento e os atos humanos pertinentes para a bioética, mas as maneiras como os seres humanos representam, analisam, valorizam e justificam tais atos, realizando sua vida moral de maneira consciente, crítica e responsável, no contexto amplo do mundo vital (ou Lebenswelt), cada vez mais formado e modificado pelas competências humanas específicas de transformação de sua infraestrutura pela economia e pela biotecnociência. Assim sendo, se aceitarmos a distinção lógica entre problemas de primeira ordem e de segunda ordem, não poderemos, a rigor, falar em metabioética realista, pois o termo poderia ser considerado como resultado de uma confusão entre a ordem referida àquilo que é e a ordem daquilo que simbolizamos a partir daquilo que é.

Entretanto, aqui defenderemos a tese de que é possível uma metabioética realista, considerada uma das ferramentas analíticas da forma de ética aplicada conhecida como bioética, e que pode ser vista como pertinente e legítima se considerarmos que a separação entre primeira e segunda ordem "tende a se desvanecer porque as diferenças nas concepções sobre a estrutura [da bioética] têm implicações para os problemas de primeira ordem, relativos à tomada de decisão" (Blackburn, 1997b: 246). Embora isso não implique que devemos 
também renunciar a distingui-las, como tentaremos mostrar a seguir, apresentando o debate entre realismo e idealismo, que se complexifica quando referido às discussões em bioética clínica.

\section{Realismo versus Idealismo?}

Desde pelo menos o surgimento da filosofia moderna, o realismo defende opondo-se ao idealismo - a ideia da "precedência do mundo objetivo sobre a cognição humana, que se limita a fornecer significado ou compreensão a uma realidade autônoma e previamente existente" (Houaiss \& Villar, 2001: 2.391). Nesse contexto, uma metabioética realista parece ser uma contradictio in terminis, pois a expressão confundiria ordens separadas e, portanto, deveria ser evitada, em nome da clareza conceitual e discursiva. Entretanto, a expressão será aqui mantida, pois o próprio significado do termo realismo não é unívoco, visto que "varia com o contexto em que é usado" (Mautner, 2010c: 632), devendo-se, portanto, adjetivar a palavra (neste caso um substantivo) para se obter um sentido mais preciso e que se refira a tipos de objetos e de problemas específicos, como tentaremos mostrar a seguir.

\section{Concepções de realismo e idealismo}

Quando se pensa em uma tipologia dos realismos existentes, pode-se falar, por exemplo, em realismo ontológico (ou "teoria acerca do que há"); em realismo conceptual (referido à "tese de que os universais existem independente e objetivamente, não devendo a sua existência aos particulares individuais de que são atributos, nem ao facto de serem concebidos por uma mente" ${ }^{\prime \prime}$; em realismo epistemológico (ou "tese de que existe um mundo independente da mente [e que] na percepção captamos mentalmente qualidades e objetos que fazem parte do mundo"); e, também, em realismo moral, entendido como teoria segundo a qual "há factos morais independentes das nossas crenças ou atitudes", que são "independentes da vontade de legisladores divinos ou humanos", podendo se referir também a uma "perspectiva realista do caráter e conduta humana" (Mautner, 2010c: 632-633).

Na teoria do conhecimento, os termos realismo e idealismo são associados ao debate sobre a diferença entre o mero pensar - considerado característica 
do idealista - e o conhecer (entendido como "ato de apreensão de um objeto pelo intelecto") realista. Pode-se, portanto, dizer que "a maior diferença entre o realista e o idealista é que o idealista pensa e o realista conhece", visto que "para o realista, pensar [é] ordenar conhecimentos ou refletir sobre seu conteúdo [e ele] nunca teria a ideia de considerar o pensamento como o ponto de partida de sua reflexão, pois, para ele, um pensamento só é possível onde há, antes, pensamentos", ao passo que o idealista, visto que "parte do pensamento para ir às coisas", nunca poderia saber "se aquilo do qual parte corresponde a um objeto, ou não" (Gilson, 1935: 88).

Mas já houve, em filosofia, um sentido contraintuitivo e praticamente oposto ao sentido empirista de realismo, pois o que constituiria o real seriam as ideias graças às quais elaboramos nossa relação (simbólica) com o mundo, não as coisas às quais nossas simbolizações cognitivas se referem. Por exemplo, no realismo absoluto do platonismo defendia-se a concepção da "existência transcendente e primordial das ideias gerais ou universais, cujas cópias [seriam] os objetos materiais e sensíveis da natureza". Na mesma direção, a doutrina medieval defendia a realidade dos assim chamados universais, que teriam existência anterior ao surgimento da consciência humana e seriam, portanto, autônomos, isto é, "desligados dos objetos particulares e concretos" (Gilson, 1935: 88).

Tais exemplos do debate filosófico parecem nos mostrar que

não se deveria crer que os filósofos têm sempre ideias muito precisas quando falam de 'realismo' ou quando se dizem 'realistas' [e] mesmo quando têm ideias suficientemente precisas, não é seguro que tenham algo em comum, [embora] esse tipo de dificuldade nunca tenha desencorajado os filósofos que têm tentado, apesar de tudo, propor características globais ou gerais do realismo, [pois] em muitos casos, o que eles parecem ter em vista [é] a ideia de que o que é verdadeiro ou o que existe poderia muito bem ser independente (ou mais ou menos independente) das nossas crenças mais bem justificadas, de nossas preferências mais razoáveis, de nossas teorias mais refinadas e nossos métodos de investigação mais arrojados. (Ogien, 2006: 948-949)

Assim, essa falta de univocidade semântica do termo realismo e a possível indistinção do seu oposto, idealismo - como na doutrina platônica, em que as ideias "são [consideradas] mais reais que os seres individuais e sensíveis, 
que são apenas seu reflexo e imagem" (Lalande, 1972a: 891) -, não impedem que se pense também em alguma forma de realismo aplicada à problemática ética e bioética. É o que veremos ao tratar da possibilidade de um realismo ético (e bioético) na bioética clínica, sobretudo tendo em conta que esta se refere a práticas concretas envolvidas em conflitos e dilemas morais entre atores sociais em interação, como podem sê-lo médicos (ou outros profissionais da saúde) e pacientes.

Outra justificativa para assumir uma postura realista diante da problemática da bioética clínica (e da ética aplicada ou ética prática em geral) pode ser a de que nas próprias ciências humanas já existem um realismo mental e um realismo sociológico. O primeiro defenderia a realidade de estados mentais (como pensamentos, crenças, desejos e intenções), atualmente estudada, sobretudo, pelas neurociências; e o segundo, a realidade dos fatos sociais, em princípio não redutíveis aos primeiros, mas também, em muitos casos, inseparáveis destes, uma vez que os fatos sociais têm a ver com agentes sociais, seus comportamentos e suas percepções. Portanto, pode-se falar em "concepção fraca da objetividade dos fatos sociais", a qual "admite fatos sociais objetivos sem pagar o preço de uma ontologia extravagante", pois considera que "tais fatos têm uma espécie de influência sobre nossas crenças e nossas ações" (Ogien, 2006: 950).

\section{Metabioética realista?}

Com relação à pertinência de se falar em metaética realista e, especificamente, em metabioética realista, uma indicação parece ser dada pelo novo pragmatismo. Resultante da interação do pragmatismo tradicional - "crença de que o significado de uma doutrina é idêntico aos efeitos práticos que resultam de sua adoção" (Blackburn, 1997c: 307) - com a filosofia analítica - processo de análise da linguagem e dos conceitos utilizados pela reflexão filosófica -, o novo pragmatismo é concebido como uma forma de saber resultante da relação entre nossos pensamentos e a realidade objetiva constituída por nossa práxis, ou seja, resulta do vínculo que podemos estabelecer entre conhecimento e ação. Algo, de fato, já percebido, por exemplo, por Kant, que havia postulado o primado da razão prática, referida à capacidade de produzir objetos correspondentes às representações da razão pura (ou teórica) e referida 
também aos objetos do processo de conhecer, pois, uma vez que "na inteligência comum da humanidade, a faculdade de julgar em matéria prática é em todos os aspectos superior à faculdade de julgar em matéria teórica", pode-se dizer que "a filosofia definida como doutrina da sageza apresenta sobre a filosofia como ciência especulativa a vantagem de não ser derivada de mais nada além do puro poder prático de razão, ou seja, da moral" (Kant apud Guillermit, 1995: 16). Em outros termos, a razão prática "não dita apenas ações particulares, governando antes as relações entre ações, desejos e crenças - tal como a razão teórica governa as relações entre crenças e requer algum material específico para sobre ele trabalhar" (Nagel, 1999: 128, destaque do original).

Esse vínculo entre conhecer e agir é possível graças ao papel dos valores em nossa compreensão das verdades lógicas e dos fatos científicos. Isto é, devido à "concepção pragmática da ação" que reúne na abordagem da experiência humana, os "fatores lógico-formais" e os "fatores empírico-materiais" para poder "ultrapassar os esquemas binários" herdados do cartesianismo, uma vez que "a ação não tolera o dualismo entre interesses materiais e valores" e porque "os valores estão incorporados na dimensão racional da ação e governam estratégias para a realização dos interesses materiais" (Calcaterra, 2011: xv).

Uma ajuda para superar o dualismo parece vir do fato de o novo pragmatismo tentar ultrapassar também a posição tradicional da filosofia analítica com relação ao estudo da linguagem, que desconsiderava a sua dimensão performativa (a qual relaciona esquemas conceituais e conteúdos empíricos, isto é, que faz o que diz fazer) e julgava "fatos e verdade como reais, ao passo que os valores seriam meramente emocionais e relativos" (Cormier, 2011: ix).

Um claro exemplo dessa posição pós-dualista do neopragmatismo nos é dado pelo filósofo norte-americano Hilary Putnam, quando destaca o que chama de "colapso da dicotomia entre fato e valor" (2008: 17), tentando mostrar que o conhecimento de fatos sempre pressupõe um conhecimento de valores - o que tornaria fatos e valores inseparáveis - e que os significados envolvidos em "nossas palavras não estão simplesmente no nosso cérebro, sendo antes funções da história das nossas interações com a totalidade do meio ambiente, tanto físico quanto social" (Putnam, 2010: 617). Tal raciocínio 
implicaria, portanto, tentar superar a tradicional dicotomia fato-valor, herdada de uma linha de pensamento que começa com David Hume (1711-1776), se desenvolve com o positivismo lógico e nos impediria de "ver como a avaliação e a descrição estão interconectadas e são interdependentes", que "a própria ciência pressupõe valores" e que os próprios "valores epistêmicos (coerência, simplicidade e similares) também são valores e estão no mesmo barco com os valores éticos, no que diz respeito à objetividade". Em suma, Putnam tenta mostrar que a relação entre fatos e valores não é de separação (como pretende a Lei de Hume), mas de imbricação, pois "um fato é algo que corresponde a uma impressão dos sentidos", e "o conhecimento dos fatos pressupõe o conhecimento de valores" (Putnam, 2008: 14-15, 47, 181).

É com base nessas considerações críticas que podemos abordar a proposta de um realismo na bioética clínica, que veremos a seguir.

\section{Realismo Ético na Bioética Clínica?}

Uma abordagem realista da problemática da bioética clínica (do grego klinikos, referido ao "médico que visita o doente", de klinê, "leito") (Bloch \& Von Wartburg, 1968: 137) é compreensível e justificável. Compreensível porque a problemática da bioética clínica se refere a um conjunto de "atos, fatos e instituições" que se relacionam necessariamente com um "particular concreto" chamado paciente, o qual pode ser entendido como "ente real, concreto e individual onde se manifesta, produz e origina a doença" (Morales, 2008: 74-75). Ademais, pode-se dizer que uma abordagem realista da bioética clínica é justificável com base nas próprias características da primeira ética profissional conhecida, como foi provavelmente a própria ética aplicada dos médicos, norteadora de seu agir profissional e conhecida, historicamente, como ética hipocrática.

De fato, desde o século $\mathrm{V}$ a.C. os médicos partilham uma deontologia (ou ciência dos deveres) que é aplicada aos atos de sua profissão, conhecida como deontologia médica. Tais deveres estão contidos no Juramento de Hipócrates, que compromete o médico a atuar em prol da saúde do doente sob sua responsabilidade e permanece "a referência deontológica fundamental até o século XX" (Hottois, 2001a: 262). Parece, portanto, justificado pensar em um 
realismo da própria ética médica como um todo, inclusive a bioética clínica, em razão das próprias características de sua prática, inseparáveis dos valores que a orientam e da justificativa que a acompanha, que poderá ser cogente ou não e, portanto, justificada ou arbitrária.

\section{'Realismo' metaético?}

Mas dizer que a ética lida com alguma forma de realismo não implica necessariamente dizer que esse realismo constitua também a característica daquela forma de saber teórico conhecido como metaética e considerado uma parte da ética como um todo. Pelo menos se entendermos - como já vimos no início deste ensaio - a metaética stricto sensu, considerada como uma "atividade de segunda ordem em que se investigam os conceitos e os métodos da ética", sem nos preocuparmos diretamente com os problemas práticos envolvidos, ditos de primeira ordem e que concernem "ao que devemos fazer e a como devemos nos comportar" (Blackburn, 1997b: 246). Ou seja, se mantivermos afastado do trabalho analítico qualquer aspecto que possa ser inscrito na categoria chamada realismo, e conservando, portanto, não só uma distinção lógica, mas também uma separação entre problemas de primeira ordem e problemas de segunda ordem, isto é, entre problemas referentes a fatos reais e problemas referentes a representações de fatos, que chamaremos de teóricos (ou logoteóricos), para distingui-los dos problemas práticos (ou técnico-práticos).

Entretanto, essa distinção entre atividades de primeira ordem e atividades de segunda ordem não necessariamente deve ser acompanhada de uma separação entre ordens distintas, pelo menos se entendermos a metaética como um estudo filosófico mais amplo da moralidade, não reduzido à análise conceitual e metodológica, mas que considere também os aspectos referenciais e, sobretudo, os aspectos pragmáticos da linguagem da ética. Um exemplo desses aspectos são os próprios enunciados morais que, como atos linguísticos, têm, além das dimensões denotativa e conotativa, uma dimensão pragmática, graças à qual os enunciados morais se tornam inseparáveis dos referentes (ou fatos) que os atos linguísticos indicam (como podem ser os juízos de aprovação ou recusa sobre determinado comportamento).

Essa dimensão pragmática da metaética deve, por sua vez, ser distinta em outros tipos de estudos dos fatos morais, como aqueles feitos pelas ciências 
humanas e sociais (CHS) - por exemplo, a sociologia, a antropologia, a psicologia (e a psicanálise), a linguística (e a semiótica) - e, eventualmente, pela biologia entendida em seu sentido amplo. A biologia, nesse caso, é compreendida como uma biologia humana ampliada que contempla as antigas categorias de vida, indicadas pelas palavras gregas zoé e bíos, e integra à biologia tradicional as competências cognitivas e técnicas, as quais, vistas como característica ou qualidade emergente do próprio processo evolutivo, remetem ao saber-fazer biotecnocientífico (Schramm, 1996).

Pode-se, portanto, dizer que uma metaética extensa se torna possível quando se parte do pressuposto de que a reflexão filosófica tem preocupações não somente analíticas, como aquelas da metaética tradicional, mas também práticas, como aquelas da ética aplicada e da bioética, nas quais (como já vimos) vige, sobretudo, a razão prática. Isso faz com que entre a metaética e as CHS haja uma espécie de denominador comum, ou (se preferirmos) uma condição de possibilidade para que as várias disciplinas que surgiram historicamente emancipando-se dessa sua alma mater - representada pela filosofia - possam entrar em um tipo de relação empática, isto é, respeitando suas diferenças e pertinências respectivas, mas sem renunciar ao diálogo, quer na forma da interdisciplinaridade (a interseção de disciplinas), quer naquela da transdisciplinaridade (superação das fronteiras disciplinares, situando os estudos "ao mesmo tempo entre, através das diferentes disciplinas e para além de qualquer disciplina") (Catellin, 2014: 210, destaques do original). Em suma, de um ponto de vista pragmático, os problemas metaéticos não são mais necessariamente uma forma de saber separada dos problemas práticos estudados pelas CHS. Ademais, com base nessa concepção ampliada de metaética, não podemos dizer se um enunciado moral é correto ou não, se é racional ou não, e nos comprometermos a agir moralmente sem analisar "se as convicções morais das pessoas são corretas ou cogentes" (Copp, 2006: 6).

Assim, pode-se dizer que a separação (que acompanha a distinção humeana entre fatos e valores na metaética stricto sensu) ${ }^{1}$ é pelo menos questionável,

\footnotetext{
' De fato, a Lei de Hume proíbe a inferência, no campo da moral, daquilo que "deveria ser" a partir daquilo que "é" (Hume, 200I: 509). Essa distinção é diferente daquela introduzida por Moore, que se refere não tanto a deveres (abordados pela deontologia), mas a valores como o Bem (abordados pela axiologia), e denominada pelo autor de falácia naturalista (Moore, 1999).
} 
pois em uma caracterização da metaética em sentido meramente lógico-formal e semântico (certamente indispensável para analisar a linguagem moral) se esquece que os significados da linguagem dependem do uso que deles é feito nos vários jogos de linguagem existentes e que atuam nas formas de vida envolvidas. Esquece-se que os problemas da teoria moral são inseparáveis "dos problemas de descrição das ações, das intenções, das motivações, dos traços do caráter", e que tais vínculos implicam "novas tarefas para a metaética", como a fundamentação e justificação dos princípios, das normas e dos valores morais (que é um problema epistemológico), ou a indagação ontológica e metafísica sobre a natureza dos valores e normas morais:

hoje, metaética é uma categoria da qual os filósofos morais se servem utilmente para qualificar a reflexão crítica que tem por objeto a teoria ética considerada na multiplicidade das suas expressões, inclusive suas referências, implícitas ou explícitas que sejam, de caráter antropológico e metafísico. (Da Re, 2006: 7.339-7.341)

\section{O retorno da filosofia prática}

Feitas essas considerações epistemológicas e metodológicas sobre a pertinência de se aplicar um ponto de vista realista não somente à ética (e à bioética), mas também à metaética (e à metabioética), pode-se acrescentar que, no século XX, uma forma de realismo - que pode ser chamada de realismo moral, pois "afirma que a ética é, ou pode ser, objetiva" (Brink, 1997: 1.261) se manifesta naquele movimento cultural caracterizado pelo retorno do "interesse pelos problemas concretos (...) sob a denominação applied ethics, ou filosofia prática" (Durand, 2003: 73). Esta, a partir dos anos 1960, tenta ultrapassar a antítese entre cultura científica e cultura humanista, que havia sido incorporada pela tradição da filosofia analítica anglo-saxã, a qual produziudurante a primeira metade do século passado - a caixa de ferramentas conhecida como metaética. A metaética será, contudo, entendida stricto sensu como atividade de segunda ordem, isto é, como "análise teórica dos conceitos fundamentais e dos pressupostos ideológicos, independentemente de toda concepção ética particular", ou como "análise do discurso ético [e do] sentido das proposições morais, sem implicação no plano axiológico" (Durand, 2003: 76). E tudo isso sem entrar no mérito das questões pertinentes, referentes às experiências morais concretas, das diversas visões éticas em conflito entre si, e das 
questões da ética normativa, não necessariamente separadas entre si devido a "possíveis comistões com a práxis" (Da Re, 2006: 7.341).

A discussão teórica em ética, elaborada na primeira metade do século $\mathrm{XX}$, se concentra, sobretudo, no problema da relação entre moral e ética, entendendo esta como estudo (ou ciência ou discurso de segunda ordem) da primeira. Isto é, considerando que a principal função da ética seria o esclarecimento dos conceitos utilizados pelas doutrinas morais existentes, assim como uma análise crítica desses conceitos empregados nas argumentações e justificativas morais que leve em conta o seu caráter (de fato uma pretensão) prevalentemente doutrinário.

Historicamente, tal debate teórico é inseparável do contexto cultural em que emergiu a própria metaética, profundamente marcado pelo positivismo e pela exigência de que a própria ética adquirisse estatuto de cientificidade ou pelo menos de objetividade em seus enunciados e deixasse de ser considerada uma construção arbitrária. Ademais, devemos lembrar que, historicamente, a metaética pode ser vista como uma resposta às "tendências que negavam a possibilidade de uma ética normativa e limitavam o papel da ética a ser uma filosofia da moral" ou - de maneira talvez mais modesta - como uma ferramenta reservada ao mero "mundo dos discursos" (Cremaschi, 2005: 12).

É esse conjunto problemático e problematizador que constitui, desde então, o âmbito analítico e crítico em que a metaética de fato atuou antes da transição paradigmática em ética, representada pela emergência da ética prática no começo da segunda metade do século XX. Tal emergência pode ser interpretada como uma transição da problemática e do método da guinada linguística (linguistic turn) (Rorty, 1967), essencialmente preocupada com uma "gramaticalização da experiência" (Gargani, 2006: 9.840), para a guinada pragmática (pragmatic turn), mais preocupada com as práticas sociais e a temática ética e política (Bernstein, 2010). Ou como uma tentativa de construir um "ponto de vista construtivista", capaz de conciliar exigências pragmáticas e a "mentalidade relativista gerada pela crise dos modelos tradicionais de racionalidade", resultantes da filosofia cartesiana, isto é, como um exercício capaz de conciliar a "falibilidade das conquistas teóricas e sua crença na possibilidade de construir hábitos lógicos e comportamentais corroborados 
pela concordância intersubjetiva no raciocínio sobre a experiência" (Calcaterra, 2011: xvi).

Apesar da justificativa aqui apresentada, uma abordagem realista em metaética continua parecendo paradoxal, pelo menos se a entendermos como já vimos - de acordo com as exigências de sua concepção stricto sensu: como atividade racional de segunda ordem que consiste na investigação sobre os conceitos morais envolvidos, seus conteúdos e suas relações lógicas na argumentação moral, a qual deveria ser metodologicamente distinta e separada dos problemas práticos, chamados de primeira ordem, que se referem, por um lado, a tomadas de decisão em situações conflituosas concretas e, por outro, aos princípios ou valores morais a serem adotados para agir corretamente. Por exemplo: para tentar resolver conflitos e evitar suas consequências danosas, como pode ser o caso do sofrimento evitável, abordado, inclusive, pela bioética clínica. Nesse sentido tradicional, o campo da problemática metaética (ou de segunda ordem) não poderia ser confundido com aquele dos problemas éticos práticos (ou de primeira ordem), e tal preocupação em distinguir âmbitos de pertinência diferentes constituiria uma espécie de "higiene lógica" (Palombi, 2003: 60). Essa distinção se aplica também à emergente bioética, como veremos a seguir, apresentando a dialética construída entre as assim chamadas filosofias analítica e continental.

\section{A Superação Construtivista da Oposição entre Analíticos e Continentais em Bioética}

O contexto cultural em que se gesta a bioética na segunda metade do século XX é marcado por um aparente paradoxo entre os chamados analíticos e continentais em filosofia (D'Agostini, 1997) - que pode ser exemplificado pela oposição aqui estabelecida entre metaética stricto sensu e metaética lato sensu. Para Franca D'Agostini, a filosofia analítica se caracterizaria por "fazer uso de formalismos e linguagens 'disciplinadas', requerer argumentações [que sejam] controláveis, e tender, portanto, a tratar questões bastante circunscritas", tendo "um corte prevalentemente conceitual, ou temático" e que "não se ocupa tanto de autores e de textos, mas de conceitos e problemas"; ao passo que a filosofia continental exclui "o uso de linguagens formalizadas", faz uso de "argumentações nem sempre exatamente reconstruíveis", adotando 
um "recorte prevalentemente histórico, ou textual", referindo-se "a autores, a textos, a fases particulares da história do pensamento, a grandes unidades histórico-conceituais (a ontologia antes e depois de Platão; o acontecimento da modernidade; a racionalização na idade moderna etc.)" (D'Agostini, 1997: 58, destaque do original).

Mas tal paradoxo pode ser evitado se abandonarmos o sentido restrito de metaética para subsumi-lo ao sentido amplo (ou lato sensu) aqui indicado pelo adjetivo realista. Como já vimos, essa atitude é, no fundo, um questionamento da própria separação entre problemas de primeira ordem e problemas de segunda ordem, questionamento que pode ser feito também se adotando uma postura metodológica construtivista, a qual se diferencia da tradicional postura - chamada analítica - que é entendida, stricto sensu, não somente como produto de um ponto de vista preocupado em saber fazer distinções, mas também como uma atitude preocupada com a separação dos vários tipos de problemas relativos à ética, a começar pela dissociação entre os problemas de primeira ordem e aqueles de segunda ordem. Entretanto, essa distinção-separação entre ordens e campos problemáticos acaba separando também os problemas de forma (ou de linguagem) daqueles de conteúdo (ou de sentido), que são considerados inseparáveis entre si pelo menos desde o surgimento das ciências das linguagens contemporâneas.

De fato, a distinção-separação atinge a própria relação entre linguagem e problemas concretos, os quais - como veremos - remetem à relação entre enunciados e fatos (ou referentes). Contudo, tal separação, implicada pela metaética tradicional, talvez seja metodologicamente justificada devido à preocupação (positivista e neopositivista) de transformar a filosofia moral (e a filosofia como um todo) em filosofia científica, fundada na lógica e nos "resultados das ciências naturais e exatas", separada de - e até oposta a - uma filosofia "'humanista', que considera determinante a história e pensa a lógica como 'arte do logos' ou 'disciplina do conceito'", e não como mero "cálculo ou computação" (D’Agostini, 1997: 2).

Essa "antítese entre analíticos e continentais reproduz no interior da filosofia a antítese entre cultura científica e cultura humanista", o que constitui uma "turbulência interna da qual a filosofia (...) nunca se libertou 
completamente" (D'Agostini, 1997: 2). Trata-se, em substância, de uma herança da oposição tradicional entre empirismo e idealismo do século XIX, mas que o construtivismo, por um lado, e a hermenêutica e a fenomenologia, por outro, tentaram superar, afirmando, por exemplo, que a distinção não é necessariamente uma separação stricto sensu entre metaética e aquilo "que devemos fazer e como devemos nos comportar" (Blackburn, 1997b: 246).

A abordagem construtivista tem mostrado que, na própria elaboração e produção do conhecimento científico, "não se pode separar o conhecimento construído das finalidades ligadas à ação de conhecer" e que isso depende do "caráter teleológico do julgamento, logo do raciocínio, isto é, [da] capacidade do espírito humano cognoscente de elaborar fins (tells), em relação aos quais se exercerá em seguida a razão (a faculdade de julgar)". Por essa razão, pode-se afirmar que "o ato cognitivo inteiro tem um caráter intencional e, portanto, finalizado" e que "o conhecimento construído por esse ato é ele mesmo finalizado e depende da finalidade que estava na base de sua explicitação" (Mucchielli \& Noy, 2005: 31).

Em outros termos, esse aparente paradoxo - indicado pela antítese entre analíticos e continentais - pode ser superado se estabelecermos uma relação entre o mundo das ideias e o mundo dos fatos que não seja de tipo meramente contrastivo, pois ambos os mundos estão de fato referidos a um terceiro mundo, o qual, por sua vez, se refere ao universo dos valores morais existentes no mundo - que podemos, então, chamar de mundo dos valores - e que são objeto de estudo da própria ética. Ou seja, podemos pelo menos contornar o paradoxo se pensarmos na possibilidade de uma concepção de metaética mais ampla, ou complexa, ainda baseada no método de análise chamado análise conceitual. Esta, considerada necessária à identificação clara dos problemas em pauta, ao lidar com os objetos tradicionais da metaética - essencialmente lógico-formais -, tenta contextualizá-los e integrá-los entre si num todo. E deve, por isso, necessariamente lidar com problemas inerentes a qualquer tipo de linguagem humana, que, além de algum tipo de articulação com o real (dado pela referência), tem patamares distintos - mas não separados - que se entrelaçam num jogo de linguagem e se relacionam - para que haja sentido com o próprio real. 


\section{A necessidade de uma 'análise conceitual'}

Tanto a filosofia da linguagem quanto a psicanálise freudiana mostram que a linguagem tem uma estrutura de superfície "que pode esconder uma lógica profunda, o que pode nos enganar quanto a essa estrutura" (Blackburn, 1997d: 149). Por sua vez, a análise conceitual, entendida como "o processo (ou o seu resultado) de explicar um conceito, uma crença, uma teoria etc., chamando a atenção para os seus constituintes, os seus pressupostos, as suas implicações etc., [que] pode por sua vez servir [para] uma avaliação crítica" (Mautner, 2010d: 57), pode ser vista também como uma tarefa da metaética tradicionalmente entendida, pelo menos se compreendermos esta como uma "investigação teórica a respeito da metodologia e do universo conceitual da ética" (Houaiss \& Vilar, 2001: 1.907).

Mas a metaética pode ser entendida também - em sua nova versão realista como parte de um conjunto mais amplo: como uma reflexão filosófica sobre o que a ética faz e deveria fazer, sobre as razões e as linguagens envolvidas, destacando o "significado dos termos morais; [o] estatuto epistemológico do saber prático e [a] possibilidade, ou não, de uma sua justificação racional; [a] natureza dos princípios e dos valores morais", e devendo, portanto, "enfrentar questões de caráter: 1) lógico-semântico; 2) epistemológico; 3) ontológico e metafísico" (Da Re, 2006: 7.339).

A abordagem realista da ética, aqui delineada, pretende justamente considerar, com a devida atenção, essa lógica profunda inscrita na própria linguagem - inclusive na linguagem moral -, por considerá-la inseparável de uma análise conceitual que tenha uma relação de referência com o mundo e que deve, por isso, não só analisar, mas também situar-se na conflituosidade constitutiva das inter-relações que se dão nas sociedades humanas. Mas tal lógica deve, necessariamente, ser confrontada com o real, entendido como aquilo que em princípio existe independentemente do pensamento humano e suas construções ideais sobre ele (que podem muito bem ser também ilusórias e não dar conta dele).

Entretanto, se não quisermos abandonar o campo da metaética e suas contribuições ao desenvolvimento de uma ética crítica, esse realismo aplicado ao fenômeno da moralidade não deve ser entendido tanto em seus aspectos 
ontológicos ou metafísicos (que se referem àquilo que existe e pode ser em princípio analisado cientificamente ou àquilo que estaria por detrás ou além daquilo que aparece), mas em seus aspectos epistemológico-metodológicos. E isso por considerarmos que "os cânones do raciocínio moral constituem um método confiável para conseguir e acrescer o conhecimento moral", visto que seus enunciados podem ser "verdadeiros ou falsos independentemente das nossas opiniões" e porque seria "possível predicar a verdade ou falsidade dos enunciados que contêm avaliações ou apreciações morais" (Schiavello, 2006: 9.476).

Por todas as razões aqui mencionadas (e que certamente mereceriam ulteriores investigações), manteremos a distinção lógica entre primeira ordem e segunda ordem, aplicada aos fatos morais, mas evitando sua separação e admitindo, portanto, algum tipo de vínculo entre metaética e ética aplicada, em substituição à concepção tradicional de metaética, fundada em sua separação da ética substantiva. Esse é o caso do ponto de vista apresentado, por exemplo, pela filosofia realista atual, que pode ser entendida como constituída por um "realismo crítico (...) segundo o qual o nosso conhecimento do mundo exterior sempre envolve um sujeito, um percepto e um objeto" (Mautner, 2010c: 634), e também como "o melhor quadro teórico para colocar a questão das relações entre linguagem, pensamento e realidade" (Benoist, 2011a: 10-11).

Feita essa longa justificativa da pertinência do realismo em ética, abordaremos, a seguir, a pertinência de uma postura filosófica chamada realista e as possíveis relações que se possam estabelecer entre o realismo ético e a bioética clínica. E também o que podemos entender por fatos na bioética clínica graças às ferramentas da metaética amplamente entendida; o contexto da emergência do paradigma da vida no campo das ciências humanas e sociais; as relações entre ética e metaética na história da bioética; a bioética clínica, suas questões metaéticas e metabioéticas e as condições de possibilidade de uma metabioética realista possivelmente atuante.

\section{Pertinência da Postura Filosófica Realista para a Bioética Clínica}

Existem boas razões para pensar que a postura filosófica dita realista é aplicável à problemática da bioética clínica como um todo, pois, nesta, os 
problemas conceituais e semânticos (que são objeto da metaética) têm um vínculo com a facticidade da conflituosidade moral real, abordada pela ética aplicada em geral, e à qual pertence também a bioética clínica - que certamente lida com conflitos de interesses e de valores, como bem mostra o fato de existirem comitês e conselhos de bioética em muitos hospitais, inclusive no Brasil.

A bioética clínica deve lidar, em primeiro lugar, com a conflituosidade real atuante na prática, algo já destacado, em outro âmbito - a política -, pelo realismo político de Maquiavel, o qual enfocava as relações de força mais do que os eventuais pactos (que serão abordados, por exemplo, por Hobbes no Leviatã e por Rousseau no Contrato Social), e representaria "um pensamento radical da existência em sua inevitável dimensão contrastiva" (Esposito, 2010: 50). Por isso, o realismo político deve partir da constatação da conflituosidade real e intrínseca às inter-relações humanas, que se manifestaria inclusive nas relações políticas.

Ademais, a bioética clínica deve lidar com esse real que se manifesta nas situações conflituosas de seu dia a dia, o que leva à necessidade de agentes morais e responsáveis que sejam competentes para lidar com elas. $\mathrm{O}$ todo devendo ser inscrito - hoje em dia - em um contexto complexo que é, ao mesmo tempo, psicológico, antropológico, sociológico, econômico e ecológico; ou seja, tendo em devida conta dimensões não necessariamente compatíveis entre si, como parece mostrar a atual crise de civilização dita global.

\section{A questão do colapso do consenso em campo moral}

Essa crise global parece patente também em campo moral, pelo menos se pensarmos na curta história da bioética, entendendo-a como uma história dos conflitos entre estranhos morais. Estes, como atores morais, não contam com pressupostos éticos comuns para lidar concretamente com a conflituosidade real (Engelhardt Jr., 1996) e se encontrariam, atualmente, na condição existencial atravessada por "uma diversidade moral insolúvel" e marcada por um "colapso do consenso" - o que não permitiria "vislumbrar no horizonte nenhuma solução para nossas controvérsias" (Engelhardt Jr., 2012: 20).

Aqui não aprofundaremos a questão problemática desse possível colapso do consenso - que na prática acabaria por solapar qualquer possibilidade de 
uma bioética capaz de resolver conflitos concretos - e tentaremos focar nossa atenção nas condições de possibilidade para enfrentar essa difícil questão de outra maneira: condições de possibilidade que podem ser vistas naquilo que a bioética faz - ou deveria fazer - com a sua caixa de ferramentas, a qual incluiria a ferramenta que chamamos metabioética.

Mas, para que possam ser conhecidos, os problemas reais e complexos enfrentados pela bioética precisam, antes, ser entendidos e esclarecidos; ou seja - de acordo com uma distinção proposta por Etienne Gilson (1935) -, os problemas devem ser pensados para ser conhecidos. De fato, essa tarefa faz parte das tarefas tradicionais da metaética, a começar pela análise conceitual, que pode ser considerada sua principal ferramenta para uma análise pertinente do discurso moral, entendido, fenomenologicamente, como "a dimensão originária a partir da qual é possível articular a compreensão de qualquer fenômeno cultural e natural" (Palombi, 2003: 32). A comunicação - ou compartilhamento - desse sentido entre os atores sociais em conflito envolvidos, e que queiram chegar pelo menos a um acordo, isto é, ir além (se possível) da mera constatação factual, como pode ser aquela do colapso do consenso, também é uma dessas tarefas.

Em realidade, esse é o principal objetivo, ao mesmo tempo ético e político, do pluralismo, baseado na tolerância, e que surge em época contemporânea a partir do final do século XIX, para permitir o desenvolvimento de

sociedades compostas por indivíduos e grupos livres para não partilhar as mesmas convicções culturais, morais, políticas, religiosas e filosóficas, mas, no entanto, desejosos de viver em conjunto e de, para esse efeito, acordar entre si um conjunto de regras que assegure a viabilidade de sociedades desse tipo. (Hottois, 2003c: 524)

Assim, mesmo admitindo (por absurdo) esse colapso referido ao consenso, isso não impede - como já indicamos - que exista a possibilidade de se encontrarem acordos práticos (ou pragmáticos) entre atores em conflito, pois já o termo, bastante vago, consenso (do latim consensum, que significa propriamente compartir o mesmo sentido), empregado na expressão de Engelhardt "colapso do consenso" (2012: 20), permite pensar (e eventualmente conhecer) tal possibilidade. 
A expressão colapso do consenso pode ser entendida de duas maneiras diferentes. Num primeiro sentido, pode estar referida a uma incompatibilidade a priori entre sistemas morais diferentes e, num segundo sentido, pode ser entendida como incompatibilidade a posteriori. Ou seja, o "colapso" pode ser o resultado de uma incongruência de princípio (ou lógica), pois partilhar o mesmo sentido (como diz a semântica da palavra latina consensus) seria uma condição necessária de um processo comunicativo entre conflitantes. Mas o consenso, embora não dado a priori, pode eventualmente ser construído a posteriori, isto é, no momento do confronto entre sistemas diferentes, e isso para tentar elaborar um sentido compartilhado e considerado necessário para a solução do conflito em pauta. O contrário sendo também possível, pois podemos partir de um consenso e acabar, por alguma razão não conhecida de antemão, num desacordo que indicaria esse colapso do consenso indicado por Engelhardt (2012).

Em outros termos, podemos admitir a existência de um colapso do consenso com relação a crenças, que são construções de primeira ordem (como podem sê-lo as várias crenças morais e as escalas de valores existentes no mundo atual), sem, com isso, sermos obrigados a inferir que exista, consequentemente, o mesmo tipo de colapso entre construções de segunda ordem, que podem muito bem dialogar entre si. Ou seja, mesmo admitindo-se que esse colapso seja algo existindo no real, demonstrável com base na conflituosidade existente (como na guerra), isso não impede a possibilidade de se estabelecer algum tipo de relação, diferente da mera incompatibilidade lógica ou semântica, e que pode ser chamada de pragmática (como os acordos de paz após uma guerra ou os acordos preventivos de uma guerra). Essa pode ser inclusive a tarefa (embora indireta) de uma reflexão crítica sobre os fatos abordados pela bioética clínica que seja mais ampla do que aquela da metaética tradicionalmente entendida, pois uma concepção extensa de metaética permite que esta seja vista como inseparável de seu contexto conflituoso real e das várias tentativas de construir, se não consensos, pelo menos acordos (por exemplo, sobre um sofrimento evitável). Tal pode ser o caso de uma reflexão que parta da análise conceitual dos termos e categorias utilizados, assim como de uma análise lógica dos argumentos em campo durante as deliberações, para tentar identificar o que tanto a linguagem 
do senso comum como as linguagens especializadas (como aquelas das éticas aplicadas) escondem em sua lógica profunda, em suas margens e não ditos, o que deverá ser de fato desconstruído e reconstruído para que a terapia possa funcionar na prática.

Tudo isso pode ser visto como um desafio para a metaética em geral e a fortiori - insistindo na utilização deste neologismo - para a metabioética, entendida como análise de segunda ordem dos enunciados e juízos da bioética e referida ao pluralismo normativo vigente em bioética. Mas pode se tornar - como já vimos - um desafio incontornável se a metabioética for entendida como um campo da ética não somente distinto, mas também separado das relações contextuais e do mundo, as quais participam da criação do sentido, inclusive de tipo moral, no mundo.

No caso específico da bioética clínica, pode-se dizer que o principal objetivo de uma possível metabioética consistiria em uma análise crítica dos conceitos e argumentos envolvidos nos fenômenos morais. Tal análise seria, assim, considerada necessária na procura de solução para os conflitos que podem surgir na prática clínica, a qual pode, assim, ser caracterizada pela qualidade das relações humanas que se estabelecem entre os dois tipos de atores chamados - de acordo ainda com a terminologia de Engelhardt Jr. (1996) agentes e pacientes morais.

\section{A questão da análise racional e imparcial}

Essa qualidade das inter-relações humanas em uma sociedade que se concebe como pluralista depende das tentativas práticas de solução da conflituosidade que, por sua vez, é intrínseca a tais inter-relações.

Nessas tentativas, um dos métodos (ou caminhos) a serem adotados consiste em imaginar um ponto de vista ideal, identificado com um hipotético espectador racional e imparcial, chamado também de observador ideal, tido como supostamente capaz de obter uma avaliação abrangente do todo (e de seu caráter conflituoso) que possa ser considerada objetiva, isto é, livre de preconceitos e das consequências de um envolvimento emocional, não controlado racionalmente, que poderia enviesar o juízo, tornando-o parcial. Foi a consideração dessa possibilidade - como já observamos também para o 
neopositivismo - que levou ao projeto de uma ética objetiva e científica, como aquela visada pela filosofia analítica da primeira metade do século XX.

Se olharmos a história da ética do século XX, esse papel analítico e imparcial parece ter sido aquele da metaética, que pode ser entendida também como uma semiótica das questões de forma e de conteúdo referentes ao uso das ferramentas da ética, visto que uma semiotização desse tipo pretende descrever e entender os conflitos e, mediante esse entendimento analítico - que pode ser compartilhado ou não pelos agentes e pacientes morais -, propor soluções normativas (axiológicas ou deontológicas) capazes de orientar sua solução. Esse poderia ser o papel de uma semiótica da ética - a ser pensada e desenvolvida como uma "ciência do valor" (Fontanille, 2007) - ou, mais precisamente, de uma "semiótica das práticas éticas", interessada mais "em analisar práticas do que textos" e considerando o sujeito humano não mais como mera "posição sintática de uma narrativa fechada", mas sim como "subjetividade plena em formação e que se questiona"; em suma, uma semiótica da ética entendida como uma forma de saber que se ocupa das "relações entre o sujeito concebido como produto discursivo e o sujeito [entendido] como pessoa que age no mundo" (Dondero, 2008: 5).

Entretanto, o propósito neste ensaio é mais modesto, pois aqui pretendemos analisar um aspecto específico dessa problemática complexa, representada por uma possível semiótica da bioética, tentando mostrar - para começar-que tanto o conceito de imparcialidade quanto a justificativa para separar a metaética da ética descritiva e da ética normativa são ainda objetos de controvérsias. No entanto, também cabe mostrar que essa controvérsia pode, de algum modo, ser superada (ou pelo menos contornada), mantendo-se a distinção entre tais âmbitos, sem que isso implique, necessariamente, sua separação, pois tal distinção depende, em última instância, daquilo que entendemos por linguagem, suas características e funções.

Esse percurso possível tem antecedentes, pois tal tipo de procedimento analítico, inseparável de seus desdobramentos práticos, é umas das conquistas da própria filosofia da linguagem - a partir do "segundo Wittgenstein" (Wittgenstein, 1953, 1990), preocupado essencialmente com o papel das atividades linguísticas sobre as ações e as vidas das pessoas - e da linguística do século XX. Esta, pelo menos desde a teoria dos atos de fala de Austin (1962), 
sabe que não há mais consenso sobre a pertinência e legitimidade de separar o significado e o uso da linguagem nos jogos de linguagem adotados, assim como não há mais consenso sobre a "dicotomia entre fatos e valores" (Putnam, 2008), a qual levava não só a distinguir, mas também a separar, descrição e prescrição. E isso é possível porque haveria descrições de fatos que contêm significados morais e avaliações morais que encerram conteúdos referentes a fatos, como pode ser o caso dos nossos juízos referidos aos conflitos morais em que estamos envolvidos. Em suma, nesse contexto realista, a própria metaética parece instada a se ocupar não somente da análise conceitual e da lógica dos enunciados e discursos morais - análise certamente necessária, mas não suficiente, de um fato moral -, mas também da relação entre tais conceitos e os enunciados que os contenham, assim como da relação dessa linguagem com seus referentes concretos, como podem sê-lo os conflitos reais.

Entretanto, relações devem, ainda, ser referidas àquilo que Merleau-Ponty chamou de "a carne" do mundo, entendida "não como fato ou somatório de fatos, mas como lugar de uma inscrição de verdade", em que "meu corpo é feito da mesma carne do mundo [e], ademais, essa carne de meu corpo faz parte do mundo", pois "ele a reflete, ele se apossa dela e ela se apossa dele" (MerleauPonty, 1964: 171, 297, destaque do original). Ou seja, essa "carne" se inscreve no ethos vigente, representado pelas ações e intenções dos agentes morais, assim como pelos motivos e pelas particularidades desses agentes que afetam (ou podem afetar) os pacientes morais - destinatários dos atos dos primeiros -, o que torna os juízos éticos uma espécie particular de fatos. Ademais, não se pode esquecer que tais fatos se inscrevem também - de acordo com o ponto de vista da fenomenologia - no "mundo social prático, onde ocorrem relações intersubjetivas" (Depraz, 1997: 124).

É nessa espécie particular de fatos que se destacam os fatos da bioética clínica, que veremos a seguir, inscrevendo-a em seu contexto cultural.

\section{Os Fatos da Bioética Clínica e seu Contexto Cultural}

Os fatos da bioética clínica podem ser vistos como eventos que se referem à conflituosidade moral "em todos os cenários institucionais" onde se realize alguma prática clínica, e cujo objetivo principal é constituído pela 
"[promoção do] desenvolvimento do campo da ética clínica e assessoria ética", por meio de um "enfoque interdisciplinar". 2

Nessa concepção, ao abordar a conflituosidade moral, relacionam-se essencialmente três aspectos:

1) Um aspecto referente ou fato real, constatável objetivamente e representado pelos conflitos morais reais inscritos nas inter-relações entre médicos (e demais profissionais da saúde) e pacientes (e seu entorno familiar ou comunitário) na prática clínica.

2) Uma competência ética específica, em princípio por parte dos agentes morais que tenham alguma familiaridade com a caixa de ferramentas da ética aplicada e da bioética e as apliquem concretamente, por exemplo, na assessoria em ética (como no caso de um consultor em bioética de um hospital) e na participação em algum dispositivo de ética ou bioética institucional (como membro de um comitê de ética hospitalar, de um conselho ou de uma comissão de bioética ou de um comitê de ética em pesquisa). Tal participação pode ser considerada necessária, por exemplo, quando se trata de resolver, de maneira profissional, conflitos morais que dificilmente podem ser resolvidos espontânea e intuitivamente, isto é, sem um saber específico, como o da bioética, o qual se relaciona - de acordo com as exigências da interdisciplinaridade e/ou da transdisciplinaridade amplamente reivindicadas por bioeticistas - com pontos de vista, paradigmas, métodos e problemas de outras formas de saber e de saber-fazer envolvidas.

3) O contexto antropológico e sociológico de pluralismo moral, supostamente vigente nas sociedades complexas e democráticas contemporâneas, nas quais devem ser enfrentados conflitos de interesses e de valores para que os agentes e pacientes morais envolvidos tentem resolvê-los da melhor maneira possível.

A relação entre essas três dimensões pode ser vista como complexa, pois fatos, competência específica e contexto podem ser distintos - como objetos de estudo de várias disciplinas - mas não separados, porque estão entrelaçados e formam um conjunto em que as três dimensões devem ser pensadas, ao

${ }^{2}<$ www.ethics2012.org.br/conferencias.php>. Acesso em: 9 out. 2013. 
mesmo tempo, como distintas e relacionadas, ou seja, numa espécie de tensão dialética sem fim. Se excluirmos essa tensão dialética entre tais dimensões, teremos inevitavelmente - como pretende Engelhardt (2012) - o colapso de um possível consenso ou acordo. Parece, portanto, que tal dialética demanda uma reflexão crítica sobre os fatos contextualizados, a qual, por sua vez, demanda, muitas vezes, também uma análise conceitual dos termos e categorias utilizados, ademais de uma análise lógica dos argumentos em campo nas deliberações, pois tal análise conceitual serve para pensar corretamente, isto é, para identificar, com clareza, o problema e tentar conhecê-lo em seus aspectos morais pertinentes e, a partir disso, eventualmente resolvê-lo de forma prática mediante algum acordo compartilhado.

Mas essa análise conceitual, como já vimos, é considerada, tradicionalmente, tarefa da metaética, que pode ser entendida - de acordo com o sentido dos dicionários - como:

1) uma "investigação teórica a respeito da metodologia e do universo conceitual da ética, em oposição às reflexões morais que envolvem questões empíricas, como o modo correto de ação ou a reta disposição de caráter no comportamento cotidiano" (Houaiss \& Vilar, 2001: 1.907), isto é, como um discurso de segunda ordem aplicado aos fatos de primeira ordem, representados pelas crenças morais;

2) uma reflexão filosófica mais abrangente e que pode ser vista como distinta tanto da ética descritiva quanto da ética normativa, porque a ética descritiva "utiliza os resultados fornecidos pelas ciências humanas, a antropologia cultural, a etnologia, a sociologia, a estatística etc., para identificar [os] comportamentos considerados de fato justos ou concretamente praticados, ou estabelecidos por determinados códigos morais [em] ordenamentos jurídicos particulares" e a ética normativa se ocupa das "diversas modalidades de argumentação moral e de formulação dos juízos morais, [assim como da] identificação das normas morais" (Da Re, 2006: 7.339).

Entretanto, essa análise conceitual se inscreve-considerada seja no sentido 1, seja no sentido 2 - em um contexto cultural preciso, constituído hoje pela emergência do "paradigma da vida", produto de um "pensamento vivente" 
e resultante do "cruzamento entre vida e história - constituído pela política" e que produziu a biopolítica, entendida como forma de saber que apresenta efeitos performativos sobre a vida humana - pois, graças a tal pensamento vivente, a vida ter-se-ia tornado "objeto de práticas políticas destinadas a transformá-la e, portanto, [a torná-la] inevitavelmente, matéria de conflitos" (Esposito, 2010: 10-11).

\section{O contexto representado pela emergência do paradigma da vida e o caso da Italian theory}

De um ponto de vista crítico, o tipo de relação existente (ou desejável) entre metaética, ética descritiva e ética normativa, assim como a relação específica entre ética e política, inclusive entre biologia, bioética e biopolítica, foi objeto de intensos debates ao longo do século XX (Bazzicalupo, 2010), produzidos no contexto de uma nova guinada epistemológica, representada pela emergência do paradigma da vida. Tal paradigma sucede - mas também integra - os conteúdos da guinada linguística (linguistic turn) da filosofia analítica anglo-saxã do século XX, embasada no paradigma da linguagem, que já havia produzido a linguística geral e a semiótica (ou semiologia) entre o final do século XIX e o começo do século XX, com Charles Sanders Peirce (mais conhecido como um dos fundadores do pragmatismo, entendido como uma filosofia que vincula crenças e ações) e Ferdinand de Saussure (considerado o fundador do estruturalismo, para o qual o sentido dos fenômenos humanos só se dá na estrutura formada por suas inter-relações).

Tais debates apresentaram, inicialmente, um cenário em que se destaca um traço negativo e desconstrutivo, uma vez que a discussão "deve se limitar a desmontar seus conceitos, ao invés de criá-los", e "a tarefa atual da filosofia parece ser aquela, autocrítica, de refutar suas próprias pretensões hegemônicas frente a um Real colocado fora de seu alcance" (Esposito, 2010: 3-12), pois tal desconstrução (ou pars destruens) é considerada condição necessária para uma possível reconstrução por vir.

Esse é, por exemplo, o caso da recente Italian theory, a qual tem uma longa gestação no pensamento da esquerda extraparlamentar italiana e começa nos anos 60 do século XX com o debate entre gramscianos - que salientavam a importância do intelectual dito orgânico - e defensores do operaísmo, os quais 
se distinguiam da figura do intelectual orgânico e interpretavam seu tempo como um tempo de crise e de divisão (Calabrò, 2012). Na avaliação de um dos seus representantes, tal teoria se afirma, em âmbito internacional, no começo do século XXI com a preocupação de "entrar em relação, analítica e crítica, com os traços dominantes do nosso tempo" e sair dos impasses do "pensamento contemporâneo, bloqueado na celebração pós-moderna de seu próprio fim para reencontrar uma alavanca para voltar a funcionar de maneira afirmativa" (Esposito, 2010: 3-12).

Talvez o principal produto desse movimento seja o destaque conferido, no âmbito da política inscrita no mundo vital, à problemática chamada biopolítica. Surgida oficialmente com a metodologia genealógica de Foucault, entendida no duplo sentido de poder de vida e poder de morte, a biopolítica é aplicada tanto às formas de saber-fazer científico, produzidas por "uma transformação na maneira como o próprio corpo é investido pelas relações de poder", quanto às formas de governar a vida das populações e aos dispositivos graças aos quais "o corpo [se encontra] diretamente imerso em um campo político [e] as relações de poder operam uma captura imediata" (Foucault, 1976: 28-30).

O termo governamentalidade foi introduzido por Foucault em 1978 em substituição ao termo poder, para indicar as maneiras de governar constituídas pela

articulação entre formas de saber, relações de poder e processos de subjetivação (...) sobre sujeitos e com a ajuda de saberes [que, no entanto,] permitem que formas dadas de subjetividade ou saberes determinados [funcionem] como resistências a determinados procedimentos de governamentalidade [pois] pode-se resistir a formas de governo [recusando] ser governado desta ou daquela maneira, e opor a formas de saber ou de subjetividade articuladas sobre procedimentos de governo dados outros discursos teóricos ou relações consigo. (Gros, 1998: 84, destaques do original)

Como explicou o próprio Foucault (2004a: 111-112),

[por] "governamentalidade" entendo [em primeiro lugar] o conjunto constituído pelas instituições, os procedimentos, análises e reflexões, os cálculos e as táticas que permitem exercer essa forma bem específica, embora muito complexa, de poder que tem como alvo principal a população, como forma maior de saber a economia política, 
como instrumento técnico essencial os dispositivos de segurança. Em segundo lugar (...) entendo a tendência, a linha de força que, em todo o Ocidente, não parou de levar (...) para a preeminência desse tipo de poder que se pode chamar "governo" sobre todos os outros: soberania, disciplina, e que levou, por um lado, ao desenvolvimento de toda uma série de aparelhos específicos de governo [e por outro lado] ao desenvolvimento de toda uma série de saberes. Por fim, creio que por "governamentalidade" deveríamos entender o processo, ou, de preferência, o resultado do processo pelo qual o Estado de justiça da Idade Média, que se tornou, nos séculos XV e XVI, Estado administrativo e, pouco a pouco converteu-se [em Estado] "governamentalizado".

Historicamente, a gestação da problemática biopolítica, entendida como "a filosofia do progresso positivista [e] como projeto de aplicação da ciência a todos os campos do saber e da vida", se dá a partir da segunda metade do século XIX, que é quando surge também o neologismo biocracia para indicar um "projeto de reorganização social e política baseado nos saberes biológicos, que fornecem normas e princípios para comportamentos racionais e socialmente adequados" (Bazzicalupo, 2010: 23-24).

Mas é a partir de uma desconstrução da própria obra de Foucault que a reflexão crítica da Italian theory é desenvolvida, inicialmente, por Giorgio Agamben, que amplia e problematiza o ambíguo conceito foucaultiano de biopolítica. Para fazer isso, Agamben inscreve o conceito de biopolítica na "dupla categoria fundamental da política ocidental [que] não é aquela amigoinimigo, mas [aquela de] vida nua-existência política, zoé-bíos, exclusãoinclusão", pois considera que a "política existe porque o homem é o vivente que, na linguagem, separa e opõe a si a própria vida nua e, ao mesmo tempo, se mantém em relação com ela numa exclusão inclusiva" (Agamben, 2002: 16).

Em seguida, essa reflexão é desenvolvida por Roberto Esposito (2002), para quem o conceito de biopolítica estaria vinculado de fato ao paradigma imunitário que o precede e que teria grande poder heurístico, pois constituiria "um dos primeiros temas de alcance global na filosofia do novo século" (Esposito, 2010:5) e uma das condições de possibilidade de um "pensamento vivente" capaz de dar conta de uma possível "biopolítica afirmativa". Isso graças à detecção de "um possível dispositivo 'normativo' [capaz de] conjugar as exigências [de] proteção da vida e aquelas da salvaguarda do conflito a ela inerente", 
visto que sem essa salvaguarda não seria possível dar conta do "nó crucial entre proteção e negação", isto é, do fato de que "a vida pode ser protegida contra aquilo que a nega somente por meio de uma ulterior negação" (Calabrò, 2012: 113).

O debate sobre a emergência do paradigma da vida e seus desdobramentos é intenso e contraditório, seja porque tal emergência representaria "uma 'virada', sucessiva àquela linguística" (Esposito, 2010: 10), ocorrida um século antes, seja porque o paradigma da vida já se delineia antes da virada linguística (com Darwin), ou ainda porque, quando surge o pragmatismo norte-americano, com Peirce, James e Dewey, os dois paradigmas passam a coexistir.

Os pragmatistas compartem a ideia de que a filosofia moral é mais um movimento concreto do que um mero conjunto de problemas morais analisados pelas disciplinas da linguagem (e que se indica pelo termo metaética), assim como têm a convicção de que o próprio pensamento produz crenças que se explicitam em regras ou em hábitos que, por sua vez, produzem "os efeitos que podemos conceber como tendo implicações práticas", sendo que a concepção "que temos desses efeitos constitui a totalidade de nossa concepção desses objetos" (Putnam, 1997: 1.180).

Entretanto, aqui não aprofundaremos esse debate. Lembramos apenas que, para alguns, seu principal resultado metodológico foi - apesar da aparente subsunção do antigo paradigma da linguagem ao mais recente paradigma da vida - tornar pertinente "a identificação da especificidade da linguagem moral [que] permite (...) justificar a ética como um saber autônomo", distinto de outros saberes (Da Re, 2006: 7.340).

Com efeito, não é que com o surgimento (ou o ressurgimento) do paradigma da vida desapareça o paradigma da linguagem (como uma apropriação incorreta da terminologia de Thomas Kuhn poderia sugerir), considerando, por exemplo, os dois paradigmas como sequenciais (um paradigma substituindo o outro). Os dois paradigmas de fato coexistem numa longa "transição paradigmática" (que é outra categoria de Kuhn) em que coabitam os dois tipos de saberes, vinculados a tais paradigmas e vinculados entre si. Dito de outro modo, o que parece estar acontecendo atualmente é a possibilidade - aparentemente confirmada por fatos como o crescente interesse pela biopolítica, inclusive no 
campo da saúde - de pensar uma autonomia da ética - supostamente adquirida quando a ética se tornou uma "ciência objetiva" graças à incorporação das ferramentas analíticas das ciências da linguagem. Tal possibilidade parece se dever à relevância - dada pela corrente analítica já a partir dos estudos de Moore (1999), para quem não se podem confundir conceitos e fatos morais, ou aquilo que "é" e aquilo que "tem valor", ou "Bem", sob pena de se cometer uma "falácia naturalística" - atribuída à assim chamada imparcialidade (ou isenção), representada pela imagem do observador racional e imparcial.

Mas essa imagem da imparcialidade, como vimos também, visa à objetividade dos fatos analisados pela componente descritiva e compreensiva da ética, entendida essencialmente como garantia de sua cientificidade. Esta, por sua vez, pode ser vista como condição necessária para a formulação de enunciados morais - ou juízos - que pertencem à sua componente normativa, a qual constitui - para utilizar uma metáfora da linguística aplicada por Saussure ao signo linguístico - a outra face do juízo moral, o qual leva a uma ação que poderá então ser julgada correta ou incorreta "se, e somente se, um observador ideal a aprovar" e que pode ser formulada com a proposição " $P$ é verdadeira se, e somente se, $S$ (um observador ideal) acredita que $P^{\prime \prime}$ (Mautner, 2010e: 539). Em outros termos, o fato moral resultante é constitutivamente coformado - de acordo com a abordagem pragmática já apresentada - pelo sentido resultante de fatos morais objetivos em exame e sua inferência normativa orientadora da ação a ser realizada.

Entretanto, esse tipo de proceder pode ser questionado (como de fato acontece), pois o referimento a um observador racional e imparcial $S$ é considerado, por alguns, como ferramenta necessária para enfrentar os fatos morais concretos (i.e., as práticas e experiências conflituosas concretas) e os vários sistemas de valores vigentes e em conflito entre si, e que, por isso, "requerem um esforço de esclarecimento e de lapidação terminológica" (Da Re, 2006: 7.341). Mas pode ser considerado também como um ponto de referimento demasiado abstrato, pois $S$ não é suficientemente caracterizado para se tornar elemento pertinente e legítimo de um juízo plausível.

O conceito de imparcialidade e sua pertinência como princípio metodológico em ética, assim como o problema da legitimidade de separar ética normativa 
e metaética, caracterizando esta "em sentido puramente formal e de análise semântica" (Da Re, 2006: 7.341), é ainda objeto de discussão dentro da própria filosofia moral de tradição analítica. A partir da segunda metade do século XX, graças às reflexões filosóficas do "segundo Wittgenstein" - que teria produzido em filosofia "uma revolução linguística" ou "guinada pragmática", comparável à "guinada copernicana de Kant" e consistente no método "terapêutico" de "suprimir aqueles problemas filosóficos que se originam de um uso incorreto da linguagem, separado do contexto da vida 'por uma interpretação errada de nossas formas linguísticas'" (Lenk, 2005: 13-14) - e de seus seguidores, como Elisabeth Anscombe ([1958] 1981a), não há mais consenso sobre a pertinência e a legitimidade de separar o significado linguístico e o uso da linguagem nos jogos de linguagem efetivamente em ato. E isso vale, inclusive, nos debates metaéticos da teoria moral (como estamos tentando mostrar). Por isso se costuma - desde essa guinada representada pelo pragmatismo metodológico wittgensteiniano - falar em atos de fala, distinguindo, nestes, atos locutórios ("atos de dizer"), atos ilocutórios ("o que se faz ao dizer") e atos perlocutórios ("o que se produz ao dizer") (Blackburn, 1997a: 29), que podem ser considerados todos como fatos morais, inscritos no real, embora talvez de forma diferente em cada caso, uma vez que o ato de dizer (por exemplo, fazendo uma promessa ou um juramento) se torna um fato que produz um efeito (como realizar a promessa feita) graças ao ato de prometer. Mas isso tem duas implicações existenciais importantes, pois prometer implica se comprometer a cumprir o prometido (sob pena de sanção, inclusive de tipo jurídico no caso do juramento), o que tem consequências práticas para os envolvidos - que podem ser consideradas boas ou ruins por quem as vivencia e, sobretudo, para o espectador dito imparcial.

Tampouco há consenso sobre a pertinência e a legitimidade de separar, no campo da ética aplicada, descrição e prescrição - apesar de devermos em princípio continuar distinguindo-as por uma razão lógica -, visto que existiriam descrições de fatos que contêm significados morais e avaliações morais que encerram conteúdos referentes a fatos que são sempre, como fatos, algo concreto, vivido. Como sentenciou o próprio Wittgenstein (1990: 53), “[são] necessárias, para estabelecer uma prática, não só regras, mas também exemplos. As nossas regras têm lacunas e a prática tem de falar por 
si mesma". Em outros termos, de acordo com essa crítica interna à própria tradição analítica, os problemas abordados pela teoria moral são inseparáveis das descrições das ações, das intenções, dos motivos e dos traços de caráter do agente moral envolvido, o que a torna uma espécie de filosofia analítica dos casos concretos. Sem esquecer "o papel que as emoções têm de nos esclarecer sobre questões de importância ética", podendo-se até dizer que estas teriam "uma função cognitiva", obrigando-nos a "refletir" sobre elas como um componente importante dos próprios fatos éticos (Nussbaum, 2009: xvi).

\section{A necessidade do ponto de vista 'complexo' sobre a moralidade}

Tudo isso que acabamos de apresentar nos leva à proposta de integrar os vários aspectos já descritos no que chamaremos de ponto de vista complexo sobre o fenômeno da moralidade, o qual distingue seus componentes constitutivos, mas sem separá-los.

A principal consequência operativa da aplicação desse ponto de vista complexo, quando aplicado aos fatos morais, é que não podemos mais separar metaética, ética descritiva e ética normativa. Apesar disso, temos que saber pelo menos distingui-las, para não confundir âmbitos que têm também identidade própria (analisada, por exemplo, por disciplinas específicas), embora estejam relacionados entre si devido à vigência do paradigma da vida. Tal paradigma funciona como o contexto real mais amplo em que tais âmbitos específicos se relacionam, e inclui, portanto, os fatos de linguagem, que podem ser considerados elementos do paradigma da linguagem, o qual pode, por sua vez, ser entendido como um subconjunto do paradigma da vida referido ao Homo sapiens.

Assim, parece que, do ponto de vista metodológico, saber "distinguir sem separar, e juntar sem confundir" (Schramm, 2010a: 85) - a imagem síntese do método da complexidade proposto por Edgar Morin (1990: 104), para quem "os princípios do pensamento complexo serão necessariamente princípios de disjunção, de conjunção e de implicação" - é o caminho a trilhar para que se possa combinar: 1) a correta consideração da diversidade tanto das morais como das éticas vigentes (que não representam necessariamente universos coextensivos) que caracterizam o pluralismo contemporâneo de fato; 
2) a sua utilização como dispositivos analíticos e normativos pela prática clínica institucionalizada; e 3) a consideração da bioética clínica como possível foro no qual seja possível construir um diálogo interdisciplinar (ou transdisciplinar, como preferem alguns) entre os vários saberes e as competências específicas envolvidas (Schramm, 2010b).

Esse caminho é certamente um desafio para muitos profissionais, a começar por aqueles que trabalham no campo da saúde e, em particular, da clínica médica. Não somente do ponto de vista da bioética entendida como ética prática, referente à solução concreta dos conflitos do dia a dia da prática clínica, mas também do ponto de vista de uma possível metabioética (utilizando este neologismo que pode certamente ser criticado, como, aliás, já aconteceu com o próprio neologismo bioética nos anos 70 do século XX) (Mori, 1994), entendida como uma metaética aplicada às práticas inscritas num contexto caracterizado pela vigência simultânea do paradigma da linguagem e do paradigma vitalista. O campo complexo da bioética clínica, ao qual a metaética se aplica, inclui - em sua dimensão descritiva e compreensiva - a análise de conceitos, valores e normas envolvidos, assim como uma avaliação da força argumentativa (ou cogência) utilizada para justificar as tomadas de decisão normativas nas situações moralmente problemáticas, e que são vivenciadas nos casos concretos (ou exemplos, na terminologia de Wittgenstein). Ou seja, a bioética clínica utiliza ferramentas dos dois paradigmas.

É esse tipo de desafio que costuma enfrentar a metaética, que, historicamente, pode ser considerada como um dos principais contributos da filosofia analítica ao campo do saber moral, mas que parece instada, atualmente, a se ocupar também das relações entre atos morais, fatos morais e suas representações. Isso se deve à complexificação crescente da problemática ética, a qual adquire cada vez mais uma identidade interdisciplinar (em razão dos vários saberes nela atuantes) e transdisciplinar (visto que seus objetos, representados pelos conflitos, atravessam as fronteiras entre disciplinas).

A seguir, abordaremos, rapidamente, uma parte histórica (ou diacrônica) da relação entre bioética e metaética (aqui também identificada como metabioética) e uma parte sincrônica, relativa à própria pertinência desse tipo de análise conceitual no âmbito da bioética clínica. 


\section{As Relações entre Ética e Metaética na História da Bioética}

De acordo com o bioeticista italiano Maurizio Mori (2011), a bioética, nascida oficialmente nos anos 1970 como a mais importante forma de ética aplicada, parece ter estado na origem de um declínio da tradicional metaética, vigente na ética ocidental desde o começo do século XX - sobretudo na tradição anglo-saxã - e voltada essencialmente para a análise do significado dos termos morais e a avaliação dos argumentos e da lógica subjacente ao discurso moral.

Como explica Mori (2011: 53), os críticos "reconheciam a importância da metaética" e sua "relevante contribuição teórica", inclusive porque instava o filósofo moral a "colocar à disposição [suas] capacidades 'técnicas' adquiridas com o estudo da metaética", o que poderia ter a consequência social desejada de "fazer crescer a consciência civil". Isso porque "a análise lógica dos termos e das inferências, aplicada com rigor aos problemas da vida real", permitiria enfrentar tais problemas com "maior grau de racionalidade e imparcialidade".

Em particular, o reconhecimento da metaética como ferramenta cognitiva pertinente e legítima pressupunha "abandonar a ideia de que a análise dos problemas concretos [implicaria] necessariamente a prevalência das paixões particulares e dos interesses privados sobre a atitude imparcial e racional". Nessa perspectiva, o bioeticista se tornaria um profissional que

teria não somente a oportunidade (a permissão), mas também o dever de examinar sejam problemas gerais (classes de casos), sejam casos concretos específicos (à beira do leito do doente), porque, com seu trabalho filosófico e intelectual, teria dado uma contribuição importante ao crescimento civil da sociedade. (Mori, 2011: 53)

Em termos diacrônicos, pode-se dizer - como já lembramos - que no panorama da história da cultura contemporânea o surgimento da bioética parece marcar a superação da tradicional oposição entre as vertentes analítica e continental em filosofia, denominações que hoje podem ser vistas como a simplificação de um processo complexo de "dois percursos paralelos, que se cruzam às vezes, mas muitas vezes para descobrir novas razões para a divergência" (D'Agostini, 1997: 59).

No primeiro percurso, podemos identificar aquele que corresponde à tradição que começa com o filósofo e psicólogo Franz Brentano (1889), que pode 
ser considerado o criador de uma fenomenologia analítica em que se estabelece uma analogia entre atitudes emotivas conscientes e atitudes intelectuais visto que ambas poderiam ser consideradas corretas ou incorretas do ponto de vista moral - e na qual ele destacava a primazia do intencional (que teria sido negligenciado pela filosofia moderna centrada no intelectual). Tal raciocínio o levou a propor uma ética fundamentada "na analogia que pensa existir entre atitudes intelectuais e emotivas", pois "Brentano considerava que podemos estar imediatamente cientes da correção de algumas de nossas atitudes emotivas, tal como podemos estar imediatamente cientes da correção (i.e., da verdade) de algumas de nossas atitudes intelectuais", sendo que "[em] cada caso, a correção consiste numa relação apropriada ou adequada entre a atitude e o seu objeto" (Mautner, 2010f: 126).

Brentano pode ser visto também como um dos principais representantes da racionalidade analítica porque criticou a obscuridade das argumentações filosóficas dos continentais, crítica que continua com o movimento da lógica formal do neopositivismo, representado por Rudolf Carnap. Este, em um famoso ensaio, propõe um método para superar a problemática metafísica constituída pela análise lógica da linguagem, o qual mostraria que os enunciados metafísicos são, de fato, enunciados sem sentido, pois não poderiam ser nem corroborados nem refutados empiricamente (Carnap, 1932). Tradição que continua com a própria fenomenologia de Edmund Husserl, que adota a tese da intencionalidade da consciência de Brentano e concebe a prática filosófica como "'filosofia científica', fundada na lógica, sobre os resultados das ciências naturais e exatas" (D'Agostini, 1997: 2).

No segundo percurso se situa a tradição continental, que começou com Wilhelm Dilthey, formulador da oposição entre ciências naturais (Naturwissenschaften), essencialmente explicativas, e ciências do espírito (Geisteswissenschaften), basicamente interpretativas. Tal tradição prosseguiu com a hermenêutica de Martin Heidegger e Hans Georg Gadamer, que concebia, ao contrário, a filosofia como "filosofia humanística", isto é, que "considera[va] determinante a história e pensa[va] a lógica como 'arte do logos' ou 'disciplina do conceito', mais do que como cálculo ou computação"; ou seja, que visava à "superação da antítese entre cultura científica e cultura humanista" (D'Agostini, 1997: 2). 
Sem querer detalhar profundamente as diversas avaliações da relação entre discurso filosófico e discurso científico (ou entre analíticos e continentais), aqui parece suficiente lembrar que, atualmente, há relativo consenso sobre o fato de ambas as tradições se referirem - para aceitá-la ou para criticá-la - ao linguistic turn (guinada linguística) em filosofia, representado pela tentativa assinalada por Rorty (1967) - de construir uma teoria do significado e descrever, de forma sistemática, nossos modos de pensar o real. De fato, a guinada linguística - como já vimos falando a respeito da dialética entre paradigma da vida e paradigma da linguagem - "envolve todas as correntes do pensamento contemporâneo", embora esse reconhecimento não impeça que "a questão história-teoria", que se desenvolve no contexto "da antítese entre estilo analítico e estilo continental", permaneça de fato "não resolvida" (D'Agostini, 1997: 15-16).

Assim, nesse movimento, que tenta superar a oposição entre analíticos e continentais e pode ser visto também como uma das características distintivas do pensamento vivente e da vigência do paradigma da vida, parece ser possível inscrever o surgimento da bioética e das éticas aplicadas em geral, ou seja, da "ética prática" (Singer, 1994), a qual pode ser vista como o produto de uma espécie de síntese entre as duas tradições e suas construções. Sem entrar no mérito da pertinência e legitimidade dessa denominação, que compara uma corrente filosófica - representada pela filosofia dita analítica - e uma distinção territorial - referida ao continente europeu - e que refletiria "a tendência, por parte da filosofia analítica, [de] se apresentar como a única verdadeira filosofia nos países de língua anglo-saxônica", a ética prática pode ser vista como um campo tensional em que as duas correntes se relacionam, podendo-se dizer também que a ética prática constitui uma forma particular de "entrelaçamento de teoria e ética" (D’Agostini, 1997: 3, 10).

Entretanto, a declaração de uma superação da dialética entre analíticos e continentais pode ser interpretada - quando comparada com o problema da relação entre a dimensão descritiva e a dimensão prescritiva da ética - como, em realidade, mera - e não necessariamente legítima - redução da complexidade da dinâmica dessa superação, isto é, simples subsunção do aspecto descritivo e compreensivo ao aspecto prescritivo. 
Essa operação lógica subjacente está indicada - pelo menos indiretamente na expressão primado da ética, entendendo-se tal primado como uma espécie de deslocamento em sentido pragmático, sobretudo por quem deve tomar decisões concretas (como na prática clínica), processo inscrito no contexto daquilo que pode ser visto como "uma reabilitação da filosofia contra a razão científico-tecnocrática" (D’Agostini, 1997: 10). Ou, então, como a emergência de um "tipo de argumentação híbrida, que é ao mesmo tempo históricohermenêutica e lógico-analítica" (D'Agostini, 1997: 14). De qualquer maneira, essa questão fica, por enquanto, em aberto, mas poder-se-ia lembrar que, no plano do saber-fazer científico - ou, melhor dito, tecnocientífico - aplicado ao mundo da vida, temos a emergência de outro paradigma, o paradigma biotecnocientífico, que deve ser distinto tanto do paradigma da linguagem como do paradigma da vida, por incluir, em seu conceito, a dimensão técnica ou poiética. Deve-se, portanto, evitar a atribuição de uma conotação vitalista e, assim, todas as consequências indesejadas decorrentes de uma operação desse tipo, como poderia ser aquela da emergência de uma nova dupla problemática: biopolítica e tanatopolítica, como veremos a seguir.

\section{Biopoder, biopolítica, tanatopolítica e paradigma imunitário}

Para Giorgio Agamben (1998), a dupla biopolítica-tanatopolítica remeteria ao conceito de vida nua, entendida como algo ao mesmo tempo natural e capturado por um fora não natural, representado pelo biopoder - já estudado por Foucault (1976) -, que criaria uma relação de inclusão a qual é também, paradoxalmente, de exclusão. Ou seja, a vida nua remeteria a uma concepção de vida que é diretamente política porque, nela, a vida estaria destinada, em última instância, à morte, não por motivos naturais, decorrentes da finitude e da vulnerabilidade humana, mas por questões biopolíticas. E poderíamos acrescentar: biotecnocientíficas - graças às quais a vida desprotegida, de fato vulnerada, se torna a forma de vida dominante, sendo apropriada pelos dispositivos de biopoder e fazendo com que, no plano biopolítico, o estado de exceção se torne regra. Por isso, de acordo ainda com Agamben (1998), a principal consequência política desse movimento - ao mesmo tempo biopolítico e tanatopolítico - seria a indistinção ou um continuum entre democracia e totalitarismo, de onde emergiria um destinatário chamado Homo sacer. 
O outro filósofo da chamada Italian theory, que vem se debruçando sobre a relação biopolítica-tanatopolítica, é o já lembrado Roberto Esposito, para quem, por detrás do paradigma biopolítico, existiria um "paradigma imunitário", que inverteria as "relações de prevalência entre poder e vida" e cuja "metáfora vital [permitiria] a passagem do político ao biopolítico" (Calabrò, 2012: 106). Essa inversão poderia explicar, por exemplo, uma prática e ideologia como a nacional-socialista, na qual "o intento protetor da vida se inverte em seu contrário: na negação da vida", como foi certamente o caso do extermínio em massa representado pela Shoah, guiado pela exigência de proteger "a pretensa qualidade da vida humana mesmo ao custo da morte de 'agentes patógenos' que, se deixados em vida, só poderiam 'infectar' aquela vida que se pretende salvar". E isso aparentemente de acordo com a ética hipocrática, pois "a lógica dos médicos nazistas (...) precisava conservar sempre e de qualquer maneira a parte saudável do corpo político, não permitindo que enxertos ou cruzamentos biológicos pudessem prejudicar ou contaminar a pureza da raça" (Calabrò, 2012: 108).

Feitas essas considerações problemáticas mais gerais, exemplificadas pela dialética entre biopolítica e tanatopolítica - sustentada pelo paradigma imunitário - e que constituem, de algum modo, o contexto discursivo mais apropriado para abordar os problemas concretos e complexos da bioética, assim como suas relações com a biopolítica e a biotecnociência, podemos destacar alguns problemas particulares em suspenso (ou não resolvidos) sobre os tipos de relação existentes (ou que deveriam existir) entre ética e metaética, bioética e metabioética.

\section{Alguns problemas teóricos em suspenso}

O primeiro problema em suspenso é de tipo sociológico e se refere a uma atitude geral de rechaço ou desconfiança com relação à pertinência e à legitimidade da análise metaética, o que pode ser visto também como uma misologia, ou aversão ao conceito. Historicamente, essa misologia se apresenta como produto de uma desconfiança pós-moderna, cujo lema seria, de acordo com Jean-François Lyotard (1979: 8-14), "sejam operacionais, isto é, comensuráveis, ou desapareçam", pois "o saber é e será produzido para ser vendido, e é e será consumido para ser valorizado em uma nova produção; 
nos dois casos: para ser trocado"; ou seja, porque o saber ter-se-ia tornado "a principal força produtiva". Tal atitude seria típica do "homem de ação" e corresponderia a uma "perda de crédito das grandes teorias", o que teria levado a um "reino da afetividade sem conceito", devido "a sua constitutiva ausência de espírito crítico", de fato reduzido "muitas vezes à mera ideologia" (Benoist, 2011b: 40-41).

O segundo problema - aparentemente mais sério do ponto de vista dos desafios à metaética - é epistemológico e diz respeito à relação referencial entre conceitos e objetos, ou - se preferirmos - entre simbólico e real, pois tal relação estaria sempre (ou estruturalmente) marcada por uma falta, visto que "a própria condição do alcance real de nossos conceitos é sua ultrapassagem pelo real", problema para o qual não teríamos solução porque de fato "não temos conceitos" para dar conta de tal ultrapassagem (Benoist, 2011b: 35).

O terceiro problema é de tipo propriamente pragmático, pois se refere à possível e efetiva relação entre conceitos e experiência, uma vez que os conceitos podem não dar conta de toda a experiência que devem e pretendem representar. De acordo com a teoria dos atos de fala, existe o aspecto da ação dos conceitos, diante, por exemplo, da ação da sensibilidade. Mas existe também o problema metaético da legitimidade da noção de conceito ante a noção de sensibilidade.

Tal problema parece patente no caso das normas, em que deveríamos ter presente que:

1) "sempre que raciocinamos podemos errar";

2) "sempre existe conceito onde uma norma é aplicada à experiência";

3) "sobre nossos conceitos pesa, em geral, uma forma de suspeita", pois podemos sempre perguntar se os conceitos utilizados "são capazes [de] atingir o real", visto que "o real nem sempre se apresenta no encontro do conceito que lhe aplicamos, ou tentamos lhe aplicar"; ou seja, porque:

4) "devemos assumir esta possibilidade de que um conceito seja vazio" (Benoist, 2011b: 58-69).

Nesse contexto crítico geral (indicado pela desconfiança dita pós-moderna) sobre o alcance e os limites da metaética, deve-se destacar uma de suas 
ferramentas utilizadas nas tentativas de superar essa desconfiança diante das possibilidades de solução da conflituosidade moral abordada pela bioética, inclusive pela bioética clínica. Trata-se da ferramenta problemática, já lembrada e conhecida como análise racional e imparcial, considerada necessária para se abordar corretamente um conflito concreto, pois ela nos permitiria lembrar que

o conceito implica [sempre] certo distanciamento [e que] sempre existe conceito onde se instaura essa distância lógica, que é aquela que existe entre o verdadeiro e o falso, ou (...) para generalizar (...), inclusive em direção às atitudes práticas em que estas se tornam ações no sentido (...) do correto e do incorreto. (Benoist, 2011b: 70-71, destaques do original)

É esse tipo de questão que a metaética em geral e a análise conceitual de maneira específica pretendem analisar, sendo que ambas podem ser vistas como ferramentas indispensáveis da própria bioética clínica para esclarecer os termos de seus conflitos e dilemas morais - o que poderia ser visto também como condição necessária (embora não suficiente) para resolver um conflito graças a essa consideração analítica e crítica de seus argumentos.

\section{A Bioética Clínica, suas Questões Metaéticas e Metabioéticas}

Quando se integram as dimensões da teoria e da prática na identificação da identidade da bioética clínica, esta pode ser vista como o campo de saberes e de reflexões capazes de detectar, analisar, compreender e tentar resolver os conflitos morais que se dão no tratamento (ou cuidado) individual (ou pessoal) de pacientes. Ou seja, a bioética clínica pode ser conceituada como um campo resultante da inter-relação de "teoria e prática, experiência e reflexão"(Georgetown University Medical Center, s.d.).

Mas a bioética clínica tem um antecedente histórico na forma de ética aplicada chamada "ética clínica", termo utilizado por Joseph Fletcher em 1976 para "designar a prática da decisão clínica em situação problemática no plano moral", que deveria "refletir a natureza específica da bioética, aplicada na clínica ou em situações centradas no paciente". ${ }^{3}$ Em realidade, a bioética clínica pode ser vista como a parte da bioética ou - como preferem alguns -

${ }^{3}<$ www.jiffnotes.com/a_study_guides/book_notes/ewb_05/ewb_05_02192.html>. Acesso em: 10 out. 2013. 
uma das bioéticas (Neves \& Lima, 2005) referentes à moralidade de um conjunto bastante vasto de práticas, que se referem ao tratamento ou cuidado de pacientes e devem ser capazes não somente de resolver em termos práticos um conflito, mas também de abordá-lo teoricamente para justificar a decisão pela qual se pretende resolvê-lo. Ou seja, a bioética clínica deve saber identificar e analisar conceitos e argumentos envolvidos nesse tipo específico de interrelação, inscrita na conflituosidade social, que se estabelece entre agentes e pacientes morais, isto é, entre os autores dos atos e seus destinatários (diretos ou indiretos).

Assim, a bioética clínica - como qualquer âmbito da bioética - se depara necessariamente com questões conceituais e dúvidas acerca da decisão correta a ser tomada numa inter-relação, como a que se estabelece, por exemplo, entre médico e paciente, que deve em princípio ser horizontal e dialógica (ou, melhor dito, horizontal porque dialógica), evitando, portanto, seja atitudes autoritárias, seja atitudes paternalistas. E isso devido a seu objetivo principal, que consiste em resolver conflitos no âmbito da prática clínica graças a ações de tipo inclusivo e comunicativo entre pares - e que não pode se dar em uma relação hierárquica autoritária ou paternalista em que o médico toma a decisão que considera correta, sem a participação ou pelo menos o consentimento de seu paciente. Assim, pode-se dizer que a bioética clínica lida com conflitos morais que devem em princípio ser resolvidos consensualmente, ou - tendo em conta as ambiguidades e dificuldades do termo consenso - por negociações e acordos. E isso respeitando os interesses moralmente legítimos envolvidos e a cláusula de que os participantes do acordo sejam suficientemente racionais ou razoáveis. Ou seja, participantes suficientemente imparciais e não impelidos por emoções incontroláveis ou crenças inquestionáveis na escolha da melhor solução possível do conflito em situações em que haja diversas concepções do correto e incorreto, como pretende indicar o termo pluralismo moral aplicado às sociedades complexas contemporâneas.

Entretanto, aqui surge o problema conceitual e lógico dos dilemas morais enfrentados na prática clínica, conflitos de difícil solução (quando não impossíveis de resolver sem alguma arbitrariedade) por se tratar de "situações em que cada curso possível de ação viola certo princípio moral que também é, por seu lado, obrigatório" (Blackburn, 1997e: 102). Desse 
modo, se considerarmos as situações que podemos qualificar de esquizofrênicas, representadas pelos autênticos dilemas morais, veremos que estes podem representar um sério desafio para quem deva tomar uma decisão difícil nesse tipo de situação, sobretudo para qualquer clínico consciencioso.

Em realidade, um dilema não tem propriamente uma solução decorrente de um raciocínio lógico cogente (por isso é um di-lema), e as soluções encontradas sempre serão parcialmente arbitrárias (indicadas por isso pela imagem da escolha de Sofia), visto que, quando se age no respeito de algum princípio moral importante (como um dever), acaba-se por infringir outro princípio moral igualmente importante (que pode ser outro dever). Assim, uma tomada de decisão em situação moralmente dilemática parece situar-se sempre no campo da tragédia, uma vez que implica escolher entre soluções acerca das quais não se sabe sempre muito bem dizer, de antemão, qual é a mais correta ou qual é a mais errada - como nos casos de ter que escolher quem deve viver e quem não, quem merece cuidado e quem merece menos ou nenhum em determinadas circunstâncias, como aquelas de escassez de meios ou de recursos.

Em outros termos, as ações abordadas pela bioética clínica são práticas que se inscrevem em um cenário caracterizado pela conflituosidade que, para ser legitimamente resolvida, deve ser aceita como constitutiva das próprias interrelações humanas e, por isso, demanda reflexão sobre o processo que leva do conflito à sua possível resolução, e também o conhecimento dos possíveis argumentos envolvidos, de seus conceitos e dos agenciamentos entre eles (que podem ser cogentes ou não). E isso graças à análise crítica dos conceitos utilizados e de seus significados e modos de se articularem entre si nas várias argumentações em campo.

Mas esse poderia ser um campo legítimo daquela que chamaríamos, com mais propriedade, de metabioética, entendida aqui como a análise da linguagem da bioética e das questões conceituais e argumentativas envolvidas na moralidade estudada também pela bioética clínica. Esta, como vimos, pode ser entendida como subconjunto da bioética como um todo, começando pela análise do próprio conceito problemático de vida, que analisamos em outro escrito (Schramm, 2009) e não será abordado especificamente aqui. 


\section{Metaética e metabioética}

A metabioética pode ser entendida como a parte metaética do saber bioético, ou seja, como o conjunto de ferramentas utilizadas pela(s) bioética(s) em sua(s) análise(s) dos conflitos no campo das ciências da vida e da saúde. Consideradas tanto em suas dimensões descritiva e normativa quanto em seus contextos reais específicos de conflituosidade, tais ferramentas conformam os próprios conceitos utilizados e os raciocínios elaborados graças a eles.

Em outros termos, a metabioética pode ser vista como uma forma de conhecimento que é uma parte da metaética, ${ }^{4}$ a qual é a parte da ética que analisa a linguagem moral (da mesma forma que a metalinguagem é a análise da linguagem). Ao passo que a ética pode ser entendida também - de acordo com uma sugestão de Ricardo Maliandi - como "tematização do ethos", isto é, como aquela parte da ética que "tem caráter reflexivo" e é, também, "parte constitutiva do ethos" ou parte "do objeto de tal reflexão" - o que nos levaria "ao paradoxo de que a ética, como tematização do ethos, resulta ser, ao mesmo tempo, tematização de si mesma" (Maliandi, 2004: 17).

Mas considerando essa relação entre ethos e tematização do ethos - que é, por isso, uma relação que poderíamos chamar de topológica -, pode-se considerar a metaética como "disciplina filosófica que tematiza e procura resolver ou, pelo menos, esclarecer os problemas morais" e, portanto, deve enfrentar "um conglomerado de problemas" que se referem "a algum tipo de relação conflituosa" (Maliandi, 2004: 11). Ou seja, é essa conflituosidade intrínseca às relações humanas (já destacada por Maquiavel) que constitui o referente ao qual se aplica tanto a ética (diretamente) quanto a metaética (indiretamente), o que implica admitir, por um lado, "a inevitabilidade [a priori] dos conflitos" e, por outro, "uma pluralidade de princípios" para poder dar conta deles e, ao mesmo tempo, se dar conta de que isso "exige maximizar a harmonia entre eles" (Maliandi, 2004: 12).

Assim, em suas interrogações, a metaética - entendida não mais em seu sentido estrito, mas ampliado - deverá responder a perguntas do tipo:

\footnotetext{
${ }^{4}$ Seria possível afirmar também o contrário, dizendo que a metaética está se tornando parte da metabioética, porque - como vimos - o paradigma linguístico pode ser visto como vinculado a um paradigma da vida, ou como um subconjunto deste. Aqui deixaremos, no entanto, a questão em aberto.
} 
1) O que significa dizer que algo é bom, correto ou justo?

2) Como conhecemos o que está certo ou errado?

3) Como as atitudes consideradas morais podem motivar uma ação?

E, ademais:

4) O que são os valores? Existem valores objetivos? Absolutos?

5) O que é uma norma ética, e como são criadas as normas?

Todas essas perguntas (a lista não é, evidentemente, exaustiva) fazem parte do âmbito de reflexão da ética e da bioética (que são a metaética e a metabioética), reflexão que visa a descrever as normas em vigor, mas também fundamentá-las e, eventualmente, questionar as fundamentações vigentes (como exige o pensamento dito crítico). Inclusive esclarecendo o sentido e o uso dos termos da linguagem moral vigente, para poder confrontá-la com eventuais alternativas em gestação no próprio ethos entendido também - de acordo com a sugestão de Maliandi (2004) - como uma tematização de si mesmo.

Por isso, pode-se dizer, em síntese, que metaética e metabioética, entendidas como tematizações da ética e da bioética - mas inseparáveis do próprio ethos -, implicarão necessariamente ferramentas analíticas e interpretativas como a explicitação dos conceitos, as investigações lógico-semânticas que lhes dizem respeito, sistematizações teóricas e análises das eventuais logomaquias em campo, para que se possa reconstruir, de forma pertinente e crítica, o ethos autorreflexivo ao qual se refere a bioética e, em particular, a metabioética. Mas implicarão também enfrentar a prática das inter-relações quando isso for julgado necessário (por exemplo, na abordagem de um conflito específico no set da prática clínica).

Assim sendo, e partindo do pressuposto de que existe um saber moral préfilosófico que qualquer ser racional dotado de vontade, e independentemente da tematização ética em pauta, possui, mas só pode ser expresso pela terminologia e pela metodologia filosóficas, Maliandi $(2004: 29,34)$ considera que a ética deveria ser entendida, em última análise, como "a reconstrução normativa crítica de um saber intuitivo, pré-teórico", reconstrução que, "ao mesmo tempo que explicita [este] saber pré-teórico (...) procura tornar compreensível 
o fato complexo da moralidade". Por isso, para o filósofo argentino haveria "no ethos uma tensão constante entre as incumbências do racional e do emocional, ou seja, uma dicotomia cabal entre logos e pathos" (Maliandi, 2004: 44). Em suma, haveria uma dialética entre razão e emoção, que a ética contemporânea não pode se eximir de enfrentar se quiser estar à altura da complexidade real dos conflitos vigentes nas inter-relações humanas, inclusive aquelas construídas na prática clínica, na qual é sempre possível a falta de consenso entre os atores envolvidos.

\section{A pertinência do método da análise conceitual da metabioética e o caso dos pseudoconceitos}

Se uma função certamente importante dos conceitos é se referir ao real e tentar entendê-lo, e da análise conceitual é esclarecer a maneira como usamos os conceitos para tentar dar conta de tal referência e de tal entendimento, diante de conceitos mal definidos, ou pseudoconceitos, ficamos muitas vezes sem saber o que se deveria pensar (ou representar ou construir) por meio deles. Ou seja, ficamos perplexos diante da "dimensão real, ou não, daquilo que pensamos" (Benoist, 2011b: 9).

Diante desse mal-estar na presença de conceitos inconsistentes ou mal definidos, e que não sabemos bem dizer para que podem realmente servir, a análise conceitual - que pode ser entendida também como "o verdadeiro nome da filosofia" (Benoist, 2011b: 10) - parece mostrar que os conceitos dependem também - como já vimos - de sua referência ao real, pois do ponto de vista de uma possível "filosofia realista" capaz de "compreender o que (...) fazemos com aquilo que temos" (Benoist, 2011a: 10), é no real que se situa, em última instância, nossa existência e aquela dos outros com os quais interagimos.

Mas essa referência ao real, aparentemente evidente por fazer parte de nossa experiência, é de fato também problemática, senão paradoxal, teoricamente, como indica a polissemia do próprio termo real. De fato, real pode significar inter alia "verdadeiro", "concreto", "que existe realmente", "que não é falso, ilusório ou artificial; genuíno" (Houaiss \& Vilar, 2001: 2.391). Ademais, o termo pode indicar algo que "age efetivamente" e que se opõe ao "relativo", ao "ideal", ao "possível"; referindo-se, portanto, "às coisas como são, e não como poderiam ser ou deveriam ser", mas também ao que se opõe ao "relativo", 
ao "fenomênico" e ao "aparente". Por fim, não se deve esquecer que real é muitas vezes concebido como sinônimo perfeito de realidade, com o sentido de "caráter daquilo que é real" ou de "o que é real", caso em que se pode falar em "anfibologia das palavras real e realidade", a qual pode ser considerada causa de paralogismos (Lalande, 1972a: 894).

Um caso interessante dessa anfibologia é a concepção e o uso do termo real feitos pelo psicanalista Jacques Lacan ao longo de sua obra. Para Lacan, por um lado haveria uma congruência entre real e simbólico, pois "tudo que é real é racional", e, por outro, o real parece se opor ao simbólico, ficando além deste (ao qual não se ajustaria), pois "o real [é] o âmbito daquilo que subsiste fora da simbolização (...) ele está lá, idêntico a sua existência [e sendo] rumor onde tudo pode ser entendido" (Lacan, 1966: 226, 338). Entretanto, para a concepção topológica de Lacan, existe também uma ligação entre real e ética. Por exemplo, no Seminário XI ele afirma que "o estatuto do inconsciente é ético" e "frágil no plano ôntico", ou - mais diretamente - "o estatuto do inconsciente é ético, não ôntico", porque o inconsciente "se mostra" (Lacan, 1973: 31-35).

Segundo a psicanalista Alenka Zupančič, para Lacan tratava-se de "vincular a ética da psicanálise à ética do Real (...) no sentido de que o real não se refere ao ser, mas a algo que, embora não exista na maneira do ser, tem consequências negativas para o ser" e, sobretudo - o que mais nos interessa aqui -, "o Real não é o 'além do discurso (ou da linguagem)'”, mas o que é capturado no discurso e transforma sua "estrutura e lógica", visto que "o Real é desde sempre aqui, atrás de nós, em nós, e que articula aquela estrutura com a qual tentamos aproximá-lo" (Zupančič, 2012: 15-16).

Diante dessas dificuldades, parece mais promissor considerar que, no caso da bioética clínica, a análise conceitual tenha não tanto o papel de estabelecer uma relação "correta" entre fatos reais e sua simbolização (que é de fato um problema epistemológico, além de psicológico), mas, sobretudo, o valor de método, consistente na "elucidação do sentido das questões que dizem respeito à 'realidade' deste ou daquele gênero de coisas ou seres" (Benoist, 2011a: 9). E isso tendo em conta que todo conceito é sempre finito, limitado a uma porção do real, o que impede a determinado conceito dar conta das outras porções do real, como bem mostram a história das ciências e a sucessão de seus paradigmas legítimos que se estabeleceram e declinaram ao longo do tempo. 
Há, portanto, conceitos que são pertinentes e outros que não o são quando nos referimos a determinada realidade conflituosa, como pode ser aquela abordada pela bioética clínica. Ou, dito diversamente, todo conceito é sempre finito, isto é, limitado a uma porção de realidade, e sua capacidade de dar conta de determinada porção de realidade parece ser exatamente o que o impede de dar conta das outras porções de realidade. Pois todo conceito depende do ponto de vista aplicado a uma porção de realidade, e não existe um ponto de vista concreto que contenha todos os pontos de vista possíveis sobre o real. Em suma, porque existem conceitos que são pertinentes e outros que não o são quando nos referimos a determinada realidade, como pode ser aquela abordada pela bioética clínica. Ademais, há partes da realidade para as quais não dispomos de conceitos e que indicamos justamente pelo denso termo real (no segundo sentido lacaniano aqui indicado).

Em síntese, a bioética clínica (mas também a bioética em geral) parece ter que lidar com problemas conflituosos concretos, argumentos e justificativas que sustentem suas decisões, elaborações construídas graças a conceitos e encadeamentos de conceitos e de argumentos, que podem ser analisados pela metabioética. Esta, longe de ser desnecessária (como supostamente ter-se-ia tornado a metaética depois do aparecimento do paradigma das éticas aplicadas), deve ser vista como uma ferramenta indispensável da própria ética prática e da bioética.

De acordo com a teoria dos signos - ou semiologia - de Ferdinand de Saussure ([1916] 1974), os conceitos conformam os significados dos signos e estes se referem a outros signos, dos quais devem se diferenciar para que haja sentido inteligível num discurso. Esta é a razão pela qual uma metabioética atenta deverá sempre ter em devida conta também tais características semióticas dos problemas morais, que se referem à análise formal dos argumentos morais utilizados pelos envolvidos, detectando suas estruturas semânticas, narrativas e temáticas que os caracterizam, para "tentar dar conta das articulações do discurso concebido como um todo de significação" (Mucchielli, 2011a: 243).

\section{Para Não Concluir}

Como tentamos mostrar ao longo deste ensaio, a problematização metabioética e a ferramenta conhecida como análise conceitual - concebida como 
ferramenta tanto da tradicional metaética como da metabioética - podem ser vistas como meios importantes para conhecer os juízos que comandam uma ação moral - graças à identificação dos conceitos envolvidos, à análise de seu encadeamento lógico nos argumentos morais produzidos para tentar justificar um determinado ato, e ao tipo de relação estabelecido com valores e princípios que orientam tal ação e permitem dizer se ela é moralmente correta ou não.

Em particular, as ferramentas da metabioética podem ser importantes para a própria bioética clínica, não somente para que os seus agentes morais possam utilizar corretamente os conceitos e raciocinar de maneira adequada (ou cogente), isto é, em substância, para se comunicarem entre si; mas também porque a escolha da cogência e de um método adequado, considerados necessários para analisar criticamente os conflitos morais que surgem na prática clínica, parece indispensável para um agir moral correto. Caso contrário, não saberíamos do que estamos de fato falando e, portanto, o que fazer. Ademais, isso é necessário quando se pretende articular o simbólico e o real de forma pertinente e significativa - isto é, que faça sentido para os envolvidos em um conflito de tipo moral -, permitindo enfrentar o problema de saber dizer, por exemplo, se uma afirmação de tipo moral é verdadeira ou falsa, pertinente ou não, justificada ou não. Ou seja, correta ou incorreta em uma situação concreta.

Portanto, existe uma preocupação teórica que não pode ser afastada (ou recalcada) facilmente, pois, de qualquer maneira, temos um vínculo "essencial com o real" tanto "nos pensamentos falsos" (e seus "conceitos vazios") quanto nos "pensamentos verdadeiros" (e seus "conceitos "plenos"), e esse "vínculo" pode ser visto como "um dado fundamental daquilo que chamamos 'pensamento'", pois "um pensamento só pode ser incorreto na medida em que ele está conectado com o real" (Benoist, 2011b: 73). Dito com outros termos, só parece existir conhecimento de um problema se o pensamento que o analisa for correto, e isso pode ser visto como condição necessária para que se possa dar uma resposta adequada a tal problema. Ou seja, existe um "vínculo constitutivo dos conceitos com a realidade, tanto no sucesso quanto no fracasso em sua aplicação" (Benoist, 2011b: 74). E é essa a ideia principal de uma filosofia realista para nossa problemática metaética ampliada, pois o principal objetivo de sua ferramenta, constituída pela análise conceitual, parece ser aquele de tentar "atingir a facticidade mesma dos conceitos (...) 
questionados em seu ser fundamentalmente mundano" e "fazer aparecer [as] divisões humanas primordiais das coisas que constituem muitas vezes a base de nossos conceitos", tentando assim "pôr em evidência suas consequências, desejáveis ou indesejáveis" (Benoist, 2011b: 202-203).

Finalizando, a tentativa de considerar a dimensão pragmática dos conceitos utilizados em bioética pode ser vista como uma característica daquela que podemos chamar a realidade do pensamento, a qual implica que se considere sua facticidade e suas implicações para a qualidade de vida de indivíduos e populações humanas. Sem esquecer o fato de que existem conceitos que podem se revelar conceitos verdadeiros ou pseudoconceitos, quando aplicados a situações concretas. Assim, uma condição necessária para que "nossos conceitos possam continuar sendo chamados de 'conceitos'" é que eles "conservem, em sua zona de pertinência respectiva, um poder discriminante" (Benoist, 2011b:173), para que não sejam vistos como conceitos vazios ou, simplesmente, confusos. Caso contrário, dificilmente serviriam como ferramentas pertinentes e legítimas da bioética clínica. Enfim, é somente submetendo-se um conceito "à prova de situações inéditas que tais potencialidades aparecerão ou não, e que sua zona de pertinência se configurará e se desvelará" (Benoist, 2011b: 180). 


\section{A Bioética e a Moralidade da Genômica}

Neste ensaio abordaremos a moralidade da prática humana no campo da genômica, considerando esta disciplina como um dos principais âmbitos das atividades da biotecnociência e entendendo a biotecnociência como "conjunto de ferramentas teóricas, técnicas, industriais e institucionais que visam a entender e transformar seres e processos vivos, de acordo com necessidades e desejos de saúde", tendo como principal objetivo o "bem-estar de indivíduos e populações humanas" (Schramm, 2005: 21).

O termo moralidade indica - de acordo com uma definição de dicionário - a qualidade ou característica do que é moral, ou - dito de maneira menos genérica - a qualidade da ação humana avaliada de acordo com um juízo de valor que em princípio permite dizer se está correta ou não. Mas o termo é entendido e utilizado de várias outras maneiras pertinentes. Pode, por exemplo, ter relação com aquilo que uma pessoa, um grupo ou uma sociedade deseja, professa ou faz; ou seja, referir-se às "práticas e opiniões efetivas de uma sociedade [ou] que deveriam existir", considerando deveres "cuja aplicação é independente de qualquer ato legislativo" (distinguindo a moralidade da legalidade), ou referir-se à oposição entre moralidade (Moralität) e eticidade (Sittlichkeit). Tal oposição foi introduzida por Hegel para indicar "o que diz respeito ao indivíduo autônomo" (a moralidade) e apresenta uma "incompatibilidade potencial 
com valores sociais comuns já estabelecidos e com os costumes e instituições que dão corpo e sustentam esses valores" (a eticidade) (Mautner, 2010b: 509-510, destaques do original).

O termo pode ser referido também a uma característica ou a um "valor (positivo ou negativo) do ponto de vista do bem e do mal", aplicável "tanto às pessoas como aos juízos e aos atos" (Lalande, 1972b: 656). Nesse sentido, moralidade pode se referir tanto ao agente como a seus atos, o que permite falar em moralidade do agente e moralidade do ato, ou seja, considerando como pertinente uma característica ou qualidade de quem age (como quando se diz de alguém que é boa ou má pessoa), movido, por exemplo, por um dever; ou - de acordo com as consequências da prática do agente moral - devido a uma característica ou qualidade daquilo que é produzido por quem age, e que pode ser visto como independente das motivações do agente.

No âmbito da filosofia moral, um dos primeiros sentidos específicos do termo moralidade é aquele proposto por Kant na Fundamentação da Metafísica dos Costumes (1785) e na Crítica da Razão Prática (1788), em que o filósofo distinguia moralidade e legalidade. Articulando-as sem separálas, Kant considerava serem ambas expressão de nossa relação com a lei, entendendo legalidade como mera conformidade da ação às normas morais vigentes e moralidade como a qualidade da ação quando o agente moral é movido pela "intenção pura" do "respeito pelo dever", pois "a legalidade da ação está englobada em sua moralidade, mas as exigências da moralidade ultrapassam aquelas da legalidade" (Pariente-Butterlin, 2000: 55); em ambos os casos sem ter em conta as consequências da ação nem as contingências socioculturais em que esta se efetiva.

Um segundo sentido específico se refere às consequências de um ato, seja este voluntário ou involuntário, previsto ou não. Esse é o sentido adotado pelo utilitarismo a partir de J. Bentham, que formulou, em sua Introdução aos Princípios da Moral e da Legislação ([1789] 2007), o princípio de utilidade, segundo o qual um ato é moral se promover maior quantidade de felicidade, ou seja, de prazer e ausência de dor.

Tendo em conta os conteúdos da deontologia kantiana e aqueles do consequencialismo dos utilitaristas, aqui o termo moralidade será entendido no 
sentido inclusivo de característica do ato humano, analisada e julgada de acordo com parâmetros valorativos que permitam dizer se este é correto ou incorreto, justo ou injusto, em determinada situação e tendo em conta não somente as boas intenções, mas também suas consequências. Por sua vez, a ética será entendida como o estudo da moralidade dos atos humanos, considerados corretos ou incorretos de acordo com determinadas características, como aquela - destacada pela deontologia - do agente moral capaz de cumprir seus deveres (como aqueles contidos em sua deontologia profissional) ou aquela destacada pela abordagem consequencialista - de produzir bem-estar ou evitar sofrimento não necessário.

Neste ensaio, a pergunta que norteia nossa investigação pode ser formulada da seguinte maneira: o que do trabalho dos profissionais da genômica poderia ter de moralmente desejável ou questionável, levando-se em conta os possíveis efeitos positivos e/ou negativos sobre a qualidade de vida dos humanos e dos seres vivos em geral, uma vez que as ferramentas da genômica são aplicáveis a qualquer ser e sistema vivo?

Trata-se de pergunta aparentemente retórica, pois parece sugerir que estaria em questão a liberdade humana de conhecer e pesquisar. Mas isso seria contrário a toda a história da produção cultural humana amplamente entendida a partir da Idade Moderna, quando surge a ciência experimental, em princípio inseparável da criatividade e da autonomia dos pesquisadores, pois "a liberdade permite fazer coisas que os objetivos específicos programados ou planejados não permitem". Embora, atualmente, o novo modo de "produção, apropriação e regulação dos saberes ligado ao neoliberalismo [tenha] modificado em profundidade a paisagem da pesquisa", criando "mercados do conhecimento" e implicando que "uma concepção estreita da pesquisa científica e do trabalho dos pesquisadores tenda a ser erigida como modelo dominante" (Catellin, 2014: 214).

Ademais, a pergunta pode parecer inapropriada se considerarmos a reduzida extensão do conceito de moralidade, aplicado àquilo que o senso comum considera como moralmente correto, ao invés de referir-se ao universo constituído pelos prós e contras, como exige o significado técnico do termo, que se refere a um objeto que deve ser abordado por "uma atividade racional e uma pesquisa crítica" (Mori, 1997: 12). 
Entretanto, apesar das possíveis dificuldades que acabamos de apontar, a pergunta é pertinente e justificada se a referirmos ao duplo sentido - cognitivo e moral - do verbo poder. Duplo sentido que perpassa a história da cultura desde a época mitopoiética grega, começando pelo pensamento religioso e a filosofia antiga até chegar aos nossos dias, quando ela constitui uma interrogação fundamental tanto da epistemologia e da metodologia como da própria ética e da política.

Portanto, falar em moralidade da genômica faz sentido se considerarmos a genômica como uma prática que implica "o estudo da estrutura e funcionamento do material genético total (genoma) de um organismo" (Salzano, 2004: xiii) e se aplica concretamente na prática biotecnocientífica, a qual envolve não só conhecimentos (conceitos, teorias) e técnicas, mas também dispositivos $^{5}$ que implicam relações de poder entre pesquisadores, sujeitos pesquisados, financiadores, indústria e mercado. E isso porque tais relações inevitavelmente resultam em conflitos de interesses, que constituem um dos tópicos mais candentes da problemática ética em pesquisa dos últimos anos, devido especialmente à sua relação com a cultura dos direitos humanos e, em particular, com os direitos dos sujeitos (ou pessoas), objetos de pesquisa, diante do dispositivo biotecnocientífico.

A expressão conflito de interesses, registrada nos dicionários da língua inglesa desde 1971, vem sendo utilizada hoje na ética dos negócios, na ética das profissões e, de forma crescente, também na ética pública, podendo-se dizer que pertence atualmente à linguagem de qualquer código deontológico e de qualquer cálculo de tipo utilitarista. De fato, seu significado pode ser referido ao "conflito entre um dever público e um interesse privado", o que pode "influenciar o cumprimento dos deveres ligados ao [primeiro]" e introduz no debate o problema de uma "previsível falta de confiabilidade do juízo de quem se encontra em tal situação de conflito" (Cremaschi, 2006: 2.182). Entretanto, conflito de interesses deve ser distinguido de "conflito entre deveres", que implica - como o nome indica - uma incompatibilidade entre deveres; isto é, em princípio uma impossibilidade (ou incapacidade) de cumprir um dos

\footnotetext{
${ }^{5}$ De acordo com Giorgio Agamben (2006: 22), um dispositivo é um instrumento de poder que tem “a capacidade de capturar, orientar, determinar, interceptar, modelar, controlar e assegurar os gestos, as condutas, as opiniões e os discursos dos seres vivos".
} 
deveres concorrentes (e que pode se caracterizar em determinadas situações como um dilema moral), mas sem que isso afete necessária e substancialmente o juízo, ao passo que o conflito de interesses implica sempre "influenciar a normal capacidade de juízo" (Cremaschi, 2006: 2.182).

No campo da saúde - em que pretendemos situar este ensaio -, o termo conflito de interesses adquire, de acordo com o bioeticista Sergio Zorrilla (2007: 65),

pelo menos desde a Declaração de Helsinque, um estatuto particular, por ser entendido como processo e fonte de riscos para os direitos humanos dos sujeitos da experimentação [e] como perturbação e desestabilização constante do bom equilíbrio entre dois imperativos: por um lado, a prioridade absoluta de preservar a saúde e o bem-estar do ser humano para além dos interesses da ciência e da sociedade, e, por outro lado, a necessidade permanente de recorrer à experimentação humana, à inovação terapêutica e tecnológica, com a finalidade de também preservar a saúde do ser humano.

Para o autor, essa dupla obrigação moral ante um mesmo objetivo se daria no âmbito de uma série de mudanças sociológicas ocorridas no campo da pesquisa e das relações que esta mantém com a economia e a biotecnociência "no contexto de uma produção massiva" de pesquisadores e médicos e de uma "divisão crescente entre dirigentes e dirigidos". Em tal contexto, caberia reconhecer, nas "duras exigências do mercado de trabalho", "uma fragilidade da consciência do pesquisador" para resolver adequadamente os conflitos de interesses, pois "para muitos, queiramos ou não, o primeiro interesse [consiste] em ter acesso ao trabalho e à própria reprodução da vida" (Zorrilla, 2007: 70-71).

Assim, poder-se-ia dizer que "durante as últimas décadas, o ethos dominante no mundo da ciência tem mudado de forma insidiosa", porque o que era "um empreendimento coletivo [e] compartido é atualmente limitado, com frequência, pelas exigências da competição comercial", com muitos pesquisadores que "só compartem suas descobertas com o resto da comunidade sob a proteção da lei das patentes ou do segredo comercial" e outros "se agarrando aos velhos ideais da ciência" (Sulston \& Ferry, 2003: 2-3).

Apresentadas essas considerações introdutórias à problemática da moralidade da genômica, podemos entrar no mérito de sua avaliação, feita pela ética e pela bioética. 


\section{A Avaliação da Moralidade da Genômica entre Tecnofilia e Tecnofobia}

Historicamente, a avaliação da moralidade das práticas biotecnocientíficas, constituídas pelo uso das biotecnologias e referentes ao saber da genômica, tem recebido uma série de respostas que podem ser situadas entre dois polos opostos:

1) o polo representado pelos "tecnofílicos" ou "entusiastas panegíricos da técnica", que, amparados no princípio de beneficência ou de realização, "prescrevem aceitar e aplaudir as conquistas da técnica" e só admitem "as primícias genéticas que podem favorecer a saúde humana";

2) aquele dos "tecnofóbicos", que partem da premissa de que toda técnica é perigosa e de que "seu perigo aumenta proporcionalmente ao seu grau de complexidade e sofisticação" e, amparados pelo princípio da não maleficência ou da conservação (e, em alguns casos, da precaução), exigem "pôr barreiras onde essas primícias acarretam verdadeiros riscos para a saúde" ou "relações de domínio [que perturbam o] equilíbrio etológico" (Maliandi \& Thüer, 2008: 233-241).

Para Maliandi e Thüer, diante de tais atitudes polarizadas, que impedem o diálogo, seria mais razoável adotar uma atitude de convergência, a qual "pode admitir a técnica, e, portanto, a biotecnologia, como imprescindível e, inclusive, admirável, desde que não se percam de vista, ao mesmo tempo, os inúmeros perigos que ela implica", pois uma "aprovação com precaução será sempre uma atitude mais razoável que [uma] aprovação sem precaução ou [uma] precaução sem aprovação" (Maliandi \& Thüer, 2008: 242).

\section{Os dois tipos de resposta e seus argumentos}

Os dois tipos de resposta - as dos tecnofílicos e as dos tecnofóbicos - à pergunta inicial sobre a moralidade da prática da genômica se baseiam nos argumentos que apresentaremos a seguir:

1) Sim, estamos autorizados a saber tudo aquilo que somos capazes de saber devido à curiosidade legítima que nos caracteriza e às ferramentas operacionais e cognitivas que possuímos - estruturadas e sistematizadas pelas ciências e pelas técnicas ao longo de suas histórias respectivas, e organizadas pelos seus dispositivos de produção, divulgação e controle. 
De acordo com esse argumento, saber e saber-fazer seriam algo em princípio positivo e legítimo, visto que servem para entender os fenômenos e a nós mesmos, tentando transformá-los - e nos transformar - quando isso for considerado necessário (ou talvez simplesmente desejável), e visando, em última instância, a resolver problemas para melhorar a qualidade de vida das pessoas e das populações humanas.

2) Não estamos autorizados a saber tudo o que em princípio temos competência cognitiva para saber, e haveria, portanto, um conhecimento proibido, visto que "nossas descobertas dos segredos da natureza, cada vez mais audazes, podem ter chegado a um ponto em que o conhecimento nos traz mais problemas do que soluções, [pois] aprendemos a fazer certas coisas muito antes de saber o que estamos fazendo e de maneiras que ninguém pode explicar de forma adequada" (Shattuck, 1998: 15-16). Por isso, só deveríamos saber e saber-fazer o que não é contrário a tal interdição ou não prejudique a nós e aos outros seres que compõem, juntos, o nosso mundo, por cuja gestão somos coletiva e pessoalmente responsáveis, inclusive no sentido de proteger os melhores interesses das gerações futuras e a sustentabilidade do próprio planeta - que deve ser preservado (ou protegido) contra eventuais danos evitáveis ocasionados por esses tipos de saber em suas aplicações.

Numa primeira avaliação crítica, podemos dizer que a primeira resposta é aparentemente menos problemática do ponto de vista moral, pois parece intuitivamente aceitável argumentar que o saber, ao aumentar a competência do Homo sapiens (que é também Homo faber) para compreender o mundo e a si mesmo, seja algo desejável e em princípio legítimo, inclusive para aplicá-lo concretamente, tendo em vista a preservação ou o aprimoramento da qualidade de vida humana (e, eventualmente de outros seres vivos e dos ambientes). Mas essa resposta pode se tornar problemática se considerarmos, por exemplo, que a pesquisa científica "[confia] numa certeza não explicitada de que a liberdade total no intercâmbio dos produtos simbólicos da mente não afeta de maneira necessariamente adversa o domínio da vida diária e é bem capaz de aperfeiçoá-lo" (Shattuck, 1998: 19-20), visto que não teríamos em devida conta os efeitos que podem ser positivos e/ou negativos - da cultura científica sobre nossas vidas. Ou se pensarmos na modificada condição antropológica e sociológica 
atual, em que é praticamente impossível separar a competência do Homo sapiens daquela do Homo faber, isto é, se relacionarmos o saber teórico (ou logoteórico) e o saber-fazer técnico (ou tecnopoiético), que se tornaram de fato inseparáveis desde que a ciência se transformou em tecnociência e as ciências biológicas em biotecnociência e biotecnologias. Ou seja, se pensarmos ao mesmo tempo no processo de conhecer o real e naquele de transformá-lo, assim como nas inter-relações desses dois processos, e compreendermos o que é o homem e tentarmos transformá-lo em suas características - adquiridas durante o longo processo biológico chamado evolução - justificando tal intervenção com vantagens comparativas (reais ou supostas) ou com valores morais que parecem convergir para algum tipo de beneficência ou um bem, mas que, em realidade, são dificilmente convergentes e nem sempre aceitos por todos os atores sociais racionais envolvidos (ou que possam vir a se envolver no futuro).

Entretanto, na primeira resposta raramente se faz a distinção (clássica) entre o aspecto logoteórico da elaboração do conhecimento e o aspecto tecnopoiético de sua produção, sendo que o aspecto tecnopoiético quase sempre está ainda subsumido no logoteórico, de acordo com uma concepção tradicional de ciência, separada de suas aplicações tecnocientíficas e biotecnocientíficas. Embora, no novo contexto globalizado em que se constrói o saber-fazer tecnocientífico e biotecnocientífico, os "temas de pesquisa [sejam] definidos de maneira demasiado estreita por interesses industriais ou por grupos de pressão, com objetivos de curto prazo tendo em vista resultados rapidamente aproveitáveis" (Catellin, 2014: 207). Assim, saber como é o mundo e ser capaz de transformá-lo parecem tornar-se, ambos, moralmente corretos, pelo menos se considerarmos que tais operações visam, em última instância, a melhorar ou, pelo menos, a manter a qualidade de vida dos humanos, presentes e futuros, em um mundo transformado, inclusive devido a causas de origem antrópica. Isso estaria ocorrendo, sobretudo, graças aos avanços da biomedicina - e da saúde pública - nos âmbitos da prevenção, da previsão e do tratamento de moléstias e doenças antes não tratáveis. Em suma, nesse contexto, conhecer e saber-fazer seriam moralmente preferíveis à ignorância e à "incompetência".

Mas a uma inteligência (ou sensibilidade) atenta aos avanços da biotecnociência e às várias percepções e simbolizações a seu respeito, e sem 
preconceitos - ou posições apriorísticas - sobre tais avanços, frases como "não se deve querer saber tudo" ou "nem tudo aquilo que é tecnicamente possível é moralmente legítimo" - dois dos principais chavões que circulam no imaginário social - podem parecer pelo menos estranhas. E isso, basicamente, por dois motivos. Primeiro porque, em realidade, não sabemos tudo nem fazemos tudo o que sabemos - haja vista a contínua troca de paradigmas científicos ao longo da história das ciências e os avanços técnicos, científicos e biotecnocientíficos que, ao longo do tempo, tornaram nossas práticas mais efetivas, muitas vezes abandonando técnicas e procedimentos vigentes. Segundo, porque parece cada vez mais sensato pensar que a própria sobrevivência da espécie humana dependa não somente da mudança de comportamentos e de padrões de consumo - que devem ser, em última instância, sustentáveis -, mas também dos meios propiciados pela ciência e pela técnica. Ou, mais precisamente, de uma sábia aliança entre as capacidades do Homo faber e aquelas do Homo sapiens, em princípio capazes de controlar os eventuais deslizes do Homo sapiens demens (Morin, 1973).

Não sabemos tudo porque, de acordo com o estudo das condições do conhecimento - abordadas pela epistemologia e pela metodologia -, só se pode saber algo a partir de algum ponto de vista. $\mathrm{Ou}$ - se levarmos em conta os aspectos metodológicos do processo concreto de conhecer - de um conjunto de pontos de vista diferentes e pertinentes, que podem relacionar-se entre si de diferentes maneiras. Por exemplo, de maneira meramente pluridisciplinar na análise de um fenômeno, em que os pontos de vista não têm uma relação direta entre si; ou de maneira um pouco mais ambiciosa, chamada interdisciplinar, em que diferentes pontos de vista se inter-relacionam; ou, então, numa autêntica relação transdisciplinar, entendendo a transdisciplinaridade como "etapa (...) em que não bastaria atingir as interações ou reciprocidades entre pesquisas especializadas [como na interdisciplinaridade], mas que situaria tais laços no interior de um sistema total sem fronteiras estáveis entre disciplinas" (Piaget, 1972: 144). Mas, de qualquer maneira, nunca de todos os pontos de vista possíveis, pois isso exigiria ou um ser-que-sabe-tudo (metaforizado pela imagem de um deus onisciente) ou um dispositivo capaz de saber tudo (uma espécie de máquina pensante com poderes cognitivos infinitos como aquelas representadas pela ficção científica). Em outros termos, devido a tais limites da 
razão humana - já destacada pela epistemologia kantiana (Kant, 1989) - e da linguagem humana - destacada por Wittgenstein (2005) -, não podemos saber tudo porque não existe um ponto de vista - ou não conseguimos imaginar tal existência de maneira cogente - que contenha todos os pontos de vista possíveis, capazes de dar conta de tudo (a não ser, talvez, matematicamente, como conjunto transfinito contendo todos os infinitos, algo de fato dificilmente representável e realizável).

No entanto, o lema que reza que nem tudo aquilo que sabemos fazer deve ser feito é intuitivamente válido do ponto de vista moral, pois, por exemplo, sabemos matar, embora isso não implique necessariamente a passagem ao ato (pelo menos não sem uma boa razão). Mas quando o lema está associado ao assim chamado imperativo tecnológico - pressuposto segundo o qual o dispositivo representado pela biotecnociência seria algo cego, irresistível e que se imporia ao Homo sapiens/demens independentemente da sua aceitabilidade do ponto de vista moral, assim como de seus riscos presentes e futuros -, podem surgir questionamentos sobre sua pertinência e legitimidade. De fato, como acabamos de lembrar, só se sabe algo de acordo com algum ponto de vista e com alguma intenção cognoscente - o que resulta sempre em um conhecimento limitado e focado -, e só se pode saber-fazer algo a partir do interesse e/ou do desejo de realizar concretamente algo tendo algum saber pressuposto, e realizando esse saber concretamente.

Em outros termos, a primeira resposta deixa em aberto as implicações da questão da ignorância (e do direito ao não saber), que, por falta de uma abordagem crítica, só pode ser indicada por imagens negativas como aquelas do mítico vaso de Pandora, cheio de perigos; ou aquela do destino do Prometeu da mitologia antiga, punido pelos deuses por ter dado o fogo e seus poderes de transformação ao Homo faber; ou, ainda, pela imagem do Fausto de Goethe, que vende a alma ao diabo em troca do saber. São imagens de fato reutilizadas atualmente sobretudo pela ficção científica.

A segunda resposta é mais próxima àquela parte do imaginário contemporâneo preocupada não só com os benefícios - reais ou potenciais - do saber científico e do saber-fazer tecnocientífico, mas também com os riscos implicados pela utilização de seus produtos e procedimentos, e com os eventuais 
efeitos adversos (e perversos) de nossas ações no futuro, ações praticamente impensáveis no presente, visto que se baseiam nos saberes e nas modalidades de saber-fazer - sempre limitados - que temos atualmente e em seus dispositivos de controle sempre imperfeitos.

Mas essa problemática nos obriga a enfrentar duas outras questões, interligadas:

1) a questão objetiva das relações entre ciência e técnica, e de suas transformações em tecnociência e biotecnociência, que implicam cada vez mais efeitos previstos e efeitos imprevistos sobre o real e sobre a qualidade da vida humana presente e futura, os quais dependem de nossas ações responsáveis, ou não, sobre o mundo e sobre nós mesmos;

2) a questão subjetiva da relação entre a competência técnica do Homo faber e a competência racional do Homo sapiens, indicada, de forma problemática, pela expressão imperativo tecnológico, identificada a uma espécie de destino e que de fato subsume a competência do Homo sapiens àquela do Homo faber, suscitando, portanto, questões eticamente relevantes, como aquela da liberdade e da responsabilidade - presente e futura - dos cientistas e dos técnicos que trabalham no âmbito da biotecnociência, capaz de transformar o mundo e o próprio homem.

Entretanto, a primeira resposta - a dos tecnofílicos - tem uma variante: aquela que considera a biotecnociência como uma resposta correta à condição humana de neotenia.

\section{O argumento da neotenia para justificar o uso da biotecnociência}

O conceito de neotenia foi desenvolvido pela biologia do desenvolvimento para indicar um desenvolvimento incompleto em algumas espécies animais, indicando "[a] persistência no desenvolvimento de uma espécie de caracteres próprios de estádios larvares ou pré-adultos" (Dicionário Rex) ${ }^{6}$ ou "pedomorfose produzida pelo retardamento do desenvolvimento somático, de maneira que a maturidade sexual é atingida em um organismo que retém

\footnotetext{
${ }^{6}$ Disponível em: <http://senhordaspalavras.com.br/significado/neotenia>. Acesso em: 6 maio 2013.
} 
características juvenis", entendendo-se pedomorfose como "presença de caracteres primitivamente juvenis, larvais ou embrionárias em um organismo adulto" (Houaiss \& Vilar, 2001: 2.164).

A ideia central desse conceito - o desenvolvimento incompleto - servirá aqui para indicar a condição humana de incompletude e as tentativas do Homo sapiens de responder a tal limitação (ou pelo menos de contorná-la) graças aos avanços da biotecnociência, e que a bioética analisa a partir de sua caixa de ferramentas, a qual permite a articulação entre três questões que, em nosso entender, embora distintas, não devem ser separadas:

1) a questão da condição humana caracterizada, ao nascer, pela imaturidade biológica e pelo desamparo psicológico, que implica um ser vivo pouco especializado e em princípio adaptável a qualquer nicho ecológico;

2) a questão da aventura humana, caracterizada pela construção e pelo uso da tecnociência e da biotecnociência, e que em princípio permite auxiliar a primeira natureza do Homo sapiens - que é de tipo biológico - com uma segunda natureza - que é técnico-cultural -, podendo-se dizer que tais artefatos realizam uma espécie de síntese entre as competências tanto do Homo faber como do Homo sapiens; e

3) a questão dos meios supostamente capazes de orientar, controlar e/ou limitar o agir humano, como as ferramentas da bioética, as quais são de tipo descritivo-compreensivo e de tipo prático-normativo, e se ocupam das práticas humanas que podem ter consequências irreversíveis sobre o mundo, entendido como entidade constituída por sistemas vivos integrados em seus ambientes ou contextos.

Em realidade, o humano é neotênico e desamparado, imaturo e desprotegido com relação ao ambiente no qual terá de sobreviver. Essa característica é comum a praticamente todos os mamíferos e mostra a importância dos cuidados parentais com a prole nesse estágio evolutivo da matéria viva, proteção sem a qual o pequeno Homo sapiens em princípio não sobreviveria. Por isso, a técnica e a cultura em geral constituem duas vantagens comparativas que nossa espécie construiu ao longo de sua história para sobreviver, tomar conta do mundo e transformá-lo conforme seus desejos e projetos, inscritos em sua práxis. 
Em particular, graças à revolução cultural representada pela emergência e afirmação do paradigma biotecnocientífico em meados do século $\mathrm{XX}, \mathrm{o}$ humano tornou-se em princípio competente para reprogramar, a princípio ad libitum, o mundo natural, inclusive para reprogramar-se a si mesmo conforme seus desejos, projetos e necessidades. É isso que poderíamos chamar de biotecnologização do mundo, a qual constitui um dos campos problemáticos abordado pela bioética, que, nesse caso, pode ser vista como instância normativa das práticas no âmbito da biotecnociência, tendo em vista a proteção diante da vulnerabilidade ou da efetiva vulneração dos sistemas vivos e de seus ambientes, inclusive a vulnerabilidade/vulneração da espécie humana, ameaçada pelos próprios seres humanos e seus projetos e produtos. Por isso, poder-se-ia dizer que há um nexo lógico entre a vulnerabilidade/vulneração da condição humana, a criação dos meios sociais, técnicos e culturais do humano para contornar as limitações decorrentes dessa condição existencial e as formas de controle contra os abusos dos meios humanos aplicados ao mundo da vida.

De fato, a qualidade de vida dos humanos existentes e das gerações futuras assim como o bem-estar dos animais sencientes e a qualidade do meio ambiente - parecem depender cada vez mais daquilo a que podemos chamar de revolução biotecnocientífica, cujos avanços conceituais e cujas principais aplicações práticas se dão nos âmbitos da genômica e, em particular, nas realizações das biotecnologias e da engenharia genética (e mais recentemente da nanotecnologia). Em outros termos, os produtos da biotecnociência - ou biotecnologias - deixaram de ser meros produtos da ficção científica para se tornar parte do mundo real, objeto de esperanças e/ou de temores. E isso porque "sabemos que [com] a biotecnologia tudo mudará, mas não sabemos como serão tais mudanças", pois "devido ao que se pode perder, trata-se do maior risco que o gênero humano já enfrentou", sobretudo se levarmos em conta que "o máximo perigo reside em que o poder de decisão sobre o que devemos fazer está nas mãos de quem é movido por interesses que não são ou não são eminentemente - aqueles de quem aponta esses riscos ou visa ao seu controle" (Maliandi \& Thüer, 2008: 234-235).

Por isso, a biotecnociência pode ser encarada como um "novo e desconcertante desequilíbrio etológico" e um "imenso risco social", visto que 
se trata sempre também de uma forma de poder (e de biopoder), diante do qual seriam necessárias duas atitudes: "a vontade de minimizar os conflitos (evitando-os, resolvendo-os ou regulando-os) e o reconhecimento de que todo o social está estruturado de maneira conflituosa" (Maliandi \& Thüer, 2008: 238-239).

Resumindo, se é verdade, por um lado, que "a rapidez do progresso tecnológico, em particular do progresso biotecnológico, tem semeado desordem em nossas categorias morais", por outro "os novos procedimentos sempre provocam advertências alarmantes". Por essa razão, "os progressos na colheita e disseminação das informações, tornadas possíveis graças à biotecnologia, não se afastam de maneira radical dos temores conhecidos acerca da relação entre conhecimento e poder", visto que "se pode abusar de qualquer técnica e não há conhecimentos, nem informação, que não sejam suscetíveis de manipulação para fins moralmente ruins". Nesse caso, nossa tarefa deverá ser a de "ficarmos atentos e impedir tais abusos" (Harris, 1992: 235).

A biotecnociência pode ser chamada literalmente de revolução - no seu sentido de "reviravolta, alteração [das] condições políticas ou sociais, mas não necessariamente súbita, abrupta ou violenta" (Mautner, 2010g: 651) porque seu saber-fazer permite não só compreender e transformar os sistemas vivos e seus contextos naturais (como já sabia, em parte, fazer a tecnociência tradicional dos engenheiros), mas também - graças à reprogramação de sua informação e constituintes - adaptá-los às necessidades, desejos e projetos humanos, inclusive quando isso implica reprogramar o próprio agente da reprogramação: o homem.

Concretamente, a medicina genômica permite ampliar as possibilidades diagnósticas, preventivas e preditivas, revolucionando, dessa maneira, a concepção e o campo da saúde humana, e talvez até a própria compreensão que o ser humano tem de si. Mas é também uma constante da história humana que uma revolução cultural - científica ou não - polarize a opinião e a percepção dos especialistas e do público em geral entre aqueles que veem na revolução em questão uma razão para grandes esperanças e aqueles que, ao contrário, a percebem com profunda apreensão. Assim aconteceu historicamente com a revolução copernicana, com a darwiniana, com a freudiana, e agora parece estar 
acontecendo com a revolução biotecnocientífica, pois o fenômeno constituído pela vigência do paradigma biotecnocientífico é motivo de esperanças e de temores.

De fato, para uns, especialmente para aqueles que têm a qualidade de suas vidas comprometida por doenças e moléstias de origem genética e, por isso, acreditam que os progressos da biotecnociência poderão evitar em grande parte essa condição de desvantagem comparativa perante seus semelhantes sadios -, a revolução biotecnocientífica é motivo de esperança. Ademais, para essa categoria de pessoas - que indicamos acima com o termo tecnofílicos é também lógico que a competência biotecnocientífica seja vista como uma dádiva; portanto, como uma ferramenta moralmente legítima a ser utilizada, e, por isso, é possível que a "mãe natureza" seja vista menos como uma boa mãe e mais como uma madrasta. Para outros, a revolução biotecnocientífica é também motivo de apreensão, quando não de verdadeiro temor, sobretudo para aqueles que, em princípio, não têm nenhum motivo sério para queixas quanto à sua saúde e à qualidade de sua vida (e à "mãe natureza"). Para essa categoria de pessoas, que indicamos com o antônimo tecnofóbicos, a revolução biotecnocientífica é tida prevalentemente como um grande risco, aparentemente não indispensável, e como uma interferência arriscada e perigosa nos complexos e delicados processos naturais, construídos "sabiamente" ao longo dos milênios pela "mãe natureza". Pode, portanto, revelar-se coisa de aprendizes de feiticeiros, incapazes de controlar as consequências de seus atos, como bem indicado pela expressão playing God - muitas vezes traduzida impropriamente por "brincar de Deus" quando se deveria traduzir por "fazer o papel de Deus", isto é, criar -, que exprime de fato a transformação do Homo faber e sapiens em Homo faber, sapiens e creator (Anders, 1980).

No entanto, em ambos os casos surge também uma pergunta de forte conteúdo especificamente moral: será que o humano não deveria pagar o preço de sua liberdade para essa "ousadia", isto é, arcar com as consequências de suas escolhas como ser que tem os meios para construir o mundo não necessariamente conforme as leis naturais, mas sim de acordo com as normas culturais e os projetos humanos de melhoria do bem-estar? Afinal, viver é correr riscos, e o risco zero é uma situação ideal que nunca existiu, como já tentavam mostrar a mitologia e o pensamento mitopoiético antigos ao falarem 
da condição edênica (se considerarmos o conto da expulsão do Éden). Portanto, o risco faria parte da própria estrutura da liberdade humana, razão pela qual não haveria nenhum argumento substantivo capaz de legitimamente exigir tal ausência de risco no caso da revolução biotecnocientífica, sobretudo tendose em conta seus enormes benefícios potenciais. É preciso, portanto, se dedicar ao difícil labor de ponderar riscos e benefícios em condições de incerteza (que abordaremos no terceiro ensaio desta coletânea, sobre as relações entre bioética e biossegurança).

\section{A questão da moralidade da engenharia genética}

Um dos produtos da biotecnociência que mais suscitam questionamentos de tipo moral é a engenharia genética, uma forma de saber-fazer que consiste em manipular a composição genética dos organismos vivos, graças à utilização das biotecnologias (eventualmente combinadas com as nanotecnologias), e em eliminar (ou pelo menos controlar) características não desejadas ou introduzir novas características desejadas. Quando o uso da engenharia genética resulta na combinação do material genético de organismos pertencentes a espécies diferentes, fala-se em organismos transgênicos (ou organismos geneticamente modificados, OGM), que são objeto de verdadeiras guerras políticas entre quem preconiza seu uso como resposta adequada às nossas necessidades - por exemplo, alimentares, para substituir tecnologias consideradas obsoletas ou para responder a necessidades de saúde - e quem, ao contrário, quer bani-los por considerá-los mera fonte de riscos e danos a serem absolutamente evitados.

Mas a competência em manipular organismos vivos a fim de melhorar suas qualidades em prol do bem-estar humano é tão antiga quanto a Revolução Agrícola, acontecida há mais de dez mil anos no Oriente Médio, onde o homem aprendeu intuitivamente e a partir da experiência a selecionar e cruzar animais e plantas para obter descendentes melhorados (por exemplo: mais produtivos e adaptados). Entretanto, seu planejamento racional só se tornaria possível graças aos avanços da biologia molecular a partir dos anos 1970, da genômica a partir dos anos 1990 e da nanotecnologia a partir do século XXI.

Do ponto de vista epistemológico, o surgimento da engenharia genética representa uma verdadeira transição paradigmática na maneira de pensar o ser vivo e de agir sobre ele. Com efeito, a vigência do paradigma 
biotecnocientífico pode ser vista como um desdobramento do próprio paradigma da vida (representado pela biologia) graças à integração do saberfazer tecnocientífico dos engenheiros aplicado aos sistemas vivos e a seus ambientes (que analisamos em detalhes no primeiro ensaio desta coletânea). Mas essa transição paradigmática, que atinge tanto o saber-fazer, representado pela biotecnociência, quanto o saber-agir (que tem implicações morais e políticas, ou - se preferirmos - bioéticas e biopolíticas), foi insuficientemente pensado tanto pela própria filosofia como pelas ciências humanas e sociais em geral, sendo quase sempre mostrado ou imaginado pela ficção científica e pelos meios da realidade virtual na forma de ameaças ou belas quimeras, sem entrar realmente no meio-campo constituído pela ponderação entre riscos e benefícios da maneira mais razoável possível.

Quando alguém tentou abordar essa transformação com seriedade, pensando, por exemplo, o sentido da revolução antropogenética nos termos paradoxais de uma crescente dependência da sobrevivência da espécie humana da revolução biotecnocientífica, por um lado, e dos custos dessa dependência, por outro - ou seja, da nova condição humana que consiste na intensificação da dependência da técnica, graças à qual o Homo sapiens passa da condição de criatura do mundo para aquela de criador de mundos (Sloterdijk, 2000) houve, sobretudo, reações de tipo emocional e pouco racionais. Nesse tipo de reação esquece-se de considerar, por exemplo, as qualidades emergentes e particularmente atuantes da verdadeira revolução na biosfera que permitiu o aparecimento do mamífero humano, chamado Homo faber e Homo sapiens, que tem se tornado um Homo creator.

De fato, faltou considerar as condições atuais do saber-fazer biotecnocientífico, as reais possibilidades e as implicações antropológicas e ecológicas das práticas desse novo tipo de ser, resultante da aliança entre a competência técnica do Homo faber e a competência racional do Homo sapiens, chamado também de Homo creator por ser capaz de produzir não só objetos, mas também entes vivos projetados, criados e consumidos. Faltou, em particular, aprofundar a análise da ambivalência perceptiva da competência biotecnocientífica do Homo creator, de suas práticas e seus produtos, que trazem para as sociedades contemporâneas o desafio de uma previsão talvez impossível e de uma avaliação de riscos e benefícios para os humanos (presentes e futuros). 
Por fim, faltou incluir, em tal análise, e sobretudo em seu cômputo final, os outros seres vivos e os ambientes, partindo da premissa - em parte resultante de constatações empíricas, em parte de pressupostos metafísicos - de que todos esses entes e seres estão vinculados uns aos outros e, portanto, são interdependentes, podendo então interagir em uma suposta grande, complexa e dinâmica cadeia do ser (ou "ser em devir").

Em outros termos, esse trabalho de análise paciente de um sistema hipercomplexo deve ainda ser feito à luz da competência e das performances implicadas na recente revolução biotecnocientífica, preocupando-se com a correta articulação da frágil condição biológica do humano ao nascer (neotenia) com a potência criadora e/ou destruidora do humano adulto, detentor do saber da linguagem e da técnica e, talvez, de alguma forma de sabedoria sobre o bem e o mal.

Embora esse trabalho de meditação sobre as implicações, tanto existenciais como morais e políticas, da biotecnociência fique em aberto, vale a pena lembrar alguns antecedentes na própria história da filosofia ocidental. Trata-se de pensadores que tentaram aprofundar as implicações existenciais e, em geral, filosóficas do mundo transformado pela tecnociência, como veremos a seguir.

\section{Breve histórico da conceituação de técnica pela filosofia}

A interrogação sobre a técnica na cultura ocidental é antiga. Platão já considerava a técnica como "o paradigma da relação que o homem estabelece com todos os objetos" e "procede do encontro de dois conhecimentos do objeto: o do artesão e o do usuário do objeto", mas vinculado ao conhecimento verdadeiro, julgado como "a única condição possível do domínio de qualquer atividade", sendo o primeiro conhecimento subordinado ao segundo (Brisson, \& Pradeau, 2010: 70-71). O filósofo sugeria também, no Protágoras, que a forma particular de ação humana chamada técnica seria um presente do titã Prometeu, que, comovido pela vulnerabilidade humana, teria dado ao homem a técnica de usar o fogo, roubando-o dos deuses e capacitando, dessa maneira, o humano tecnicamente. Ademais, no Eutidemo, Platão chamara a política considerada a atividade cidadã mais importante - de "técnica régia" (basiliké téchne) e usara a metáfora da técnica da tecelagem para indicar a essência da atividade de governar (Platone, 1974). 
Em realidade, o mito platônico remete, indiretamente, à própria neotenia humana, pois os humanos - pouco aparelhados no plano orgânico e desprovidos de meios suficientes de defesa ao nascer - seriam os únicos animais a não poder sobreviver sem instrumentos artificiais para aperfeiçoar sua natureza e não desaparecer. Esse mito tem, portanto, uma relação com a experiência, pois, ao nascer, o humano é um ser desamparado, imaturo e desprotegido em relação ao ambiente no qual terá que sobreviver, razão pela qual deverá ser inicialmente protegido para se manter vivo, até se tornar suficientemente capacitado para viver e tomar as decisões das quais em princípio dependerá sua qualidade de vida.

A técnica e a cultura em geral constituem as vantagens comparativas que nossa espécie construiu ao longo de sua história para compensar sua neotenia e sobreviver, tomar conta do mundo e transformá-lo conforme desejos e projetos, sensatos ou insensatos que sejam. Graças à revolução cultural representada pela emergência e afirmação do paradigma biotecnocientífico em meados do século $\mathrm{XX}$, o humano tornou-se capaz de reprogramar - como já vimos - o mundo vital (Lebenswelt), inclusive a si mesmo, o que podemos chamar de biotecnologização da vida. Assim, pode-se estabelecer um nexo entre a vulnerabilidade da condição humana, a criação dos meios sociais, técnicos e culturais do humano para contornar, de algum modo, a condição de vulnerabilidade e as formas de controle contra os abusos dos meios humanos aplicados ao mundo vital.

Mas é somente no século XX que uma reflexão consistente sobre a técnica se consolida, reconhecendo que as descobertas científicas e as inovações tecnológicas em qualquer campo da atividade humana têm não somente facilitado a vida dos humanos, mas também a transformado completamente. Por isso, tais descobertas e inovações são vistas como uma espécie de Jano de duas faces que ajuda o homem, mas a um preço considerado por alguns muito alto, pois poderia levar ao desaparecimento da liberdade e da própria vida orgânica como um todo (Schramm, 2000).

Diante desses riscos e/ou perigos, implicados pela competência biotecnocientífica, alguns filósofos têm feito uma reflexão não só sobre a atuação e o sentido das várias técnicas, mas também sobre a assim chamada "essência" da 
técnica e sobre como deveríamos lidar com ela, devido a seus possíveis efeitos negativos sobre o mundo vital e sobre a própria identidade do ser humano.

A seguir, apresentaremos a posição de quatro pensadores que se debruçaram sobre essas questões ao longo do século XX: Ernst Jünger (1895-2000), Martin Heidegger (1889-1976), Hans Jonas (1903-1993) e Arne Naess (1912-2009).

\section{A 'mobilização total' pela técnica de Ernst Jünger}

Jünger parte das noções nietzschianas de vontade de potência (Wille zur Macht) e ultra-homem (Übermensch) para indicar, com a primeira noção, a situação de movimento total e impessoal da técnica, e com a segunda o efeito de selecionar uma nova "raça" de humanos, capaz de fazer com que esse movimento total da técnica, em vez de aniquilar o homem, seja por ele vivenciado e dominado. Para indicar tal movimento, o autor utiliza o conceito de mobilização total (totale Mobilmachung), que seria a capacidade de pôr em movimento a totalidade de matéria e energia potencialmente disponíveis no universo. Como escreveu o autor, "a mobilização total se cumpre por ela mesma (...) ela é [a] expressão de uma lei misteriosa e inexorável [na qual] cada existência individual se torna, sem que o mínimo equívoco possa subsistir por muito tempo, uma existência de trabalhador" (Jünger, 1990: 113).

Para Jünger, essa mobilização total tornaria todos os humanos trabalhadores e só seria possível graças à técnica e ao aperfeiçoamento e desenvolvimento de tecnologias. Ademais, ela não seria um fenômeno casual e contingente, mas algo inevitável e necessário, inscrito na própria história da humanidade. Por fim, técnica e mobilização total implicariam a expropriação da liberdade, porque a técnica não seria algo possuído pelo homem como um instrumento em seu poder, mas por ser o próprio homem uma parte do processo técnico; em suma, porque seria a técnica a dominar o homem, e não o inverso.

A análise de Jünger destaca, com lucidez, o caráter potencialmente alienante do processo tecnológico, pois a técnica se imporia, de maneira inexorável, como uma necessidade, e o homem que nela se instala não poderia controlar plenamente nem suas regras e linguagens, nem seus efeitos. No entanto, o autor sugere que esse empoderamento técnico, indicado pelo termo tecnologia planetária (que será retomado por Heidegger, como veremos a seguir), teria 
necessariamente um preço alto, pois o ser humano deveria pagar seu bemestar e sua segurança com perda de sua liberdade e autonomia.

\section{A essência da técnica como Ge-stell de Martin Heidegger}

Impressionado com aquela que ele considerara uma das melhores compreensões da metafísica nietzschiana, Heidegger pensa que o conceito de mobilização total de Jünger permite enxergar o domínio da vontade de potência que, em sua forma técnica, teria adquirido - no século XX - uma dimensão planetária. Mas Heidegger pretende ultrapassar a análise de Jünger, introduzindo, em sua desconstrução metafísica, o conceito de verdade entendida como acontecimento (Ereignis) do ser, isto é, considerando o ser como aquilo que, por essência, se subtrairia ao controle do homem, mas, ao mesmo tempo, só se daria na relação com o homem, naquela que o autor chama clareira (Lichtung) em que pode colocar-se o "ser aí" (Dasein) do próprio homem. Esse acontecimento mudaria com o tempo e as épocas históricas - que correspondem às várias modalidades em que o ser se dá e ao mesmo tempo se subtrai -, e em época contemporânea essa manifestação do ser se daria no contexto da técnica.

Mas qual seria a essência da técnica?, pergunta Heidegger. E responde: o Ge-stell (neologismo que significa tanto composição como arrazoamento e armação, ou dispositivo), conceito ao qual o filósofo alemão chega depois de aplicar o método filológico à análise do verbo stellen (pôr, dispor), declinando as várias modalidades do dar-se da técnica de acordo com os vários significados de seus verbos compostos: vor-stellen (representar), be-stellen (ordenar, encomendar) e her-stellen (produzir), que seriam manifestações particulares (indicadas pelas preposições vor, be e her) de uma única atitude: aquela indicada pela semântica do verbo stellen, cujo significado revelaria a essência da técnica. Como explica o autor,

O ordenar (Be-stellen) põe. Provoca. Mas se o pensarmos em profundidade em sua essência, e não segundo seus possíveis efeitos, ordenar (...) passa rapidamente de um ordenável ao sucessivo [porque] tem antecipadamente trazido e posto tudo aquilo que está presente dentro da completa ordenabilidade, independentemente do fato de que, no caso individual, tal ente presente já se apresente de forma particular ou não. (Heidegger, 1994: 29) 
Entretanto, a vários aspectos dessa única atitude técnica corresponderiam significados distintos. Por exemplo, a técnica "provoca" na medida em que obriga algo a se manifestar, fazendo-o sair do estado de escondido, e para mostrar isso o autor cita o caso da Terra, a qual estaria instada a se apresentar em sua totalidade como recurso ordenável e explorável, não tanto pelo possível lucro almejado, mas, essencialmente, como algo ordenável. Portanto, esse ordenar em que tudo estaria ordenado em função de outro ordenar - se estabilizaria como algo efetivamente ordenado, logo como recurso subsistente ou fundo de reserva (Bestand). O próprio homem seria uma peça desse mecanismo do ordenar, embora tenha também um papel na atuação desse ordenar.

Diferentemente de Jünger, que destacara a ambiguidade da técnica como alienante e eventualmente controlável pelo ultra-homem nietzschiano, mas ao preço de sua liberdade, Heidegger faz um prognóstico mais pessimista sobre a possibilidade de a técnica ser controlada e dirigida pelo homem numa perspectiva não técnica. Por isso, não adiantaria nos opormos à técnica, visto que não podemos nos subtrair a seus dispositivos (a seu Ge-stell), pois, como evento extremo da metafísica ocidental, iniciada por Platão - a quem Heidegger "atribui a desvalorização dos objetos naturais e dos produtos humanos" (Steiner, 2001: 233) -, e que reduziria todos os seres a meros entes, a técnica deveria ser deixada ao seu destino - o qual seria também o nosso sem se pretender mudá-la.

Entretanto, essa meditação de Heidegger sobre a essência da técnica e as modalidades de seu revelar-se é bastante obscura e indica o contexto niilista (já presente em Jünger) das discussões sobre tecnociência e biotecnociência que se seguiriam, pois muitas das análises posteriores sobre o niilismo tecnocientífico se inspiram na meditação heideggeriana. De fato, Heidegger afirma que a técnica em sua forma atual - conhecida a partir dos anos 70 do século XX como tecnociência - seria a metafísica realizada de nosso tempo, pois reduziria a totalidade da Lebenswelt (mundo da vida) a um mero fundo de reserva, graças à potência do agir racional, técnico e operacional.

Mas o autor passa, sem mais, dessa descrição sobre a essência da técnica que pode eventualmente ser aceita como uma ontologia da técnica, embora seja certamente também uma preocupação metafísica - para outro plano, o 
existencial. Nesse plano se daria a submissão inevitável do homem contemporâneo à racionalidade tecnocientífica, o que consistiria, em substância, em subsumir o universo dos fins ao dos meios, pois isso seria um destino (Geschick), o que implicaria o aniquilamento da liberdade de escolha (como já indicado por Jünger).

Para caracterizar essa condição existencial do homem contemporâneo, Heidegger indaga aquela que chama de essência da técnica, indicada - como já vimos - pelo neologismo Ge-stell. Mas essa essência da técnica implicaria uma condição niilista, ou seja, uma "nadificação do Ser", em razão de sua objetivação técnico-metafísica, situação que poderia ser indicada pela expressão contraintuitiva "tudo aquilo que é tecnicamente possível fazer será necessariamente feito" (independentemente de esse fazer poder ser considerado um bem ou um mal).

Porém, quem não aceita essa aniquilação da dimensão ética, implicada pelo imperativo tecnológico niilista, muitas vezes permanece prisioneiro dessa mesma lógica, pois pensando combater tal niilismo - e os supostos abusos da tecnociência implicados - simplesmente inverte o sentido da expressão, considerando, sem mais, que "nem tudo aquilo que é possível fazer deve ser feito", ficando, portanto, muito aquém da discussão crítica instigada pelas posições do autor.

Em uma avaliação crítica da meditação heideggeriana, uma das objeções que podem ser feitas - sobretudo a partir da vigência do paradigma biotecnocientífico atual - é que sua análise sobre a essência da técnica resulta não de uma subsunção dos fins aos meios, mas, mais diretamente, em uma confusão entre meios e fins. Isso talvez explique o fato de Heidegger nunca ter proposto explicitamente uma ética em seu sistema filosófico, a não ser algumas considerações éticas gerais contidas na Carta sobre o Humanismo, de 1949, que inauguraria de fato "um campo de pensamento trans-humanista ou pós-humanista" (Sloterdijk, 2000: 22). Uma dessas considerações éticas gerais pode ser inferida, por exemplo, de sua preocupação de "superar a metafísica", a qual pode ser vista como "simultaneamente e em última instância um chamamento para 'salvar a terra', precisamente porque a tecnologia exploradora e o culto da ciência, supostamente objetiva, representam a culminação natural da metafísica ocidental a partir de Platão" (Steiner, 2001: 237). 
Aplicando a reflexão heideggeriana ao caso específico da biotecnociência, pode-se dizer que a confusão se dá entre seus meios - como aqueles da engenharia genética - e os fins correlacionados, representados pela procura do bem-estar e da melhoria da qualidade de vida dos sujeitos necessitados e que poderiam recorrer a ela. Com efeito, se o arrazoamento (Ge-stell) parece ser, por um lado, necessário para explicar como se aprende a utilizar determinada técnica - visto que sempre teremos que nos submeter a determinadas condições para seu uso correto (e isso vale para aprender a dirigir, utilizar um computador, falar uma língua, aprender uma especialidade como a engenharia genética nas faculdades de biologia, tomar um remédio, lidar com as pessoas etc.) -, por outro já nesse nível de aprendizagem uma dinâmica muito sutil entre tentativas e erros implica, muitas vezes, atos de autêntica criatividade, que consistem em descobrir novas maneiras de utilizar uma técnica ou uma linguagem específica já existente. Em suma, a relação entre meios e fins pode muito bem ser vista como da ordem de uma dialética, mais que daquela do imperativo tecnológico e do consequente niilismo tecnocientífico subjacente. De acordo com "a densa idiossincrasia do estilo tardio de Heidegger" (aquele do ensaio sobre a técnica, publicado em 1953), "superar a metafísica" e "salvar a terra" são chamamentos inseparáveis, pois "na mesma época do mecanismo niilista, a esperança volta a ser acessível", como parece mostrar a referência ao poeta Hölderlin, com a qual Heidegger conclui seu ensaio: “Onde está o perigo, cresce também o que pode salvar" (Steiner, 2001: 237).

Entretanto, por dever deimparcialidade, deve-se dizer também queas análises de Heidegger tiveram o mérito de apontar o fato de a ciência contemporânea ser inseparável da técnica; isto é, de toda ciência ser inexoravelmente uma tecnociência; um saber que é ao mesmo tempo um fazer, ou uma competência simultaneamente racional, técnica e operacional. Essa caracterização da ciência contemporânea como um saber que é de fato sempre um saber-fazer, isto é, um dispositivo que tem uma dimensão intrinsecamente pragmática, permite que se analisem seus fatos (como aqueles da engenharia genética) do ponto de vista moral. Por exemplo: aplicando-se as ferramentas analíticas e normativas da bioética à atuação do paradigma biotecnocientífico, visto que a bioética estuda inter alia justamente a nova forma da práxis humana na vigência do paradigma biotecnocientífico, cujos fatos se tornam objetos legítimos de análise por parte 
da ética porque se referem diretamente aos efeitos - considerados benéficos ou maléficos - das ações sobre outros humanos e os seres vivos em geral.

De fato - e de acordo com o paradigma bioético (Hottois, 1990) -, se pensarmos nos efeitos irreversíveis, reais ou potenciais, da vigência da biotecnociência, veremos que não se pode mais falar impunemente na neutralidade da ciência, visto que justamente "a ciência tem se tornado um meio da técnica" (Ellul, 1954: 8), podendo, portanto, agir sobre a própria estrutura da vida e, talvez indiretamente, sobre o tipo de escolha humana, ou de sociedade e de instituição desejáveis. Aliás, é por isso que existe, além de uma filosofia da ciência (que se ocupa da consistência e da fidedignidade das hipóteses e teorias científicas), uma sociologia da ciência (que se ocupa das implicações sociais desse saber-fazer) e, sobretudo, uma bioética da ciência (que se ocupa das implicações morais do saber-fazer tecnocientífico e biotecnocientífico) e uma biopolítica da ciência (ou aplicação dos dispositivos políticos à humanidade como espécie).

Portanto, para evitar tanto a ideologia do endeusamento beato da ciência dos tecnofílicos quanto a ideologia tecnofóbica de sua demonização - que indicamos pela imagem mitológica do Jano de duas faces -, devemos saber distinguir não só os meios e os fins, mas também os fatos e os valores, pois sem essa distinção renunciaríamos à prática da crítica em prol da mera aceitação ou recusa ideológica (ou emocional) da ciência transformada em tecnociência e biotecnociência. Tal preocupação crítica implica, ainda, termos provavelmente que renunciar às visões holísticas da ciência - que não sabem identificar e definir esse todo que a ciência é - em prol de uma visão complexa, a qual permite saber "distinguir sem separar e juntar sem confundir" seus vários aspectos entrelaçados (Morin, 1990).

Quem irá introduzir, de forma explícita, a meditação sobre as implicações morais e éticas da vigência da biotecnociência será um ex-aluno de Heidegger: Hans Jonas.

\section{Hans Jonas e o 'princípio responsabilidade’ na Idade da Técnica}

O pensamento de Jonas se inscreve naquele movimento de "transformação da filosofia", resultante da "confrontação entre a pergunta hermenêutica 
pelo sentido do ser e a crítica do sentido da linguagem, efetuada pela filosofia analítica" (Apel, 2000: 9), conhecido também como filosofia prática. Na cultura alemã, tal movimento surge durante os anos 60 do século XX e está preocupado com a dimensão concreta do agir humano e com o tipo de racionalidade que $o$ sustenta, partindo dos pressupostos de que o homem não só pensa e observa, mas, sobretudo, age, e ao agir utiliza técnicas de vários tipos que afetam - ou podem afetar - outros humanos, outros seres vivos, os ambientes naturais, podendo, inclusive, "mudar o universo" (Sulston, 2007: 17). Portanto, seu comportamento tem consequências importantes sobre o bem-estar e a qualidade de vida dos outros (amplamente entendidos: outros humanos e seres vivos em geral) e de si mesmo, tornando-o, assim, responsável por seus atos e suas consequências.

Em uma publicação autobiográfica, o autor revela que sua preocupação com a problemática da técnica se deve, sobretudo, ao fato de esta - segundo a lição heideggeriana - ter transformado o saber científico, antes entendido como mera teoria, em um saber-fazer técnico, que é "eminentemente prático [e] determina cada vez mais a vida de todos nós", razão pela qual deveríamos considerar atentamente esse aspecto preocupante, "para que ele não se transforme, para nós, em um destino que, sem nos darmos conta, temos procurado". Isso o teria "obrigado a passar da razão teórica à razão prática, isto é, à ética", em que não é mais "o prazer do conhecimento, mas o medo do futuro ou a preocupação para com o homem" que motivam o pensamento entendido como "um ato de responsabilidade" (Jonas, 1987: 26).

$\mathrm{Na}$ avaliação de Jonas, na idade de vigência da técnica moderna - e tendo em conta seus efeitos a longa distância e a longo prazo sobre o mundo vital - a própria natureza do agir humano teria mudado substantivamente, e, portanto, também a responsabilidade pelos seus atos. Para o autor, isso exigiria uma transformação na própria concepção do papel da ética, a qual teria a tarefa autocrítica de questionar seu antropocentrismo, o pressuposto da natureza imutável da natureza humana e o quadro temporal limitado das consequências da ação, pois o campo de ação da técnica abrangeria hoje o inteiro espaço da biosfera e já teria produzido danos irreparáveis no ambiente. Por isso, argumenta Jonas, surgiria a questão pertinente e legítima do valor moral da natureza, que a ética contemporânea não poderia esquecer e deixar de abordar. 
Para Jonas, dever-se-ia considerar que a técnica aplicada ao mundo vital colocaria em questão o pressuposto fundamental da moral - a imutabilidade e intangibilidade da natureza humana - porque hoje já sabemos e podemos intervir tecnicamente sobre o patrimônio genético humano e transformar, de maneira significativa e irreversível, as estruturas biológicas, os corpos e, talvez, as mentes. Em outros termos: o homem já poderia assumir sua própria evolução, e isso demandaria saber se o humano atingirá o patamar do alémhumano (ou além-do-homem) nietzschiano (já indicado por Jünger), "capaz de dizer Sim a todas as coisas" e, portanto, de "autossuperação" (Tanner, 2004: 74-76). Mas, nesse caso, deveríamos nos perguntar que sentido teria uma ética humana que analisasse a prática de quem decidiu as transformações a serem feitas no genoma humano, tendo em conta o argumento prudencial referente à imprevisibilidade incontrolável da ação tecnológica, a qual faria - segundo a visão de Jonas - aumentar a probabilidade de insucesso mais do que aquela do sucesso.

Em sua obra mais conhecida, O Princípio Responsabilidade, Jonas ([1979] 2006) aprofunda sua análise e argumenta que, pela primeira vez na história da humanidade, devemos considerar seriamente a hipótese do aniquilamento de toda forma de vida no planeta Terra. E que, consequentemente, devemos também nos perguntar sobre a moralidade da transformação da natureza humana, devido ao uso, cada vez mais intensivo, da técnica, capaz de modificar a própria identidade orgânica e, talvez, psíquica do Homo sapiens, que - como já lembramos - deve ser visto também - e simultaneamente - como Homo faber e Homo creator.

Em realidade - para Jonas - e ao contrário do que comumente se pensa, o Homo faber já teria ultrapassado o Homo sapiens:

Hoje, na forma da moderna técnica, a techne transformou-se em um infinito impulso da espécie para adiante [e essa] conquista de um domínio total sobre as coisas e sobre o próprio homem surgiria como a realização de seu destino. Assim, o triunfo do homo faber sobre o seu objeto externo significa, ao mesmo tempo, o seu triunfo na constituição interna do homo sapiens, do qual ele outrora costumava ser uma parte servil. (Jonas, [1979] 2006: 43) 
Mas essa superação da competência racional pela competência técnica implicaria a ideia de que "a tecnologia assume um significado ético por causa do lugar central que ela agora ocupa subjetivamente nos fins da vida humana", pois

sua criação cumulativa, isto é, o meio ambiente artificial em expansão, reforça, por um contínuo efeito retroativo, os poderes especiais por ela produzidos, [exigindo seu] emprego inventivo incessante [para] manterse e desenvolver-se, recompensando-o com um sucesso [que] contribui para o aumento de suas ambições. (...) $\mathrm{Na}$ imagem que [o homem] conserva de si mesmo [ele] é cada vez mais o produtor daquilo que ele produziu e o feitor daquilo que ele pode fazer; mais ainda, é o preparador daquilo que ele, em seguida, estará em condições de fazer. Mas quem é "ele"? Nem vocês nem eu: importam aqui o ator coletivo e o ato coletivo, não o ator individual e o ato individual; e o horizonte relevante da responsabilidade é fornecido muito mais pelo futuro indeterminado do que pelo espaço contemporâneo da ação. Isso exige imperativos de outro tipo [e] a moralidade deve invadir a esfera do produzir, da qual ela se mantinha afastada anteriormente, e deve fazê-lo na forma de política pública [pois] a natureza modificada do agir humano altera [também] a natureza fundamental da política. (Jonas, [1979] 2006: 43-44)

Para dar conta dessa nova situação existencial, a ética tradicional seria insuficiente. Para Jonas, o segundo imperativo categórico kantiano formulado na Metafísica dos Costumes - "Age de modo tal que uses a humanidade tanto em tua pessoa como na pessoa de todo outro sempre ao mesmo tempo como fim, jamais simplesmente como meio" - se mostraria insuficiente por ser fundamentalmente o princípio de uma ética da reciprocidade entre aqueles que compõem a sociedade humana: ao dever de um corresponde o direito de outro, e vice-versa. Mas a ética da reciprocidade não seria mais válida - argumenta Jonas - quando entram em jogo as gerações futuras, que não podem reivindicar diretamente seus direitos, o mesmo acontecendo com animais e outros seres vivos, embora tenhamos deveres específicos para com eles.

Por essas razões, à ética da reciprocidade Jonas opõe uma ética da responsabilidade, segundo a qual nós somos responsáveis pelas nossas escolhas, inclusive com relação àqueles que não podem (ainda) fazer valer seus direitos.

Quase duas décadas depois, Jonas publica uma aplicação do princípio de responsabilidade à prática da biomedicina - Ética, Medicina e Técnica - em que pondera: 
Limito-me a indicar o princípio da ordem de preferência: quanto mais pobres em conhecimento, motivação e liberdade de decisão forem os indivíduos (...), tanto mais parcimoniosamente e mesmo relutantemente deveria a provisão deles ser usada, e tanto mais imperativa tem pois de tornar-se a ordem de razões em contrário.

Note-se que isto é o oposto de um padrão de utilidade social, o inverso do ordenamento por "disponibilidade e sacrificabilidade": os elementos mais valiosos e escassos, menos sacrificáveis, do organismo social hão-de-ser os primeiros candidatos ao risco e ao sacrifício. É o padrão da noblesse oblige; e com toda a sua antiutilidade e aparente "prodigalidade", pressentimos nela uma rectidão e talvez mesmo uma superior "utilidade", pois a alma da comunidade é pelo espírito que vive. É também o oposto daquilo por que clamam os interesses quotidianos da investigação, e para que a comunidade científica lhe faça as honras é mister que lute contra a forte tentação de se dirigir, por inércia, às fontes de suprimento mais à mão - aqueles que são mais sugestionáveis, mais ignorantes, mais dependentes, que mais "amarras" têm em vários sentidos. Não creio que uma resistência intensificada deva aqui estropiar a investigação, o que não pode ser permitido; mas pode efectivamente abrandá-la pelos menores números que em consequência disso irão alimentar a experimentação. Tal é o preço - uma vez mais brando coeficiente de progresso - que poderá ter de ser pago pela preservação do mais precioso capital de uma superior vida comunitária. (Jonas, 1994: 150-151)

\section{Comparando as três posições}

Na comparação das posições dos três autores citados, pode-se constatar que todos expressam um sentimento de desamparo, e de quase impotência, em relação ao poder considerado impessoal e incontrolável da técnica. Mas a posição de Jonas é a única das três que expressa claramente (diferentemente de Heidegger, que a deixa somente aparecer metaforicamente como uma esperança ante o perigo) uma possível solução com sua proposta de uma ética da responsabilidade. Esta - em nossa leitura - estabelece as condições de possibilidade para uma vinculação do paradigma biotecnocientífico com o paradigma bioético, a qual implicaria uma reformulação do pensamento filosófico tradicional para se pensar em uma nova convivência possível - e não catastrófica - entre homem, natureza e técnica, dirigida por humanos que devem necessariamente ser responsáveis. 
Em realidade, como vimos, para Jonas - contrariamente a Heidegger a técnica não é, em si, nem boa nem má, pois quando foi bem utilizada permitiu uma efetiva melhora das condições de vida dos humanos (como mostra, por exemplo, boa parte da história da medicina). Mas isso não permite idolatrá-la como um instrumento capaz de resolver todos os problemas, porque o desenvolvimento tecnológico já tem tido também consequências devastadoras - por exemplo, para o ambiente natural - e claramente imorais, inclusive na própria medicina, como no caso dos médicos que atuaram durante a vigência de biopolíticas de extermínio. De qualquer maneira, a técnica teria transformado radicalmente a condição humana, e isso implicaria também uma reformulação da ética, tanto no sentido de um aprofundamento das questões inéditas trazidas pela vigência do paradigma biotecnocientífico quanto no de uma ampliação inédita do campo da moralidade, pela inclusão de novos sujeitos, como o mundo humano futuro, o mundo animal e o ambiente natural, lídimos objetos (ou destinatários) da aplicação do paradigma bioético atualmente.

\section{A 'ecologia profunda' de Arne Naess}

Sobre essa ampliação do campo da consideração moral - e tendo-se em conta a pertinência e a legitimidade de se aplicar a ética às questões ambientais -, devemos lembrar brevemente outro autor, o filósofo norueguês Arne Naess, formulador da ecologia profunda (deep ecology), abordada em um artigo de 1973 e desenvolvida no livro Ecologia, Comunidade e Estilo de Vida (Naess, 1989). Nessa obra, o autor opõe ao tradicional antropocentrismo - que já havia sido criticado por suas limitações, inclusive por Jonas, mas que Naess considera como "o sintoma de um mal mais profundo: o individualismo" e segundo o qual "a realidade é constituída, em última instância, de seres independentes uns dos outros" (Goffi, 2001:352). Em substituição, Naess propõe uma ecosofia capaz de superar o antropocentrismo vigente mediante um biocentrismo segundo o qual a vida como tal teria valor intrínseco, ou seja: todas as formas de vida, e não somente as humanas, teriam o igual direito de existir e de se realizar plenamente. Tal biocentrismo levaria, para Naess, a um igualitarismo biosférico, pois todos os seres vivos estariam de fato conectados entre si como os nós de uma rede, e a qualidade de vida de uma forma viva dependeria da relação instaurada com as outras formas de vida, o homem sendo nada mais 
que um desses nós, apesar de suas especificidades. Isso implicaria novos estilos de vida, mais frugais, isto é, caracterizados pela simplicidade dos meios e pela riqueza dos fins, fundados em uma nova forma de sabedoria relativa ao oikos ou casa-Terra.

É a essa posição que o autor chama de ecologia profunda (deep ecology), contraposta à tradicional ecologia superficial (shallow ecology), a qual só se preocuparia com a poluição ambiental e a finitude dos recursos naturais, conservando substancialmente os padrões de vida e de consumo dos habitantes dos países desenvolvidos. A ecologia profunda, por sua vez, seria capaz de originar uma igualdade de direitos entre todas as formas de vida da biosfera, o que poderia implicar termos que pensar seriamente em modificar tais padrões, inclusive abandonando o ponto de vista antropocêntrico, incapaz de considerar devidamente os outros seres e sistemas vivos integrados no cosmos.

Para o autor, esse igualitarismo entre espécies teria profundas implicações morais, pois

O movimento da ecologia profunda [implica]: (a) A rejeição da imagem do homem-no-ambiente em prol da imagem relacional a todo campo [e] (b) O igualitarismo biosférico - em princípio. A cláusula "em princípio" está inserida porque qualquer práxis realística implica necessariamente alguma matança, exploração e supressão. [Mas para] o trabalhador em campo ecológico o igual direito a viver e a se realizar plenamente é um axioma valorativo intuitivamente evidente e óbvio. Sua restrição aos seres humanos é uma forma de antropocentrismo que tem efeitos prejudiciais para a qualidade de vida dos próprios seres humanos. Essa qualidade depende em parte do prazer profundo e satisfação que recebemos da nossa parceria com outras formas de vida. A tentativa de ignorar nossa dependência e de instituir uma relação do tipo patrãoescravo tem contribuído para a alienação do homem de si mesmo. (Naess, 1989: 28)

Feitas essas considerações histórico-conceituais (ou genealógicas) sobre a percepção de alguns filósofos da identidade da revolução biotecnocientífica e com Jonas e Naess - sobre as consequências para uma suposta nova identidade da ética, mais ampla e integrada, podemos apresentar os principais argumentos em jogo quando se enfoca a moralidade dos atos biotecnocientíficos. 


\section{A Moralidade da Revolução Biotecnocientífica}

Como já lembramos, historicamente toda revolução, tanto social como cognitiva, sempre constituiu uma ruptura com os padrões culturais e comportamentais vigentes na época em que surgiu, razão pela qual não há, em princípio, nenhum motivo para que isso não devesse acontecer também com a revolução biotecnocientífica em curso. Mas, diferentemente do caso das revoluções científicas anteriores, com a vigência do paradigma biotecnocientífico temos algo inédito, pois parece ser a primeira vez na história humana que o homem tem não só o poder de transformar o mundo respeitando suas estruturas, mas também o de criar novas estruturas vivas e, sobretudo, de se modificar e autocriar, inclusive no sentido de se tornar uma nova espécie, supostamente mais adaptada ao seu meio em transformação - logo, de transformar potencialmente a própria estrutura do humano, inclusive a forma do juízo moral.

Porém, aqui surgem imediatamente também novas perguntas. Por exemplo: nessa nova condição antropológica, será que o Homo sapiens - que é também Homo faber e Homo creator - está evolutivamente preparado para essa nova capacitação e o novo tipo de responsabilidade decorrente? Ou - perguntando de outra maneira - será que ele sabe com suficiente certeza o que está fazendo e o que isso implica em termos de consequências não só imediatas, mas também futuras? Afinal, não é dito que ao novo poder de atuar, adquirido pela competência biotecnocientífica, corresponda uma nova competência moral que seja adequada aos desafios morais apresentados pela primeira. Ao contrário, pode muito bem ser que à potência e ao poder do saber-fazer biotecnocientífico corresponda uma incompetência do ponto de vista ético; ou seja, que o Homo faber sapiens e creator, competente do ponto de vista biotecnocientífico, seja de fato um Homo faber sapiens e creator que é também - como já vimos demens do ponto de vista moral.

Trata-se de questões evidentemente complexas e problemáticas, que mereceriam uma abordagem atenta a suas características e inter-relações. De fato, a biotecnologização do mundo vital tornou-se objeto de estudo, de questionamentos e de tomadas de posição bastante radicais, que configuram um campo discursivo bastante reduzido e polarizado entre dois tipos de destinatários: os que estariam sendo supostamente beneficiados e os prejudicados - 
apontando, assim, para uma ambivalência estrutural em sua percepção (que já indicamos pela imagem do Jano de duas faces). Em outras palavras, o processo sociocultural que leva o Homo faber sapiens da situação de desamparo à competência e às performances de Homo faber-sapiens-creator traz, para nós, contemporâneos, a suspeita de que essa nova competência humana se daria no contexto de uma equiprobabilidade de o ser humano ser Homo sapiens sapiens e Homo sapiens demens.

Entretanto, esse tipo de percepção (embora não referida explicitamente à suposta condição humana do Homo creator) é tão antigo quanto o antigo pensamento mitopoiético (recuperado pela literatura e, sobretudo, pelo cinema), que é o pensamento pré-racional que antecede o surgimento do pensamento sistemático e ordenado pelo logos, chamado filosofia, a qual, por sua vez é bom lembrar -, nasce também do espanto em relação ao desconhecido e ao impensado, mas, ao mesmo tempo, tenta detectar seu significado pela ordenação, descrição e compreensão dos construtos simbólicos e imaginários do humano.

Mas quais são, nesse novo contexto, os argumentos pró e contra os atos biotecnocientíficos e, em particular, contra os feitos da engenharia genética, em razão de seus possíveis efeitos sobre o real como um todo e sobre a vida humana em geral?

\section{A moralidade da intervenção programada sobre o genoma humano}

Como vimos, a expressão moralidade da engenharia genética é entendida aqui - de acordo com o significado técnico do termo moralidade, dado no começo deste ensaio - como análise crítica e normativa não somente dos efeitos positivos e moralmente aceitáveis da intervenção programada sobre o genoma humano, mas também dos negativos. Ou seja, o termo moralidade se refere ao conjunto de argumentos morais pró e contra a utilização da engenharia genética, argumentos baseados em escalas de valores e teorias morais não necessariamente (ou a priori) compatíveis entre si, sem, com isso, excluir a possibilidade de acordos e compromissos a posteriori.

Entrando mais nos detalhes, pode-se dizer que, via de regra, não existem argumentos morais substantivos contra a engenharia genética aplicada a 
plantas e animais não humanos, a não ser o argumento antigo (de origem aristotélica) - considerado por muitos como autoevidente-de que a engenharia genética estaria sempre e intrinsecamente errada porque interferiria no suposto finalismo intrínseco aos sistemas vivos (o que não passa de uma petitio principii questionável). Ou, então, o argumento utilitarista-consequencialista da necessária prudência e do obrigatório respeito aos padrões de biossegurança, que visariam, ambos, a garantir as melhores consequências mediante a ponderação de riscos e benefícios (o que analisamos detalhadamente no terceiro ensaio desta coletânea comparando as ferramentas da bioética com aquelas da biossegurança).

Objeções morais aparentemente mais substantivas surgem no caso da engenharia genética aplicada aos organismos humanos, sobretudo para fins melhorativos, facilmente associada a políticas eugenistas consideradas injustas porque discriminatórias, o que implica a necessária prudência diante de tais possibilidades biotécnicas transformadas em dispositivos biopolíticos e de biopoder. Porém, mesmo quando a objeção é fundamentada na prudência, o discurso não é muito claro, pois os argumentos racionais são dificilmente distinguíveis das emoções, razão pela qual é indispensável analisar os argumentos racionais separadamente, distinguindo os prós e os contras e explicitando sua eventual cogência, antes de tentar relacioná-los com suas expressões emocionais.

\section{Os argumentos favoráveis e contrários}

Em síntese, os argumentos a favor da aplicação da engenharia genética destacam suas potencialidades benéficas para prevenir e curar doenças e moléstias, ou para melhorar aptidões humanas consideradas desejáveis ou boas, e que constituiriam uma espécie de aprimoramento das capacidades humanas. Por sua vez, os argumentos contrários sublinham as potencialidades maléficas, visto que a engenharia genética poderia ser utilizada, por exemplo, para criar uma linhagem de super-humanos, supostamente capazes de escravizar o resto da população demasiado humana, ou para programar políticas discriminatórias aplicadas aos portadores de doenças e moléstias, ou simplesmente aos diferentes, como mostrariam as políticas e biopolíticas de tipo eugenista já adotadas no passado. Mas, nesse caso, haveria tanto um desrespeito 
injustificado à dignidade humana e à autodeterminação pessoal quanto alguma forma de injustiça social, visto que a programação genética poderia instaurar uma relação assimétrica e paternalista, na qual

o programador do programa dispõe, de maneira unilateral, sem ter pressuposto, de maneira justificada, o menor consentimento, sobre o material genético de outra pessoa com a intenção paternalista de colocar nos trilhos corretos a biografia desta outra pessoa, que dependerá desta intenção. (Habermas, 2001: 111)

Outra controvérsia diz respeito aos direitos das gerações futuras. Nesse caso, quem é contrário à engenharia genética argumenta que esta infringiria o direito fundamental - dos humanos por vir - a um genoma não manipulado, ao passo que para seus defensores a engenharia genética poderia ser o único meio de assegurar a sobrevivência da espécie em condições adversas no futuro. Mas, aqui, existe o problema de saber como atribuir direitos sem a contrapartida dos deveres, razão pela qual se pode argumentar que o termo direitos, aplicado a sujeitos potenciais, tem, na melhor das hipóteses, um sentido meramente analógico, embora Hans Jonas (2006) já argumentasse no sentido de deveres para com sujeitos de direitos ainda não existentes.

\section{Os referenciais deontológicos, teleológicos e utilitaristas}

Os argumentos pró e contra o uso das ferramentas biotecnocientíficas pertencem, substancialmente, a três tipos de teorias morais:

1) As deontológicas, que se referem às obrigações relativas aos deveres do agente moral e, em particular, aos deveres dos profissionais, inclusive em nosso caso - dos profissionais da engenharia genética, e aos limites decorrentes a serem eventualmente impostos à prática da manipulação genética. Entretanto, as deontologias não respondem satisfatoriamente à pergunta "por que devemos agir moralmente de determinada maneira em determinada situação específica?", a qual pode afetar diretamente a análise e entrar em conflito com algum outro dever (como no caso dos dilemas morais conhecidos como escolhas de Sofia).

2) As teleológicas, que se referem aos supostos fins ou desígnios (ou causas finais) dos organismos e sistemas naturais, e que os consideram pertinentes para avaliar as ações, que serão julgadas positivas ou negativas 
de acordo com suas consequências, ponderando, por exemplo, se a manipulação genética respeita ou não o finalismo intrínseco, ou telos, dos processos naturais. Entretanto, também as teleologias têm seus limites, pois não conseguem explicar suficientemente por que os processos e as coisas teriam causas finais.

3) As utilitaristas, que podem ser vistas como um desdobramento (ou subconjunto) das teleológicas, as quais se referem substancialmente à utilidade social e consistem em ponderar a melhor relação possível entre probabilidades dos riscos e das esperanças dos benefícios, mas podem não ter em devida conta, por exemplo, os interesses das minorias (necessariamente subsumidos àqueles da maioria).

$\mathrm{Na}$ prática, os três tipos de argumento podem se tornar complementares quando se queira sair de um impasse e chegar a um acordo, isto é, quando a ética pretende encontrar convergências no ethos atravessado pela conflituosidade, para utilizar os termos de Ricardo Maliandi (2006). Por exemplo, quando os mesmos argumentos utilitaristas podem servir tanto para justificar quanto para condenar alguma intervenção no genoma, será preciso recorrer a argumentos adicionais, de tipo teleológico ou deontológico. De fato, como indicamos, o utilitarismo e o consequencialismo são muito próximos, pois o útil pode ser visto também como consequência de um ato, e a deontologia deverá, de algum modo, dialogar com o consequencialismo e o utilitarismo para não se restringir ao âmbito das boas intenções necessárias para respeitar deveres.

\section{Os argumentos a favor da intervenção sobre o genoma humano}

Os principais argumentos a favor da legitimidade moral da intervenção são os seguintes:

1) $O$ argumento terapêutico, com que se pretende legitimar a intervenção para a cura de doenças e moléstias, isto é, para eliminar um dano atual. Em particular, esse argumento legitima a intervenção sobre as células somáticas dos indivíduos existentes, na qual se tenta remover causas de sofrimentos considerados em princípio evitáveis. Trata-se de um argumento que podemos chamar de utilitarista negativo, e contra ele não 
parece haver contra-argumentos muito cogentes, visto que o argumento terapêutico é considerado perfeitamente razoável, pelo menos de um ponto de vista sanitário e pressupondo uma sociedade secular e laica na qual o martírio e a santidade constituem mais a exceção do que uma regra imposta a todos. Ademais, se não aceitássemos esse argumento, a rigor nenhuma intervenção médica seria legítima. No entanto, o argumento terapêutico deve enfrentar a questão de seus excessos, como a obstinação terapêutica contra qualquer tipo de doença e moléstia, o que pode resultar em uma espécie de medicalização de toda a sociedade ou em biopolíticas questionáveis, acrescentando, no mesmo movimento, mais sofrimento ao mundo.

2) $O$ argumento preventivista, com que se visa a legitimar a intervenção para prevenir doenças e moléstias. Podemos chamar também esse argumento de tipo utilitarista negativo, uma vez que a ele se recorre com a intenção de evitar danos futuros ou potenciais, o que é também em princípio razoável e moralmente defensável. Entretanto, nesse caso uma prevenção efetiva implicaria intervir também sobre a linha germinal para que as modificações introduzidas pela engenharia genética fossem transmitidas aos descendentes, isto é, agindo em prol de um possível maior bem-estar futuro, visto que poderiam propiciar uma descendência mais saudável ou, pelo menos, menos doente. E isso pode criar um verdadeiro dilema moral, pois se é razoável, por um lado, defender a intervenção sobre a linha germinal, considerando que serviria para eliminar danos e sofrimentos em princípio evitáveis, por outro, uma vez que as transformações - herdadas pelos descendentes - serão em princípio irreversíveis, podem surgir fortes dúvidas (e objeções) sobre riscos potenciais e a longo prazo, devido às próprias transformações genéticas introduzidas, que poderiam se revelar, afinal, iatrogênicas e sem volta. Há também os riscos biopolíticos e antidemocráticos de uma biocracia autoritária, como aquela que pretendesse impor estilos de vida ditos saudáveis a todos, e a eugenia, que pretende controlar ou melhorar a qualidade da descendência, mas pode implicar políticas discriminatórias como aquelas praticadas durante o nazismo. De qualquer maneira, é perfeitamente razoável defender a ideia de que não 
há nenhuma diferença relevante, no plano moral, entre intervenção sobre a linha somática e a linha germinal, desde que controlados os eventuais riscos, operação que - como vimos - é algo também incerto e questionável.

3) $\mathrm{O}$ argumento da beneficência e da não maleficência, com o qual se visa a legitimar a intervenção, porque quando é possível fazer um bem (ou evitar um mal) seria razoável afirmar que devemos fazê-lo, ao invés de não fazê-lo. Esse argumento, essencialmente de tipo deontológico, corresponde à ética médica tradicional, embasada nos princípios hipocráticos da não maleficência e da beneficência, e pode ser formulado também de outra forma: "somos moralmente responsáveis tanto pelo mal que fazemos quanto pelo mal que poderíamos ter evitado", visto que não há uma diferença moral substantiva entre causar dano e sofrimento, por um lado, e deixar que isso aconteça, por outro. Nesse caso, a única objeção relevante seria aquela segundo a qual só podemos ser benevolentes com alguém se o possível destinatário de nosso ato cognitiva e moralmente competente - aceitar que o sejamos, isto é, se respeitarmos sua autonomia para decidir o que é melhor para ele, e independentemente de ele estar "certo" ou "errado" (conforme nossos parâmetros). Em outros termos, tal tipo de argumento entra, muitas vezes, em conflito com o princípio do respeito da autonomia pessoal, o que não pode ser menosprezado, pois foi graças a esse princípio que se tornou possível criticar, nas últimas décadas, o paternalismo médico.

4) $\mathrm{O}$ argumento da autonomia pessoal, segundo o qual a livre vontade individual é condição necessária e suficiente para utilizar qualquer tipo de terapia gênica (tanto a somática quanto a germinal), desde que isso não crie um dano real para terceiros. Entretanto, nesse caso, podem surgir conflitos entre o princípio do respeito à autonomia pessoal e o princípio da justiça, relativo, por exemplo, à alocação equitativa dos recursos disponíveis em determinada situação sanitária. Com efeito, e sem entrar aqui nos detalhes dessa discussão, é prima facie razoável afirmar a legitimidade moral de intervir na vida de alguém se isso corresponder a seus melhores interesses (embora muitas vezes em contraste com seus desejos) e se a intervenção for aceita por um destinatário (pelo menos 
razoável), pois tais interesses podem não ser satisfeitos; por exemplo, quando houver outros interesses mais fortes (como a proteção da saúde do maior número).

\section{Os argumentos contrários à intervenção sobre o genoma humano}

Os principais argumentos contrários à intervenção sobre o genoma humano são:

1) O argumento da ladeira escorregadia (slippery slope argument), segundo o qual deveríamos evitar fazer algo - mesmo que isso resultasse em um bem atual - para evitar eventuais danos ou abusos futuros. Aplicado à intervenção sobre o genoma humano, esse argumento implica que o risco de abusos seria razão suficiente para não fazê-la. Em regra, tal argumento é utilizado para prevenir o risco de políticas eugênicas de tipo discriminatório (como as já lembradas políticas eugenistas da biocracia nazista). Embora pertinente em casos-limite - nos quais esse tipo de risco é efetivamente preponderante -, o argumento é em regra pouco consistente, porque preconceituoso e porque pressupõe - como alternativa e de forma irrealista e simplista - uma sociedade de risco zero, quando sabemos que as sociedades complexas são de fato sociedades do risco estrutural. Ademais, se o aceitássemos sem mais, não teríamos, por exemplo, a maioria das substâncias e dos procedimentos que permitiram melhorar, de forma significativa, nosso bem-estar humano, e correríamos o risco real de não nos prevenirmos contra riscos futuros.

2) O argumento teleológico, segundo o qual a utilização da engenharia genética seria uma forma não natural e arrogante de interferir no finalismo intrínseco dos processos naturais, garantido por uma suposta sabedoria evolutiva (não necessariamente de origem divina). Esse argumento é uma versão forte do anterior e, muitas vezes, vem acompanhado de um argumento adicional - de tipo teológico segundo o qual a utilização da engenharia seria fazer o papel de Deus, o que interferiria, de forma indevida, nos planos de uma pressuposta sabedoria divina norteadora. A principal fragilidade do argumento do respeito ao finalismo intrínseco está na desconsideração de que o humano é, na melhor das hipóteses, um ser natural sui generis, e isso 
desde que começou o processo de hominização: como ser na origem neoténico, ele precisa da cultura, inclusive da cultura tecnocientífica e biotecnocientífica, para satisfazer seus interesses e desejos, e pode, inclusive, precisar da engenharia genética para garantir a qualidade da sua vida e a daquela das gerações futuras.

3) O argumento do direito a um genoma não modificado, como condição para a preservação dos direitos humanos fundamentais, a começar pelo direito à autonomia pessoal, que seria em princípio seriamente prejudicado pela modificação do genoma humano. Esse argumento é problemático porque pressupõe que a preservação da integridade do genoma seja condição necessária para a preservação da autonomia pessoal. Implica, portanto, que nós somos essencialmente nosso genoma, pois tudo o que nos diz respeito estaria, em última instância, determinado por nossos genes, o que é - pelo menos de acordo com o estágio atual do conhecimento - uma confusão patente entre identidade orgânica e identidade pessoal (que os avanços no campo das neurociências talvez possam ajudar a resolver).

4) Oargumento da equidade, segundo o qual, perante os problemas urgentes e prioritários da saúde pública, a intervenção no genoma constituiria um desvio ilegítimo de parte significativa dos parcos recursos disponíveis para privilegiar uma minoria. Esse argumento é complementar ao anterior e aparentemente procede, pois levanta, de forma pertinente, a bandeira da justiça distributiva dos bens existentes, inclusive aqueles propiciados pela vigência do paradigma biotecnocientífico. Entretanto, não considera a possibilidade de tal intervenção se tornar uma necessidade para o bem-estar do maior número de pessoas, e até para a sobrevivência da própria espécie humana em condições ambientais adversas, caso em que a intervenção no genoma seria prima facie justificada.

\section{Considerações críticas sobre os dois tipos de argumento}

Tais são, evidentemente, apenas alguns argumentos pró e contra a intervenção biotecnocientífica sobre o genoma humano. Porém, o que se pode dizer ao analisar as argumentações aqui apresentadas é que, em regra, é mais fácil 
encontrar as falhas dos argumentos contrários ao uso desses novos produtos e procedimentos do que propor uma teoria consistente e propositiva em favor da engenharia genética, quando ela implique a transformação da chamada natureza humana. As razões são, provavelmente, muitas. Além da já citada relativa novidade do paradigma biotecnocientífico, o qual inevitavelmente leva a uma série de medos, justificados ou não, é possível que a moralidade do mundo contemporâneo esteja em um momento de transição paradigmática que indicaria uma transformação antropológica em curso, a qual implicaria também a possível emergência de uma nova moral, embora - seguindo certo consenso atual entre especialistas em ética e bioética - o mais provável seja uma consolidação do pluralismo moral atual, faute de mieux.

Ou seja, o que, provavelmente, está em jogo, por trás das críticas à engenharia genética, é o contraste entre dois tipos de moral: a moral tradicional, norteada essencialmente pelos argumentos da naturalidade e da identidade entre os desígnios divinos e a teleologia dos processos naturais, e baseada substancialmente em deveres absolutos e na interdição de transgredir uma suposta ordem constituída, segundo a qual haveria conhecimentos em princípio proibidos; e outra moral em formação, cujos princípios são reconhecidamente históricos e contextuais, e cujos deveres só podem ser considerados válidos prima facie, segundo as contingências históricas e a configuração do imaginário social de acordo com tais contingências.

De fato, a moral tradicional está baseada numa dupla interdição: a) aquela segundo a qual a vida humana é da ordem do sagrado, não podendo, portanto, ser violada (não entraremos aqui no mérito da polissemia do termo sagrado, que abordamos no terceiro ensaio com base nas reflexões de Agamben), a não ser por algum desígnio divino, que pontualmente os representantes de deus na Terra poderiam eventualmente interpretar; b) aquela segundo a qual os supostos desígnios divinos coincidiriam com a ordem natural e, portanto, transgredir as leis naturais implicaria transgredir a ordem divina e vice-versa.

Já a moral contemporânea (cujas raízes se situam no humanismo da Renascença e do Iluminismo) é em princípio racional e secular, e sua legitimidade não se situa (prevalentemente) nem na lei divina nem nas leis naturais, mas, substancialmente, na racionalidade dos argumentos que a defendem e na eventual negociação entre sujeitos e comunidades morais, mesmo que 
isso implique - em determinadas circunstâncias - a transgressão das leis ditas naturais.

Ademais, não podemos esquecer que a transgressão das leis naturais é um fenômeno típico da cultura humana, produto - como já vimos - do processo de hominização. Ela se dá desde pelo menos a transgressão das leis da gravidade pela aviação até a transgressão da medicina - pelo menos desde que esta soube reverter os decursos normais das doenças pela administração de antibióticos, pelas cirurgias e, atualmente, pela genômica. Em outros termos, a cultura é sempre, de alguma forma, uma antinatureza ou um processo transgressivo. Com efeito, foi uma série de transgressões que permitiu melhorar sensivelmente a qualidade de vida de muita gente, como no caso daqueles indivíduos não privilegiados pela "mãe natureza", porque mais sujeitos (ou suscetíveis) a doenças e moléstias. Por que, então, deveríamos confiar mais nas leis naturais e nos acasos de doença e saúde, e menos na competência humana para transpor os limites naturais de nossa condição humana? Em realidade, o ser humano introduz no seu mundo vivido um ethos formado por valores como a justiça sanitária, o respeito à autonomia individual, os princípios da não maleficência, da beneficência, da responsabilidade individual e coletiva, dentre outros, e os considera como patrimônio comum possível da humanidade. Como de fato aconteceu com a criação, após a Segunda Guerra Mundial, da Declaração Universal dos Direitos Humanos (1948). Por que, então, não considerar válidos tais princípios e valores, independentemente do fato de sua aplicação respeitar ou não os supostos desígnios divinos - sobre cuja interpretação já houve guerras de religiões, fogueiras e tantos outros abusos contra aqueles valores hoje chamados de direitos humanos fundamentais - ou as leis naturais - que, como nos ensina a história da ciência, são, muitas vezes, novamente interpretadas? Essas são algumas questões que merecem reflexão, antes de se levantar os escudos contra as supostas transgressões malignas perpetradas pela engenharia genética.

Evidentemente, os deslizes são sempre possíveis, sobretudo os de cunho autoritário, como salientam as declarações internacionais, uma vez que a engenharia genética pode se tornar um meio para políticas eugênicas ou imunitárias discriminatórias voltadas para indivíduos e populações considerados mal adaptados ou até inferiores, além de ferir o princípio de 
respeito à autonomia das gerações futuras (destacado por Habermas), visto que estaríamos decidindo em seu lugar o que deveria ser melhor para elas e, sobretudo, sem seu consentimento - evidentemente impossível de ser obtido. Mas esse tipo de crítica tem a ver com a terapia genética da linha germinal porque esta pode manipular o genoma dos futuros seres, dispondo, assim, sobre o que provavelmente será sua identidade e suas reais possibilidades de escolha.

Entretanto, esse tipo de crítica merece dois comentários. Em primeiro lugar, deve-se considerar que nós não somos (apenas) os nossos genes (como tampouco somos apenas nosso corpo biológico), mas somos, também (ou sobretudo), o produto de nossa história pessoal, familiar e social, de nossa cultura, de nossas experiências feitas com nossos corpos e nossos espíritos. Em outros termos, somos nossas biografias. Em segundo lugar, sofremos também os efeitos (positivos e negativos) de nossa educação, dos hábitos e dos valores morais apreendidos em nossas culturas e épocas respectivas, o que não nos impediu de avaliar criticamente tal herança cultural e de, muitas vezes, optar por outros valores e hábitos, diferentes e considerados, por alguma boa razão, melhores. Se isso faz sentido, por que então a transformação e determinação do patrimônio genético seria uma forma pior de violar nossa autonomia pessoal do que a educação ou qualquer outra forma de intervenção médica ou sanitária? Ademais, se é verdade que em ciência nunca se deveria dizer aprioristicamente nunca - pois corremos o risco de sermos refutados posteriormente pelos fatos - e supondo que as gerações futuras decidam baseadas nos dados atualizados do Projeto Genoma Humano - que é melhor recuperar alguma característica do passado, revertendo, portanto, as transformações adquiridas, quem e o que as impediria? Uma impossibilidade real? A incompetência humana? O acaso?

As questões aqui delineadas são, evidentemente, complexas e delicadas, e a maioria dos argumentos morais pró e contra pertence à grande zona cinzenta do saber e da moralidade (ou ethos) encarada pela ética aplicada e pela bioética, pois os fatos aos quais se referem se inscrevem em um ambiente de incertezas, tanto cognitivas como operacionais. Por isso, essa zona cinzenta é um lugar de conflitos e dilemas morais atuantes, que demandam análises muitas vezes longas e difíceis, e cujas soluções podem ser, na maioria das 
vezes, contraintuitivas, obrigando-nos a rever constantemente, e com espírito crítico, nossos paradigmas e sistemas de valores. Aliás, se os problemas não fossem complexos, provavelmente não precisaríamos de uma nova disciplina como a bioética, pois a ética tradicional e o respeito à sabedoria do passado provavelmente seriam suficientes.

Entretanto, mesmo complexos (ou provavelmente por isso mesmo), os problemas devem ser enfrentados, para evitar fundamentalismos (tanto religiosos como laicistas) que, quase sempre, prejudicam o bem-estar da maioria da população, pois implicam, muitas vezes, princípios que mal se integram à moralidade efetiva das sociedades democráticas e pluralistas.

Mas, para garantir (ou tentar garantir) uma abordagem que possa ser considerada pelo menos razoável da conflituosidade implicada pela genômica, precisamos de uma análise paciente dos argumentos em jogo, que seja a mais racional e imparcial possível, e, também, respeitosa para com as crenças pessoais e as comunidades morais específicas afetadas, desde que estas não prejudiquem concretamente o interesse coletivo (como no caso de fanatismos e fundamentalismos). Portanto, parece razoável e moralmente justificável afirmar que devemos tolerar alguma forma de constrangimento, pois somente assim podemos conviver num mundo em que os interesses e valores legítimos são muitos e, quase sempre, em conflito entre si, nos obrigando a construir os indispensáveis pontos de convergência, necessários para uma convivência pelo menos tolerante e civilizada.

A principal consequência disso tudo é que, provavelmente, não é mais possível, atualmente, uma moral geral comum, isto é, uma moral forte ou abrangente, capaz de gerar consenso de todos sobre os sistemas de valores a serem adotados. O que é possível é apenas uma moral (que pode eventualmente ser vista como uma colcha de retalhos) resultante de desacordos entre pessoas razoáveis que procurem alguma forma de convergência entre atores sociais distintos, com interesses em conflito, mas capazes de convergir sobre alguns bens primários que devem ser equitativamente compartilhados.

No caso específico da engenharia genética não existe consenso, nem uma teoria moral que a justifique em qualquer circunstância. Entretanto, podese dizer também que os argumentos contrários resultam, na maioria das 
vezes, mais de medos injustificados (ou pelo menos exagerados) e de reações prevalentemente emocionais do que de perigos reais, sobretudo se encararmos a intervenção sobre o genoma humano do ponto de vista sanitário e de acordo com a postura de uma ética laica e pluralista.

A bioética em genômica parece, portanto, sugerir não tanto a atitude de ser a priori contra ou a favor da intervenção sobre o genoma humano (ou de outras espécies), mas sim um acompanhamento de tais intervenções pela sociedade civil informada e capacitada (ou empoderada), a começar pelo acompanhamento das pesquisas em genômica. Como já acontece, inclusive no Brasil, com a pesquisa envolvendo seres humanos, avaliada pelos comitês de ética em pesquisa, como no sistema brasileiro Comitês de Ética em Pesquisa/ Comissão Nacional de Ética em Pesquisa (CEP/Conep).

Trata-se de tarefa certamente difícil quando se consideram não só os grandes princípios éticos, mas também e, sobretudo, os riscos de o paradigma biotecnocientífico não ser acompanhado de perto pelo paradigma bioético. O papel deste paradigma não é apenas dar a entender a conflituosidade constitutiva de toda práxis humana; cabe-lhe também uma tarefa normativa, a qual visa em particular a proscrever comportamentos considerados fontes de danos e sofrimentos evitáveis e tentar, dessa maneira, construir convergências capazes de resolver os conflitos de interesses e valores que perpassam as práticas humanas que envolvem outros humanos e outros seres vivos não humanos, situados em seus ambientes.

\section{Os conflitos teóricos na própria ética}

Essa tarefa prática não é, entretanto, consensual dentro do próprio campo da ética. Este, como vimos, encontra-se dividido entre quem considera a ética como sinônimo de moral e quem separa a ética da moral, considerando a primeira a ciência da moral, a qual tem por objeto de estudo não tanto os comportamentos humanos (estudados por outras ciências humanas e sociais específicas, como psicologia, antropologia e sociologia), mas os juízos de valor, negativos e positivos, sobre tais comportamentos, por considerar que "os juízos de valor sobre a conduta são fatos reais" (Lalande, 1972a: 306). Ademais, para aqueles que separam claramente a ética da moral, a primeira deveria se ocupar também do problema da justificação dos enunciados morais pertencentes à 
moral. Algo parecido acontece entre aqueles que consideram a ética como discurso de segunda ordem sobre os discursos de primeira ordem referentes aos sistemas de valores e crenças acerca do bem/bom e do mal, do correto e incorreto, do justo e injusto, vigentes no espaço e no tempo, representados pela moral. De acordo com essa concepção da ética - conhecida também como metaética (e que abordamos especificamente no primeiro ensaio desta coletânea) -, a ética deveria analisar, da maneira mais racional e imparcial possível, apenas os conflitos morais - como se pretende metodologicamente de qualquer forma de saber suficientemente organizada e consistente que pretenda ter direito ao qualificativo "discurso de segunda ordem".

Essa segunda vertente não é desprezível historicamente. A distinção entre sistemas morais vigentes e outros sistemas representados pelas análises críticas dos primeiros, isto é, a separação entre discursos de primeira ordem (como a moral) e discursos de segunda ordem (como a ética), permitiu vislumbrar (embora com muitas dificuldades teóricas e práticas, como também vimos no primeiro ensaio desta coletânea) a possibilidade de que um ponto de vista universal ou objetivo relativo aos sistemas de primeira ordem referidos aos valores morais vigentes venha a dirimir conflitos não dirimidos por outros meios (por exemplo, pelo direito).

Formalmente, a necessidade de ocupar o lugar de um discurso de segunda ordem em ética foi fortemente defendida - e com bastante sucesso pelo menos em âmbito anglo-saxônico - durante quase um século pela ética analítica. Esta, iniciada com a obra de Henry Sidwick The Methods of Ethics, de 1874, só encontra críticos de peso quando, entre o fim da Segunda Guerra Mundial e o surgimento dos vários movimentos de contestação e reforma da ordem vigente nos anos 60 do século XX, se dão as condições para que surjam também as éticas aplicadas. Depois que se soube abertamente das práticas humanas contra outros humanos verificadas na Armênia, em Auschwitz, Hiroshima, Nagasaki e tantos outros abusos e extermínios cometidos em situações de guerra (mas também em situações de paz aparente), a ética precisou de um upgrade radical para poder se renovar e não ser simplesmente reduzida às análises de segunda ordem.

É nesse processo de complexificação das relações entre vida teórica e vida prática, mas também entre discursos e metadiscursos (ou discursos de segunda 
ordem), que surge, já nos anos 70 do século XX, aquela que poderíamos chamar de ética analítica dos casos concretos, que nada mais seria que uma aplicação das ferramentas conceituais e metodológicas (desenvolvidas com rigor e sucesso durante os quase cem anos de duro labor analítico) aos novos conflitos e dilemas morais surgidos da acrescida competência (e potência e poder) do humano para direcionar seu destino.

Entretanto, aqui também fica uma questão em aberto: a de saber o que possam legitimamente fazer as ferramentas da ética e da bioética para controlar as pesquisas e evitar sua eventual iatrogenia, pois - de acordo com uma boutade bastante lembrada e atribuída a Albert Einstein - fazer pesquisa é algo demasiado importante para que as decisões sejam deixadas nas mãos apenas dos próprios cientistas, que podem, por exemplo, estar envolvidos em conflitos de interesses ou em fraudes, como qualquer cidadão comum. Nesse sentido, vale a pena lembrar o caso da conflituosidade inerente às práticas da indústria farmacêutica, denunciada, por exemplo, pela antiga editora-chefe do New England Journal of Medicine, Marcia Angell, para quem tal indústria "afastou-se enormemente do seu nobre propósito original de descobrir e produzir novos medicamentos úteis" para tornar-se "uma máquina de marketing para vender medicamentos de benefício duvidoso [que] usa sua fortuna e seu poder para cooptar cada instituição que possa se interpor em seu caminho" (Angell, 2007: 16).

Em razão dos enormes interesses em jogo, seria atualmente demasiado arriscado que os profissionais continuassem conspirando - consciente ou inconscientemente - contra os leigos (como já afirmara no século XVIII o escritor inglês Jonathan Swift), e a prova do caráter altamente problemático da pesquisa que envolve seres humanos seriam os inúmeros abusos cometidos, ao longo do século XX, por especialistas do campo que hoje chamamos de ciências da vida e da saúde contra os direitos humanos, em regimes tanto ditatoriais como democráticos, amplamente relatados desde os anos 1960, inclusive pela emergente bioética. 


\section{O que Fazer, Então?}

Quais são, em definitivo, os principais problemas éticos levantados pela genômica na vigência do paradigma biotecnocientífico em um mundo cada vez mais globalizado?

Dentre os principais objetos de questionamentos éticos já feitos recentemente (eugenismo, monopólio da informação genética, patenteamento da vida, discriminação de portadores de características suscetíveis de adoecimento), os mais problemáticos, em uma sociedade democrática e pluralista, são provavelmente aqueles que dizem respeito às tentativas de monopólio, via patenteamento, das informações que de direito pertencem a cada um e a todos. Afinal, o genoma humano, contrariamente aos alfabetos, não é uma invenção stricto sensu, mas a descoberta de algo real, mesmo que simbolizado e codificado de acordo com uma linguagem determinada. O risco, nesse caso, é em primeiro lugar que o genoma humano se torne mera mercadoria - na feliz expressão dos bioeticistas Giovanni Berlinguer e Volnei Garrafa (1996) -, aumentando a probabilidade de aprofundamento da conflituosidade social e da injustiça. A redução desse grande invento que é o Projeto Genoma Humano à mera dimensão mercadológica e excludente parece contradizer a própria tradição da ética científica, que, apesar de algumas manchas muito graves (como a "colaboração" de alguns cientistas em regimes totalitários), se enraíza, em princípio, no amor pelo conhecimento e na preocupação com a melhoria da condição humana.

Em uma sociedade democrática em que a cidadania seja efetivamente exercida e haja, portanto, algum empoderamento da sociedade civil e de todos os seus cidadãos, é importante considerar a percepção social sobre os fatos tecnocientíficos e biotecnocientíficos. Mas, como vimos, o campo das percepções sociais das práticas da biotecnociência está dividido, grosso modo, entre dois extremos: por um lado, os tecnofílicos, para os quais qualquer nova tecnologia e biotecnologia serão bem-vindas, sem que se preocupem com seus eventuais efeitos adversos presentes ou futuros; por outro, os tecnofóbicos, para quem a biotecnociência estaria desenvolvendo poderes capazes de transformar o mundo e o próprio homem indevidamente, prejudicando, inclusive, os melhores interesses das gerações futuras (que são de fato inferidos, sem mais, a partir dos atuais). 
Entre os dois extremos, entretanto, há um meio-campo em construção e bastante complexo, no qual podemos identificar pelo menos três posições distintas.

1) A primeira é aquela dos adeptos do princípio de precaução, princípio moral próximo do antigo princípio de não maleficência, mas situado em condições de incerteza, e que defende a obrigação de se abster de uma ação quando esta pode ter consequências danosas para os envolvidos. De fato, o princípio de precaução é um princípio sui generis - em parte herdeiro da antiga prudência aristotélica, ou phronesis - e de pouca utilidade prática em situações problemáticas complexas, pois não se baseia em probabilidades de ocorrência de danos claramente identificáveis; não especifica a natureza de tais danos e, sobretudo - de acordo com um argumento consequencialista -, se o adotássemos nunca teríamos a certeza de que os fatos da biotecnociência terão consequências positivas ou não, se são úteis ou não, e em caso positivo, em que condições e para quem. Por isso, seus defensores devem responder às críticas que consideram o princípio precautório como, muitas vezes, um empecilho ao desenvolvimento e às mudanças consideradas necessárias para a própria sobrevivência da espécie humana em um mundo em rápida transformação. Segundo tais críticas, a aplicação de tal princípio pode implicar a inação, a qual tem também suas consequências e demanda assumir responsabilidades pela privação dos eventuais benefícios que a biotecnociência poderia trazer para a condição humana (Balistreri, 2002).

2) A segunda posição se baseia no princípio de responsabilidade, de acordo com a proposta inicial de Hans Jonas, referida à ética de responsabilidade de Max Weber, que a distinguia da ética da conviç̧ão, como relatado pelo próprio Jonas em uma conferência de 1986, feita contra um niilismo supostamente reinante nas sociedades modernas, democráticas e individualistas (Jonas, 1987). A ética da responsabilidade - decorrente desse princípio - preocupa-se corretamente não só com o presente, mas também com o futuro da espécie humana e com o impacto das ações humanas sobre os processos naturais e sociais, considerados cada vez mais ameaçados e ameaçadores, partindo do pressuposto de que 
os processos naturais seriam orientados por um finalismo intrínseco a ser em princípio respeitado. Por isso, a ética da responsabilidade implicaria uma política de homens prudentes, preocupados em proteger a existência humana a longo prazo e sabendo que a sobrevivência do ser humano dependeria da preservação dos processos naturais como são, e não da transformação da natureza e da natureza humana naquilo que queremos que sejam. Entretanto, e apesar do mérito de ter destacado a responsabilidade para com as gerações futuras, um dos problemas da ética jonasiana é sua concepção da evolução, que desconsidera a contingência e o acaso dos processos naturais, substituídos pelo finalismo intrínseco a ser absolutamente respeitado e que interditaria ao humano intervir em sua própria evolução.

3) A terceira posição considera que a biotecnociência pode ser em princípio benéfica para os humanos presentes e futuros, no sentido de constituir um meio a serviço dos ideais morais e políticos de justiça, igualdade e emancipação. Formulada por Karl-Otto Apel e Jürgen Habermas, é conhecida como ética procedimental da discussão, constituída por uma argumentação sem restrições entre todos os envolvidos em uma controvérsia moral, com todos compartilhando o objetivo de um consenso racional, adotado livremente por todos os envolvidos em uma disputa e que seja capaz de evitar tanto medidas autoritárias do estado de exceção - desrespeitoso dos direitos humanos (Apel, 1987) - quanto o "eugenismo liberal" (Habermas, 2001). Embora seja uma tentativa de evitar as dificuldades tanto da ética da precaução como da ética da responsabilidade, essa posição pode também ser criticada devido, essencialmente, a seu idealismo (compartilhado em parte também pela ética da responsabilidade): ela pressupõe que a única forma de emancipação humana seja de tipo simbólico (ou comunicativo), e não também técnica e prática - ou seja, por pressupor que "não existe evolução humana; só existe a história humana, que é fundamentalmente simbólico-espiritual, e não tecnomaterial" (Hottois, 2005: 112, destaques do original). A segunda característica criticável seria seu conservadorismo naturalista e, consequentemente, sua "concepção demasiadamente negativa da técnica", incapaz de ver 
"que as intervenções biológicas poderiam contribuir para tornar os seres humanos menos desiguais no nascimento e mais capazes de superar as alienações", graças, inclusive, ao "impulso das biotecnologias e da biomedicina", em vez de ver apenas "os aspectos destruidores e liberticidas do progresso tecnocientífico" e desprezar "totalmente a extraordinária criatividade deste progresso, que não cessa de enriquecer o real (...) [e] as imensas capacidades de conservação, preservação, de guardar na memória e mesmo de 'ressurreição' que as tecnociências não param de desenvolver" (Hottois, 2005: 122-126).

Resumindo, a ética procedimental da discussão seria criticável porque por um lado reconheceria o poder do simbólico, mas por outro desconheceria as potencialidades emancipatórias da biotecnociência e a possibilidade que esta teria de enriquecer a própria natureza humana, em vez de considerá-la como bode expiatório "de todas as disfunções, injustiças, carências de nossa civilização multicultural e tecnocientífica em vias caóticas de globalização". Tal desconhecimento teria consequências moralmente importantes, pois, como argumenta ainda Hottois, "[a] tecnocientofobia associada ao conservadorismo naturalista tornou-se um verdadeiro obstáculo epistemológico, impedindo que se identifiquem e incriminem as verdadeiras áreas responsáveis", que são as "hierarquias políticas, econômicas e financeiras", e se a biotecnociência pode ser mal utilizada, isso se deve, muito mais, "ao que se continua a chamar 'a natureza humana', à falta de consciência e de grandeza de coração e de espírito, à finitude e à malignidade dos seres humanos" (Hottois, 2005: 129-130).

É nesse contexto discursivo e argumentativo que se situa a moralidade da genômica, abordada pela bioética e cuja problemática tentamos aqui delinear. 


\section{Bioética 'e/ou' Biossegurança: uma possível interface na avaliação e gestão da prática da biotecnociência?*}

Bioética e biossegurança podem ser vistas - em um sentido muito geral e abrangente - como caixas de ferramentas teóricas e práticas, consideradas pertinentes e legítimas para estudar, avaliar, normatizar e controlar as ações, os produtos e os dispositivos resultantes da competência biotecnocientífica aplicada para transformar seres e sistemas vivos. E isso devido, sobretudo, a uma periculosidade real (referida a danos) ou potencial (referente a riscos) que pode afetar, de forma significativa, a qualidade de vida, presente e futura, de indivíduos e populações humanas. E também de animais não humanos e dos próprios ambientes naturais.

Portanto, nesse sentido muito geral, as duas caixas de ferramentas podem ser vistas como dispositivos que têm uma função normativa e de controle sobre todas as ações humanas que se dão no mundo vital (ou mundo-davida: Lebenswelt) (Husserl, 1976), do qual a cultura e a ciência emergiram, transformando-o. Tal transformação foi possível graças, em particular, à aliança estabelecida, ao longo da história da humanidade, entre a capacidade poiética (ou técnica) do Homo faber e a competência logoteórica (ou simbólica) do Homo sapiens, para entender e transformar o mundo, inclusive o mundo

* Revisão e aprofundamento de SCHRAMM, F. R. Bioética e biossegurança. In: COSTA, S. I. F.; OSELKA, G. \& GARRAFA, V. (Orgs.). Iniciação à Bioética. Brasília: Conselho Federal de Medicina, 1998. 
da vida, por meio da biotecnociência. Bioética e biossegurança podem ser utilizadas para abordar os danos e os riscos para a saúde e o bem-estar, resultantes do saber-fazer tecnocientífico, inicialmente concebido como instrumento ou meio para entender e controlar os fenômenos naturais - inclusive seus ris$\cos$-, mas que, paradoxalmente, teria participado da transformação das sociedades em uma única sociedade global de riscos. Nesta sociedade, qualquer atividade humana parece ter se tornado uma fonte de ameaças não elimináveis, pelo menos se pensarmos em catástrofes como aquelas de Seveso (1976), Bhopal (1984) e Chernobyl (1986) (Beck, 1986) e a mais recente de Fukushima (2012), que parecem ter reintroduzido no imaginário social "uma forma de fatalidade que as Luzes haviam afastado", em vez de formas de "equilíbrio entre riscos e proteção, liberdade e segurança, sensibilidade e conforto" (Kermisch, 2007a: 7).

Assim, parece legítimo tentar estabelecer alguma interface entre esses dois tipos de saber (ou disciplinas ou dispositivos), visto que, diante do risco estrutural e global, bioética e biossegurança parecem compartilhar não somente alguma forma de controle (que não é uma das prioridades da bioética), mas também, e sobretudo, a preocupação normativa. Embora não necessariamente da mesma forma, pode-se dizer também que os dois tipos de saber parecem se ocupar do mesmo tipo de assunto: a avaliação tecnológica, a percepção dos danos e riscos envolvidos, comparados com os benefícios; ou seja, preocupam-se com a ponderação entre probabilidade de riscos e benefícios esperados.

Entretanto, apesar dessa proximidade, bioética e biossegurança constituem também âmbitos disciplinares e formas de saber distintos, que não podem, portanto, ser confundidos. Com efeito, a bioética pode ser considerada como um novo âmbito da ética, que se ocupa inter alia da moralidade dos atos biotecnocientíficos (que abordamos no segundo ensaio). A biossegurança, por sua vez, se ocupa dos riscos biológicos envolvidos no uso das biotecnologias no ambiente de trabalho e na sociedade em geral, lançando mão de medidas técnicas, administrativas e legais voltadas para a prevenção do adoecimento e a promoção da saúde humana, podendo ser definida como, essencialmente, uma forma de gestão dos biorriscos ou uma ferramenta para tomar decisões diante dos biorriscos. Ou seja, trata-se de um novo âmbito da "segurança para a saúde humana e para o meio ambiente", que inclui "a proteção da biodiversi- 
dade, quando forem utilizados organismos ou microrganismos geneticamente modificados", e os casos de "utilização confinada de organismos patógenos", preocupando-se também com a "ruptura dos equilíbrios naturais, ligados a nossos hábitos, às mudanças climáticas ou ao desmatamento [que têm] provavelmente facilitado o surgimento de vírus patógenos, mortais para o homem" (Moens, 2001a: 141).

\section{O Sentido das Palavras Bioética e Biossegurança}

O termo bioética, muitas vezes entendido como uma genérica ética da vida, é, em realidade, resultante da associação entre as duas palavras gregas bíos e ethos, e tal associação passa ao largo do fato de o que o termo vida, derivado do latim vita, reúne em uma única palavra os sentidos das palavras gregas, bíos e zoé - referidas respectivamente à vida prática humana (bíos), que implica a vida moral, a vida política e se aplica à polis, e à vida orgânica (zoé), que compartilhamos com os outros seres vivos. Por isso, a concepção segundo a qual a bioética é uma genérica ética da vida deverá enfrentar o problema de estabelecer se fazem parte de suas preocupações legítimas todos os aspectos da vida, ou apenas alguns deles, e de estabelecer, igualmente, como contribuir para eventualmente protegê-la e preservá-la: zoé, bíos, ou ambas.

Mas a concepção da bioética como uma genérica ética da vida tem uma variante, caracterizada por forte conotação ecológica e holística, como aquela defendida, por exemplo, por Leonardo Boff. Para esse filósofo e teólogo, as questões da ecologia, da ética e da espiritualidade estariam de fato interligadas, pois "refletem a crise de civilização pela qual estamos passando [e] visam oferecer elementos para um novo paradigma civilizatório que está emergindo e que pode dar sentido à nova fase da humanidade, a fase planetária", e têm como fio condutor a "esperança de que não vamos de encontro a um desastre, mas [rumo a] um novo renascimento [e à] irrupção de uma ordem mais alta e integradora" (Boff, 2009: 7).

Alternativas para a definição da bioética são aquelas que a entendem como uma ética da saúde, distinta da deontologia médica (por ser mais abrangente), vinculada ao direito à saúde e ao "fato de que a saúde e a doença são um campo universal de experiência, de reflexão e também de escolhas morais para 
todos" (Berlinguer, 1994: 14). Ou como uma ética da ciência, entendida como "observadora atenta dos avanços biotecnocientíficos" (Kottow, 2009: 11-12), mas caracterizada também "por uma forte interacção comunicacional" (Hottois, 2003b: 110).

Feito esse rápido mapeamento, pode-se dizer que o conceito de bioética não encerra um sentido unívoco, o que deixa em aberto a questão de seu estatuto ontológico (referente ao que a bioética é ou pretende ser) e epistemológico (referente ao conhecimento fidedigno e legítimo produzido). Entretanto, como observa Hottois, essa "relativa imprecisão não deve (...) tornar-se pretexto para rejeitar esta noção ou para a denunciar como uma criação artificial e ideológica", pois "[as] preocupações bioéticas são suficientemente partilhadas a nível universal, incluindo pelo mundo científico, para que se pretenda ver nelas apenas a expressão de um grupo social, seja ele qual for". Ou seja, "discursos e práticas bioéticas apresentam inegavelmente, apesar de sua grande diversidade, um 'ar de família' que basta para garantir a unidade semântica do emprego da palavra" (Hottois, 2003b: 111-112).

A biossegurança, por sua vez, pode ser vista como um novo tipo de saber que se ocupa dos artefatos da biotecnociência, para analisar e avaliar seus procedimentos e produtos do ponto de vista de sua segurança, entendida "tanto em sentido objetivo [quanto] em sentido subjetivo, [considerados ambos] necessários para uma política de segurança legítima e eficaz" (Schramm, 1998: 223).

A biossegurança aborda especificamente a questão dos riscos, também chamados biorriscos. Entendidos também como a probabilidade de sofrer danos de origem biológica (e biotecnológica), os biorriscos podem envolver prejuízos à saúde humana individual e coletiva, como no caso das infecções por agentes patógenos e das pandemias, mas também ao mundo animal e ao mundo vegetal, como nos casos do chamado mal da vaca louca ou do desaparecimento de espécies animais e da biodiversidade em geral. Trata-se, afinal, de "riscos de perturbação dos equilíbrios darwinianos entre todas as espécies microbianas, vegetais, animais, insetos e plantas, o clima e a qualidade dos solos e dos mares" (Moens, 2001b: 141).

A palavra biossegurança, que inclui em sua composição o termo bíos - de fato entendido, sobretudo, como zoé -, indica, em geral, uma "securitização 
dos fluxos vitais [que] compreende três dimensões: proteção, controle e regulação", e em particular "o conjunto dos dispositivos de proteção, controle e regulação do indivíduo considerado sob o aspecto de sua finitude biológica" e de sua "vulnerabilidade". Pode-se falar em "biossegurança protetora" diante da "mundialização [do] risco permanente", o que é também indicado pelo princípio de precaução entendido como "sinônimo de exigências de uma securitização absoluta das vidas frágeis frente ao conjunto dos riscos" (Gros, 2012: 174-179) e aplicado, por exemplo, pela Declaração do Rio de 1992 em seu projeto de proteger o planeta como um todo.

Entretanto, os debates sucessivos sobre a possibilidade/probabilidade de catástrofes irreversíveis nos ecossistemas e o consequente relativo silêncio da ciência - incapaz de passar das probabilidades para alguma forma de certeza científica e de estabelecer relações causais entre atividade humana e catástrofes ecológicas - fizeram com que, de acordo com o princípio de precaução, se instalasse um debate público norteado pela ideia de que "a simples possibilidade de um risco deve implicar medidas de precaução", alimentando, portanto, "o fantasma de uma segurança máxima, a reivindicação de um direito a ser protegido contra todos os riscos" (Gros, 2012: 179-180).

Feitas essas distinções conceituais iniciais, devemos ainda lembrar que muitas das questões abordadas pela biossegurança fazem parte também da pauta da ética aplicada conhecida como ética ambiental (ou ecoética). Esta, entendida, de acordo com Kristin Shrader-Frechette (2003: 188), como "campo de estudos filosóficos" que começa nos anos 1970, é "parcialmente o resultado do movimento ambientalista" e remete "às descobertas tecnológicas do século vinte, tais como o poder nuclear e os pesticidas químicos; seu uso excessivo e abusivo; e a identificação da degradação ambiental que tais tecnologias têm causado". Para essa autora, cujas pesquisas abordam "a irracionalidade dos cidadãos frente à 'racionalidade' das análises dos riscos, a falibilidade [tanto] dos especialistas [como] dos cidadãos, [e] a distinção entre riscos percebidos e 'riscos reais'" (Kermisch, 2007b: 228), um dos desdobramentos da emergência da ética ambiental seria a necessária integração da sociedade civil na gestão dos riscos tecnológicos e sociais, o que tornaria tal gestão em princípio mais democrática. Como justificativa, Shrader-Frechette apresenta quatro tipos de razão: 
1) uma razão a que a autora chama de lógica, pois a margem de incerteza científica nas análises dos riscos implicaria uma intervenção de juízos de valor;

2) uma razão propriamente ética, resultante do fato de a gestão dos riscos implicar consequências sobre o bem-estar da população, a qual teria, portanto, o direito de pelo menos manifestar sua opinião;

3) uma razão ontológica, pois haveria um tipo de risco que pode afetar valores democráticos fundamentais como a autonomia, o consentimento livre e esclarecido e a igualdade, o que faz com que a gestão dos riscos não possa ser deixada exclusivamente nas mãos dos assim chamados especialistas em riscos;

4) uma razão não denominada especificamente pela autora, mas que poderíamos chamar de tecnocientífica, pois resulta do fato de a análise dos riscos fazer parte do campo das tecnociências, entendidas como ciências aplicadas que utilizam técnicas, sendo que o fato de tal análise afetar a população como um todo implica que seus objetivos devem ser democraticamente determinados (Shrader-Frechette, 1995).

Entretanto, a análise científica dos riscos se dá sempre em um contexto marcado pela incerteza, o que torna uma possível definição padrão de risco não universalizável e, portanto, sempre questionável, pois a população não cometeria necessariamente mais erros que os especialistas quando se trata de interpretar dados probabilísticos, razão pela qual os riscos e as percepções de riscos deveriam ser considerados como de fato inseparáveis (Shrader-Frechette, 1990). Mas isso implica também "adaptar nosso saber, reconhecendo que a ciência está condenada a fornecer teorias que incluem juízos de valor tais como o poder preditivo ou a faculdade de explicação", pois "os especialistas não dispõem de nenhuma teoria objetiva, que seja aceita pelo conjunto da comunidade, e que lhe permitiria impor seus juízos sem discussão" (Kermisch, 2007b: 230). Ademais, implica considerar também fatores complementares no cômputo final, tais como "a equidade, o consentimento livre e esclarecido, os benefícios obtidos, assumindo o risco em questão" (Kermisch, 2007b: 229).

Assim, poder-se-ia dizer que existe não tanto uma identidade de competências e abordagens entre bioética e biossegurança, mas um compartilhar 
do mesmo tipo de preocupações a partir de olhares distintos e diferentes. Essa seria uma razão suficiente para tentar estabelecer uma interface entre tais ferramentas distintas. Tal interface seria representada por um dispositivo que permitiria aos dois tipos de saber se encontrarem e comunicarem para resolver conflitos tais como os conflitos de interesses - por exemplo, entre produtores e consumidores de produtos biotecnológicos - ou de valores - por exemplo, entre aqueles que remetem à sacralidade da vida ou à qualidade de vida, isto é, entre uma concepção que "indica a inviolabilidade ou intangibilidade da vida humana" e outra que "afirma como valor fundamental a qualidade da vida humana entendida como bem-estar e/ou como respeito da autonomia das pessoas" (Mori, 2002: 17), ou, mais simplesmente, para evitar danos ou controlar riscos considerados desnecessários e, portanto, em princípio evitáveis.

Se prima facie é correto dizer que uma interface é um dispositivo que pode permitir a comunicação empática entre tipos de saber diferentes e entre agentes de práticas distintas, surge a questão de saber o que distingue e vincula concretamente bioética e biossegurança, pois somente assim poder-se-ia falar, com propriedade, em interface e, portanto, justificar seu uso. E isso se for verdade que uma interface é aquele ponto, linha, superfície ou área que separa dois (ou mais) saberes distintos - isto é, que estabelece um limite comum a tais saberes - e permite o contato entre dois (ou mais) objetos ou campos de estudo, mas mantendo também a identidade dos diferentes objetos ou campos - isto é, sua autonomia disciplinar, pois esta é uma condição necessária para que se possa estabelecer uma eventual cooperação interdisciplinar de saberes considerados diferentes.

De um ponto de vista metodológico, essa interdisciplinaridade é algo bem diferente da mera multi e pluridisciplinaridade, que não implicam, necessariamente, um diálogo entre disciplinas: há autores que as diferenciam sem relacioná-las, considerando a multidisciplinaridade como um método que se refere a um "conjunto de disciplinas a serem trabalhadas simultaneamente, sem fazer aparecer as relações que possam existir entre elas", e a pluridisciplinaridade como mera justaposição de diversas disciplinas "situadas geralmente ao mesmo nível hierárquico e agrupadas de modo a fazer aparecer as relações existentes entre elas" (Menezes \& Santos, 2002). 
Tais distinções são importantes porque, sem essa preocupação com a precisão conceitual e a identidade específica de cada forma de saber - consideradas necessárias para sabermos o que distingue e, ao mesmo tempo, vincula saberes como a bioética e a biossegurança -, não poderíamos pensar corretamente essa possível interface e justificá-la.

A seguir, analisaremos detalhadamente essa noção de interface de bioética e biossegurança e tentaremos verificar se ela se justifica ou não; e em caso afirmativo, por que razão. Tal verificação será feita em dois momentos. No primeiro, relacionando essa interface com a evolução e a extensão do campo da bioética na época da vigência daquilo que chamamos de paradigma biotecnocientífico, entendido como

padrão de competência em adaptar [a] "natureza" humana aos desejos e projetos humanos [para] aliviar o sofrimento, prevenir doenças, melhorar as condições de vida, programar a qualidade de vida dos descendentes, programar o fim da vida [e] superar os limites impostos pela dimensão orgânica à condição humana [graças à] reprogramação da própria natureza humana. [Trata-se] essencialmente [de uma] recusa dos limites impostos pela evolução biológica. (Schramm, 1996: 114-115, destaque do original) ${ }^{7}$

No segundo momento, indagando:

1) por que a biossegurança precisaria da legitimação valorativa de uma ferramenta como a bioética para justificar seus procedimentos de controle; e

2) por que a bioética encontraria nos procedimentos da biossegurança um terreno propício ao diálogo entre legitimidade e legalidade dos procedimentos e produtos da biotecnociência, considerando que tais produtos podem ser vistos como "motivo de fascínio e espanto" e por que "parece que nenhuma disciplina, sozinha, possa dar conta [da legitimidade] deles" (Schramm, 1998: 217, 219).

Essa análise em dois tempos será precedida de um rápido histórico da problemática que leva à necessidade de a sociedade contemporânea estabelecer

\footnotetext{
${ }^{7}$ Em uma versão mais sintética, a biotecnociência pode ser definida como "o conjunto de ferramentas teóricas, técnicas, industriais e institucionais que visam entender e transformar seres e processos vivos, de acordo com necessidades/desejos de saúde e, de maneira geral, visando a um genérico bem-estar de indivíduos e populações humanas” (Schramm, 2005: 21).
} 
uma interface entre bioética e biossegurança na análise e gestão dos riscos e suas implicações sociais e políticas, visto que "a linguagem do risco participa ativamente na construção do espírito preventivo-persecutório na saúde, mediante práticas biopolíticas que desembocam na construção do homem responsável por sua saúde", ou seja, considerando "as formas modernas de regulação moral mediante novas estratégias de culpabilização socialmente instituídas" (Castiel \& Diaz, 2007: 10).

\section{Uma Rápida Genealogia da Bioética e da Biossegurança}

Historicamente, a problemática explícita da biossegurança, entendida como dispositivo multidisciplinar de avaliação e gestão dos riscos, pode ser considerada mais antiga, pois o termo inglês biosafety surge depois da Segunda Guerra Mundial, embora a primeira ocorrência do termo bioética se deva a Fritz Jahr (1927), que usou Bio-ethik com o sentido amplo de respeito por qualquer ser vivo. Kantianamente, Jahr entendeu Bio-ethik como fim em si mesmo, de forma bastante diferente da consideração interdisciplinar do cancerologista Van Rensselaer Potter, que - embora se referisse também a um sentido amplo do termo - pretendia estabelecer uma ponte entre o saber científico e o saber moral, ou seja, definir "vínculos teóricos e metodológicos entre ciências da vida e humanidades tendo como objetivo prático [a] sobrevivência humana na ecosfera" (Schramm, 2011: 304, destaque do original).

O termo biosafety (do qual deriva nosso termo biossegurança) surge no âmbito do Center of Disease Control (CDC) de Atlanta, com a preocupação de detectar, avaliar e gerir os chamados biorriscos (biohazards), naquela época entendidos como "os perigos biológicos engendrados diretamente pela natureza ou pela atividade humana". Por perigos "diretamente engendrados pela natureza" entendiam-se aqueles resultantes de uma relação entre "o indivíduo ignorante ou sem defesas diante do organismo biológico perigoso", e por perigos engendrados "pela atividade humana" aqueles que constituem "a principal fonte de outros biorriscos [e] que resultam do impacto da atividade humana sobre o ambiente", o que teria como principal consequência tornar o homem "a maior fonte de perigos para o ambiente e, 
portanto, para si mesmo", podendo-se até dizer que "o principal biorrisco é hoje a humanidade" (Moens, 2001b: 141-142).

Na sociedade contemporânea, caracterizável como hipercomplexa e altamente conflituosa, o problema da gestão dos riscos requer a cooperação de uma multiplicidade de técnicas para tentar encontrar soluções, mas trata-se também de uma questão política ou biopolítica, por envolver a população. Uma vez que tal gestão implica atos, ela é ainda objeto de uma avaliação ética, como pode ser aquela produzida pela ética ambiental e a bioética. Portanto, a gestão dos riscos tem a ver "não somente com considerações normativas sobre o que deveria ser uma boa governança dos Estados e das instâncias internacionais em matéria de riscos objetivos", mas também com "uma reflexão crítica sobre o que liga a gestão dos riscos [e] a 'governamentalidade" (Caeymaex, 2007: 111).

O termo governamentalidade é introduzido por Michel Foucault para indicar 0

conjunto constituído pelas instituições, os procedimentos, análises e reflexões, os cálculos e as táticas que permitem exercer essa forma bem específica, embora muito complexa, de poder que tem como alvo principal a população, como forma maior de saber a economia política, como instrumento técnico essencial os dispositivos de segurança. (Foucault, 2004a: 111)

Seu objetivo é compatibilizar a liberdade dos agentes e a seguridade, vigiando para que "a mecânica dos interesses não provoque perigos tanto para os indivíduos como para a coletividade" (Foucault, 2004b: 67).

\section{A questão dos riscos}

A palavra risco é de origem incerta, mas alguns filólogos a fazem derivar do francês risque (século XVI), com o significado de "perigo, inconveniente mais ou menos previsível", por sua vez derivado do italiano medieval risco (ou rischio) (século XIII), e este do latim risicus (ou riscus), derivados de resecum (o que corta), substantivo derivado do verbo resecare, cortar (Bloch \& Von Wartburg, 1968: 556).

As primeiras ocorrências dessa palavra parecem ter surgido na esfera comercial e no direito marítimo, em que risco teria expressado o "perigo ligado 
a um empreendimento", assim como na esfera militar, em que teria indicado a "sorte ou má sorte de um soldado" (Houaiss \& Villar, 2001: 2.462). O termo esteve, às vezes, associado à palavra fortuna, que tinha o significado de "destino ou sorte", considerada independente da vontade humana, o que era indicado pela identificação com a antiga deusa de mesmo nome (Fortuna), entendida como força superior e imanente que dominava as ações humanas e tida como "distribuidora de felicidade e dor ao acaso e sem distinções" (Zingarelli, 1984: 755).

O termo fortuna - do latim fortuna, traduzindo o grego týche e com o significado, na mitologia, de sorte enviada pelos deuses e de acaso entendido como "a causa de fatos excepcionais, acidentais e finalizados" em Aristóteles (Gobry, 2007: 153) - é uma especificação de acaso no sentido daquilo que "traz aos homens alguma vantagem ou algum dano", isto é, boa ou má fortuna (Ciotti, 2006: 4.428-4.429). O termo teve também uma relação com a moral a partir de Cícero (106-43 a.C.), para quem a fortuna teria uma relação com a virtude, que permitiria suportar os efeitos da fortuna e atingir a tranquilidade, e de Sêneca (4 a.C.-65 d.C.), para quem a virtude era entendida como acordo e harmonia, capazes de enfrentar os acasos da fortuna com serenidade e força (Ciotti, 2006: 4.428-4.429). Por fim, o termo foi retomado pelos humanistas da Renascença, também associado ao conceito de virtude - por exemplo, no capítulo XXV do Príncipe de Maquiavel, em que esta seria uma "força e energia de realização" das ações humanas, que teria a função de "atingir os fins que se queira realizar", ou seja, a fortuna seria "a ocasião para o exercício da virtude" (Ciotti, 2006: 4.429). Como escrevia o próprio autor, "[a fortuna] demonstra toda a sua potência onde não estamos preparados para resistir-lhe pela virtude, onde, portanto, ela manifesta seu ímpeto" (Macchiavelli, 1960: 99).

Aqui destacaremos o sentido mais específico de risco - de acordo com o sociólogo François Ewald, adquirido, inicialmente, na esfera comercial, em que era entendido como "corolário da confiança e da garantia" e indicava também, no século XVI, "o rochedo que ameaçava as mercadorias de um navio durante sua viagem" (uma provável derivação do grego rhiza, rochedo) (La Providence de l'État, 2000). Entretanto, destaca Ewald, é somente nos anos 1970 que o 
termo entra na linguagem científica e se torna "uma variável sociológica significativa", devido à "proliferação de riscos [que] marca o advento de uma sociedade nova", e risco é definido como "modo de representação que atribui a determinado evento o estatuto de acidente, que implica um processo de reparação", podendo-se dizer que "a preocupação com o risco não é recente, ainda que a utilização do nome o seja, sobretudo em sua proliferação atual" (La Providence de l'État, 2000). Com efeito, já em Aristóteles se pode ver que "a cultura antiga está dominada pela ideia de que o homem é um animal destinado ao risco", o que fez com que "em torno da virtude central da phronesis se elaborasse toda uma moral da prudência, de deliberação diante da incerteza", pois se "a perfeição do mundo divino exclui o aleatório, o mundo humano, imperfeito, deve se realizar por meio de decisões humanas arriscadas" (La Providence de l'État, 2000).

Outro sociólogo - o já lembrado Ulrich Beck (1986) - considera o risco como uma característica estrutural das relações sociais, pois a produção de riqueza estaria sistematicamente correlacionada à produção social de risco, a qual reforçaria, por sua vez, a desigualdade social já existente.

Se analisarmos as várias ocorrências do termo risco, poderemos constatar que ele é utilizado, muitas vezes, como sinônimo de perigo, sobretudo devido a uma identificação sub-reptícia entre o chamado risco global - analisado, entre outros, por Beck (1986) - e sua atualização e identificação como perigo. Mas essa identificação pode gerar confusão, e a distinção entre risco e perigo é necessária, pois, afinal, os riscos são mais ou menos calculáveis em suas consequências não previsíveis - falando-se por isso em probabilidade de riscos -, ao passo que um perigo é algo real e constatável ou, então, foge do cálculo estatístico - não sendo, portanto, calculável, nem espaço-temporalmente nem socialmente. Pode, inclusive, contradizer as melhores previsões feitas pelo cálculo dos riscos. Um exemplo disso são as catástrofes nucleares.

\section{As Questões Conceituais Envolvidas pela Interface Bioética- Biossegurança}

No título deste ensaio consta a dupla conjunção e/ou, que, ao mesmo tempo, junta e separa os dois termos da relação, os quais se referem aos dois 
tipos de saber chamados bioética e biossegurança. Em termos lógicos, a relação estabelecida entre tais saberes é de conjunção-disjunção não excludente, pois ambos os termos se referem a problemas reais comuns - como podem ser os problemas ambientais e sanitários - e têm, portanto, o mesmo tipo de referente, constituído pela avaliação dos fatos biotecnocientíficos e suas possíveis consequências em termos de riscos e danos, ou seja, a preocupação comum tem a mesma compreensão semântica. Entretanto, tal referente comum não tem a mesma extensão, pois é também visto a partir de olhares diferentes representados pelo ponto de vista da bioética e por aquele da biossegurança. Mas tratando-se, também, de olhares que não se excluem entre si, porque é, como pretendemos, de fato possível estabelecer uma interface entre eles, que indicamos justamente pela conjunção e/ou.

Dito diversamente, a indicação que a dupla conjunção e/ou nos dá é que entre os dois saberes é possível estabelecer uma relação tanto de proximidade (entre as preocupações dos dois saberes diante dos problemas que constituem seus objetos e, talvez, também das intenções respectivas sobre como enfrentálos) quanto de afastamento entre os dois saberes, devido a diferenças específicas de cada saber que distinguem os dois saberes um do outro. Nesse sentido, a conjunção/disjunção e/ou indica que existe de fato um tipo de relação que pode ser indicado pelo termo interface (Schramm, 2010b), a qual pode ser entendida (de acordo com os dicionários) como elemento, área, fronteira ou meio compartilhados por saberes, sistemas, dispositivos e agentes (Houaiss \& Villar, 2001: 1.633).

Mas a abordagem deste produto de uma relação a que chamamos de interface bioética-biossegurança implica um método (do grego methodos, caminho) capaz de saber distinguir sem separar e juntar sem confundir e que - de acordo com Edgar Morin (1990) - seria o método necessário para abordar a complexidade e seus objetos de estudo. Uma interface pode ser vista como pertencente à caixa de ferramentas do paradigma da complexidade, entendido como quadro epistemológico, teórico e conceitual que serve para o estudo dos fenômenos humanos e sociais, produzido com base na teoria dos sistemas e do construtivismo e em três princípios: 
1) o princípio dialógico, que pretende ultrapassar "os antagonismos em uma construção superior";

2) o princípio da recursividade, que permite encarar "os efeitos circulares e em anel que afetam todo fenômeno humano";

3) o princípio hologramático, que "põe em evidência que o todo está na parte como esta se reencontra no todo" (Mucchielli, 2011b: 23-24).

A vantagem de inscrever a interface bioética-biossegurança no âmbito do paradigma da complexidade é a de considerar bioética e biossegurança como saberes normativos parcialmente autônomos do ponto de vista disciplinar, embora tais saberes estejam também vinculados entre si por uma relação que pode ser de tipo interdisciplinar e até transdisciplinar, se considerarmos que problemáticas como a do risco ou aquela ligada à moralidade da biotecnociência atravessam os dois campos de saber. Se o que estamos afirmando está correto, pode-se dizer que ambas as caixas de ferramentas - representadas pela bioética e pela biossegurança - podem, por um lado, "ser aplicadas para avaliar e controlar os produtos da biotecnociência" e, por outro, ter "finalidades diferentes: o controle e a segurança das práticas e dos produtos da biotecnociência (...) para a biossegurança; a legitimidade e a justificação normativa para a bioética" (Schramm, 2010b).

A interface bioética e biossegurança pode ser enxergada, por exemplo, quando ambos os tipos de saberes se referem a alguma forma de controle das práticas da biotecnociência, devido a uma real ou suposta periculosidade, presente ou futura, de seus procedimentos (como a nanotecnologia) e produtos (como as biotecnologias). Por isso, a relação de interface bioética-biossegurança permite lidar com os problemas engendrados pela periculosidade e que dizem respeito também a valores, comportamentos e juízos, justamente os objetos específicos da bioética - ou da ética ambiental, segundo Shrader-Frechette (1990). Parece, portanto, correto pensar que bioética e biossegurança se ocupem dos mesmos assuntos (como os vários tipos de riscos e perigos) e com ferramentas de análise que podem ser compartilhadas, como a avaliação tecnológica, a percepção social dos danos e riscos envolvidos, assim como a ponderação entre probabilidade de riscos e de benefícios esperados. 
Entretanto, bioética e biossegurança são também caixas de ferramentas com identidades e funções distintas, pois a bioética se refere à moralidade da prática biotecnocientífica e, com base em sua análise, propõe normas de conduta consideradas consensualmente (ou por negociação) corretas. Ou seja, analisa a cogência - entendida como o que é racionalmente necessário e que constrange -8 dos argumentos favoráveis e contrários ao seu uso; pondera suas possíveis e prováveis consequências, avaliadas dos pontos de vista da prevenção e da proteção da saúde e do bem-estar de indivíduos e populações humanas (podendo-se em princípio incluir animais não humanos e ambientes naturais encarados de um ponto de vista sistêmico). A partir daí, propõe formas de agir que possam ser consideradas moralmente corretas por qualquer agente moral ideal dito racional e imparcial. Por sua vez, a biossegurança pode ser vista como

o conjunto de ações voltadas para a prevenção, minimização ou eliminação de riscos inerentes às atividades de pesquisa, produção, ensino, desenvolvimento tecnológico e prestação de serviços, visando à saúde do homem, dos animais, à preservação do meio ambiente e à qualidade dos resultados. (Teixeira \& Valle, 1996: 13)

Assim, parece que a questão metodologicamente correta a se enfrentar está em saber o que distingue, mas não separa, e junta, mas não confunde, a bioética e a biossegurança, o que pode ser indicado tanto pelo termo genérico vínculo como pelo termo mais técnico interface - entendida como aquela linha ou espaço que separa dois objetos ou campos e, dessa forma, permite também que entrem em contato entre si, mas mantendo sua identidade própria, para que os dois tipos de saber possam de fato se comunicar entre si e, em princípio, cooperar, e não ser subsumidos um ao outro. Sem essa preocupação conceitual e metodológica - consistente em perguntarmos o que distingue e vincula bioética e biossegurança - não poderíamos falar corretamente em interface, pois o que haveria seria, na melhor das hipóteses, mera justaposição disciplinar (que pode assumir o caráter de uma relação dita multidisciplinar e, eventualmente, pluridisciplinar), ou, na pior, confusão entre dois saberes que têm,

\footnotetext{
${ }^{8}$ Do ponto de vista da lógica, a cogência é a qualidade apresentada por argumentos dedutivamente legítimos baseados em premissas verdadeiras e que levam a conclusões verdadeiras. Trata-se de um termo utilizado sobretudo em direito com o sentido de racionalmente necessário (Hegenberg, 1995: 35-36, destaques do original).
} 
também, suas identidades próprias, ou a subsunção de um campo ao outro. No caso específico: da bioética à biossegurança, entendendo a primeira, por exemplo, como mero suporte moral para as ações concretas da biossegurança. Pode-se também pensar numa subsunção da biossegurança à bioética, no sentido de aquela se tornar uma espécie de executora dos princípios e normas desta.

Supondo esclarecida a questão das relações lógico-conceituais entre bioética e biossegurança, e aquela dos possíveis vínculos entre estas no contexto da finalidade pragmática de resolver controvérsias morais, faltaria ainda saber se bioética e biossegurança têm competência, tanto cognitiva como moral, para evitar riscos e, caso afirmativo, em que condições. Nesse caso, a pergunta pragmática decorrente deve ser aquela que questiona se as ferramentas da bioética e da biossegurança são, juntas, de alguma utilidade prática para evitar as formas de conflituosidade ocasionadas pela percepção dos riscos vigentes em nossas sociedades globalizadas, sobretudo considerando que tais riscos são de fato estruturais e produzidos pelas nossas formas de viver e conviver.

De acordo com a percepção surgida no pós-guerra, as sociedades atuais são sociedades de risco e sociedades que produzem riscos, discutem sobre risco, tentam prevê-los e geri-los; nelas, "a generalização dos riscos (...) instaura um estado de urgência ilimitado, que transcende a esfera nacional para se tornar universal" (Beck, 2008), podendo-se até dizer que "a sociedade do risco é por natureza mundial (Weltrisikogesellschaft)" (Beck, 2006: 1.007). Mas tal entendimento implica também a necessidade de mais segurança contra todo tipo de risco, tanto real como imaginário, o que afeta a própria qualidade das relações sociais, que se tornam muitas vezes relações de risco e desconfiança generalizada, instaurando uma espécie de paranoia social e, consequentemente, criando as condições para um estado de exceção generalizado.

A questão em foco é bastante complexa, não somente devido à frequente (e já lembrada) confusão entre risco e perigo, mas também porque há vários conflitos chamados riscos, que o sociólogo Ulrich Beck classifica em três tipos:

1) os riscos ecológicos, como as catástrofes climáticas que apresentam "caráter de ameaça física" e são praticamente incontroláveis; 
2) os riscos econômicos globalizados, como a atual crise econômica e financeira - que leva à "situação paradoxal" em que "os mercados são mais liberalizados e globalizados" - e as instituições globalizadas, que deveriam controlar seus efeitos, "devem enfrentar uma limitação drástica de seu poder";

3) os riscos representados pelas chamadas "redes terroristas globalizadas", que levariam a uma "cultura ansiogênica autoparalisante, que corre grande risco de derrubar os próprios fundamentos da liberdade e da democracia" (Beck, 2006: 1.007-1.008).

Para Beck, essa incapacidade de dar conta dos três tipos de risco, assim como a convergência entre eles, teria consequências sociais significativas. O próprio tipo de socialização se transformaria: a tradicional integração "positiva baseada em valores e normas compartilhados" seria substituída por "um novo tipo de integração", resultante de uma "efetivação de conflitos" baseada em "valores negativos", como crises e "perigos de aniquilamento", o que faria com que o espaço público se cristalizasse "menos em torno destas ou daquelas decisões particulares, e mais das consequências perigosas resultantes e percebidas como tais" (Beck, 2006: 1.008). A suspeita (ou paranoia) parece generalizar-se, em um contexto no qual "o Estado providência mostra claramente seus limites, devido à sua incapacidade de continuar garantindo a proteção dos cidadãos", o que pode até ser interpretado como uma "ruptura do contrato social que a razão havia inventado para definir os direitos e os deveres" (Kermisch, 2007a: 8).

Cabe pensar, entretanto, que, visto que "os perigos não são simplesmente perigos" e que "os riscos globais liberam um momento de reflexão e de comunicação", eles podem ter também - pelo menos indiretamente - efeitos positivos, como poderia ser a criação de um espaço público caracterizado pela "emergência de uma consciência normativa global [e de] um olhar cosmopolita sobre as coisas" (Beck, 2006: 1.008-1.009).

Se introduzirmos a palavra risco - entendido como uma espécie de referente comum à bioética e à biossegurança - surge o problema, já detectado a respeito da ética ambiental, da suposta proximidade semântica entre risco e dano. De fato, as duas palavras nem sempre são devidamente distinguidas 
na linguagem do senso comum, o qual utiliza também a palavra perigo (que parece indicar uma espécie de meio-campo ou síntese entre risco e dano, ou um risco particularmente intenso).

Conceitualmente, risco não corresponde em sentido estrito a dano, e se refere a uma percepção presente de um provável dano futuro. Ou seja, o conceito de risco necessariamente se refere ao tempo (em geral num futuro mais ou menos próximo) e é, portanto, inseparável de nossa ignorância sobre aquilo que, "de diversas formas, ameaça causar dano", sendo então "uma função de incerteza cognitiva referida à presença de um perigo". Ou seja, risco refere-se "à possibilidade de um dano" presente ou futuro; e dano se refere sempre ao tempo presente, ou seja, "uma ameaça certa ou um prejuízo que certamente acontecerá" (Engelhardt Jr., 2005: 133). Pode, inclusive, referir-se a alguma forma de fim dos tempos (como costumam indicar películas de ficção científica), o que eventualmente implicará a necessidade de alguma teodiceia capaz de "dar sentido a esse escândalo da existência do mal em um mundo que procede em princípio de uma criação perfeita" (Dupuy, 2005: 37).

Essa necessária distinção entre risco e dano (como aquela entre risco e perigo) é importante tanto para a bioética como para a biossegurança (e a ética ambiental), pois sem ela podem-se confundir âmbitos de pertinência distintos, embora estes não sejam separados, como tentamos mostrar aqui ao falar da interface bioética e biossegurança. Em particular, a distinção é importante para a reflexão ética em uma sociedade em que a questão da segurança parece justificar medidas autoritárias, senão totalitárias. Vejam-se, como exemplo, algumas medidas preventivas contra o assim chamado terrorismo após o 11 de setembro de 2001, quando "um evento apocalíptico se produziu em solo americano [e] um aspecto do mal foi espetacularmente revelado, senão criado, aos olhos do mundo", como se se tratasse de um ato "que tinha um objeto e que os autores do crime tivessem razões" para levá-lo a cabo, em vez de se considerar - como sugere Dupuy - "que as torres gêmeas de Manhattan não eram o objetivo ao qual se lançavam os aviões de linha desviados, mas o obstáculo fascinante que os atraía como faz a luz de uma lâmpada com as borboletas noturnas". Não se considerou que se tratava de uma "naturalização do mal", e que este "é de inteira responsabilidade dos homens", pois "não existe mal natural e físico", e isso corresponde "à convicção que está na base da separação, que ainda 
mantemos desesperadamente, entre o mundo da natureza, sem intenções nem razões, e habitado somente por causas, e o mundo da liberdade, onde as razões para agir estão sob a jurisdição da lei moral" (Dupuy, 2005: 61-68).

A seguir, tentaremos analisar as possíveis razões práticas para estabelecer uma interface entre bioética e biossegurança, e verificar se ela se justifica na vigência daquilo que chamamos de paradigma biotecnocientífico - termo que indica, em substância, o fato de os saberes atuais sobre os organismos vivos apresentarem dois aspectos indissociáveis: um aspecto logoteórico, característico das ciências que se preocupam com o avanço dos conhecimentos sobre a bioesfera; e um aspecto biotécnico, característico das técnicas e dos dispositivos que se preocupam com a aplicação prática (ou pragmática) dos conhecimentos científicos ao mundo da vida.

\section{Razões Práticas da Interface Bioética-Biossegurança}

Da maneira mais sintética possível, pode-se afirmar que existe uma interface entre bioética e biossegurança porque ambos os saberes têm uma preocupação prática comum que os aproxima, como aquela de proteger populações humanas em situação de risco (e eventualmente de perigos), lançando mão de medidas e dispositivos, considerados necessários, legítimos e efetivos para se atingir o objetivo comum de dar amparo a quem precisa. Medidas e dispositivos que devemos considerar em seus ambientes respectivos - simultaneamente de tipo natural, cultural e social - e podem ser também de tipo moral e institucional. Um dispositivo - de acordo com a já lembrada definição de Foucault (2004a) - se refere a um conjunto heterogêneo formado por discursos, instituições, práticas, regulamentos, leis e medidas administrativas, inclusive "enunciados científicos, proposições filosóficas, morais, filantrópicas", ou seja: "o dispositivo é a rede que se pode estabelecer entre tais elementos" (Revel, 2008: 41-42). Na interpretação de Giorgio Agamben, trata-se sempre também de instrumento de poder que tem "a capacidade de capturar, orientar, determinar, interceptar, modelar, controlar e assegurar os gestos, as condutas, as opiniões e os discursos dos seres vivos" (2006: 22).

A definição de interface como "elemento que proporciona uma ligação física ou lógica entre dois sistemas [que] não poderiam ser conectados diretamente" 
ou como "área em que coisas diversas (dois departamentos, duas ciências etc.) interagem" (Houaiss \& Vilar, 2001: 1.633) nos obriga também a identificar e distinguir o papel respectivo de cada saber.

A bioética é constituída por "um conjunto de pesquisas, discursos e práticas, geralmente pluridisciplinares" - ou, se preferirmos, interdisciplinares - que têm por objetivo "esclarecer ou resolver questões de alcance ético, suscitadas pelo avanço e pela aplicação das tecnociências biomédicas" (Hottois, 2001b: 124) e, portanto, também uma função descritiva e uma função normativa (ou prescritiva e proscritiva) dos conflitos e controvérsias morais, tentando "desenvolver uma reflexão que inspire os atos sociais para desenvolver as transformações necessárias" (Kottow, 2009: 133).

A biossegurança, baseada em alguma descrição cientificamente fidedigna dos riscos e perigos (que pode eventualmente ser compartilhada pela bioética entendida como saber interdisciplinar), lança mão, sobretudo, de dispositivos que tenham amparo jurídico, como é o caso dos protocolos de biossegurança que regulam as trocas de organismos geneticamente modificados (OGMs) entre Estados ${ }^{9}$ ou das leis de biossegurança, como a lei de biossegurança brasileira (Brasil, 2005). ${ }^{10}$ De fato, tais dispositivos servem para coibir os comportamentos ditos de risco ou considerados literalmente danosos, como veremos a seguir apresentando sua percepção pelo imaginário social, entendido como o lugar onde se constrói "a articulação entre a apreciação coletiva, os valores que a ordenam, as considerações sociais que a determinam, os modos que a marcam e as lógicas [envolvidas], bem mais difíceis de entender que a apreciação individual" (Corbin, 2006: 1.062).

\footnotetext{
${ }^{9}$ É o caso do Protocolo de Cartagena sobre Biossegurança, adotado em Montreal em 2000, em vigor desde 2003 e assinado pelo Brasil em 2004, que "tem como objetivo geral contribuir para assegurar um nível adequado de proteção no campo da transferência, da manipulação e do uso seguro dos organismos vivos modificados (OGM), resultantes da biotecnologia moderna, que possam ter efeitos adversos na conservação e no uso sustentável da diversidade biológica, levando em conta os riscos para a saúde humana". Disponível em: <www.cdb.gov.br/cartagena>. Acesso em: 7 jun. 2014.

${ }^{10}$ Ver lei n. 11.105, de 24 de março de 2005, que em seu artigo 1ำ estabelece "normas de segurança e mecanismos de fiscalização sobre a construção, o cultivo, a produção, a manipulação, o transporte, a transferência, a importação, a exportação, o armazenamento, a pesquisa, a comercialização, o consumo, a liberação no meio ambiente e o descarte de organismos geneticamente modificados - OGM e seus derivados, tendo como diretrizes o estímulo ao avanço científico na área de biossegurança e biotecnologia, a proteção à vida e à saúde humana, animal e vegetal, e a observância do princípio da precaução para a proteção do meio ambiente" (Brasil, 2005).
} 


\section{A questão dos riscos e sua 'construção social'}

Os riscos podem ser de vários tipos. Em primeiro lugar, há aqueles propriamente naturais - que podem ser abordados tanto pela biossegurança quanto pela ética ambiental que julga que o mundo natural não humano é digno de consideração moral, não somente por ser o meio em que os humanos vivem, mas também por ter alguma forma de valor em si mesmo e porque a ação humana pode transformá-lo radicalmente. Os riscos ditos naturais podem ser vistos, em princípio, como independentes da ação humana (como as catástrofes naturais), porém cada vez mais como produto (pelo menos indireto) de sinergias entre os fenômenos naturais e a ação humana. Há também os riscos dependentes diretamente da ação humana, como aqueles resultantes de determinado uso da biotecnociência, como no caso das guerras químicas ou bacteriológicas, passando pelos riscos associados ao chamado bioterrorismo ou terrorismo químico-biológico, entendido-por exemplo, no campo da saúdecomo "a liberação intencional de produtos químicos ou agentes infecciosos prejudiciais à saúde e ao meio ambiente" (Portal Fiocruz, 2014). Por fim, podese incluir, no campo dos riscos, a utilização, por parte de Estados, dos "progressos da biologia molecular para criar novas armas de guerra", mas sabendo-se que há "toda uma gama de pontos de vista mais ou menos autorizados, desde o discurso apocalíptico até as declarações mais tranquilizadoras", que alimentam "cenários catastróficos muitas vezes apresentados pelas instituições mais respeitáveis" (La Recherche, 2014).

A construção social do risco é algo importante tanto do ponto de vista bioético como do ponto de vista biopolítico, pois implica, muitas vezes, verdadeiras controvérsias ou polêmicas entre "legitimidades, narrativas, representações, que farão a adesão da população oscilar em favor de um ou de outro campo" (Bricet \& Vallons, 2010: 11). Pode implicar, também, a ideia de que a suposta existência da sociedade de risco global justifique um "estado de exceção" permanente que, segundo Giorgio Agamben (2004: 13), constituiria "o paradigma de governo dominante na política contemporânea", o que leva a considerar - implícita ou explicitamente - liberdades fundamentais como fatores de risco a serem eliminados ou, pelo menos, controlados (ou vigiados e punidos). 
Em tal cenário, a imagem que vem à mente é aquela do Leviatã de Thomas Hobbes - com plenos poderes sobre todos os indivíduos da sociedade do risco global e legitimidade moral e política suficiente para responder ao medo generalizado que submete as pessoas ao déspota e renunciar, assim, à liberdade em nome da segurança (Hobbes, 2002). Esse "novo" Leviatã seria, portanto, encarregado da gestão política das emoções suscitadas pela alta probabilidade dos riscos, ao mesmo tempo locais e globais, lançando mão de medidas coercitivas para supostamente proteger as pessoas ameaçadas, mesmo ao custo de estas terem que abrir mão de boa parte de seus direitos, a começar pela liberdade. E o argumento principal utilizado é de que essa seria a única medida capaz de evitar que a globalização do risco se torne uma catástrofe concreta para todos e de todos contra todos, isto é - no fundo - uma "globalização dos danos [que] resulta na globalização do ressentimento e da vingança" (Bauman, 2007: 126).

Mas a construção social dos riscos e a globalização de perigos, danos, ressentimento e violência têm a ver, em muitos casos, com a própria percepção social da biotecnociência, suas possibilidades, riscos e perigos; em geral, as vantagens são sublinhadas quase sempre pelos pesquisadores e jornalistas científicos, e a periculosidade por militantes e grupos sociais organizados - ambos os movimentos tentando formar a opinião pública em geral (Pyrrho, 2008).

\section{Mas, afinal, a biotecnociência é perigosa?}

A questão da periculosidade da biotecnociência pode ser abordada tanto pelas ferramentas da biossegurança como por aquelas da bioética, mas sabendo-se que a bioética se ocupa em primeiro lugar de conflitos e controvérsias morais que ela tenta descrever e resolver em princípio racionalmente (e sem esquecer os vínculos entre razão e emoção), construindo convergências normativas por meio de um agir comunicativo capaz de levar às transformações consideradas necessárias. A biossegurança, por sua vez, se ocupa da gestão dos riscos lançando mão das medidas concretas a serem tomadas, inclusive de tipo legal, para, por exemplo, proteger a população contra substâncias biológicas e bioquímicas perigosas. Com relação ao saber-fazer da biotecnociência, tanto a biossegurança quanto a bioética se preocupam com seus possíveis desdobramentos em termos de riscos e danos, o que justificaria falarmos 
em interface de bioética e biossegurança em suas abordagens respectivas da periculosidade da biotecnociência, de seus produtos e procedimentos.

Mas o termo interface se justifica ainda por outra razão. Por exemplo: quando pensarmos que a biossegurança pode precisar de alguma forma de legitimação valorativa, que pode ser encontrada graças às ferramentas da bioética, para justificar seus procedimentos de gestão e controle, e porque a bioética, por sua vez, pode encontrar na atuação da biossegurança uma espécie de aliado, o que pode responder aos anseios ao mesmo tempo identitários e pragmáticos da própria bioética. Se isso que estamos dizendo for correto, pode-se afirmar, em síntese, que a bioética analisa a moralidade das biotecnologias, e a biossegurança calcula, pondera e gere os riscos inerentes às biotecnologias.

Entretanto, tanto a bioética quanto a biossegurança devem se referir àquele que podemos chamar de campo tensional onde se dão as percepções sociais dos fatos da biotecnociência.

\section{O campo tensional das percepções sociais da biotecnociência}

O campo das percepções sociais das práticas biotecnocientíficas reúne considerações axiológicas (ou valorativas) e tentativas de estratégias políticas (ou biopolíticas), e está dividido, grosso modo, entre dois extremos, que consideram - juntos - a biotecnociência como "motivo de fascínio e de espanto" (Schramm, 1997: 217). Em outros termos, há um campo tensional entre dois grupos polarizados. De um lado, aqueles que constituem o universo dos tecnófilos (ou tecnofílicos) - para os quais qualquer nova tecnologia e biotecnologia constituiria um progresso, sendo, portanto, bemvinda, pois "tudo aquilo que faz a finitude do homem é rebaixado à condição de problema que a ciência, a técnica, a engenhosidade humana permitirão, cedo ou tarde, resolver" (Dupuy, 2005: 29), e sem se preocupar muito com seus eventuais efeitos negativos presentes ou futuros. De outro, os tecnófobos (ou tecnofóbicos) - para os quais a biotecnociência estaria, em última instância, desenvolvendo uma forma de poder capaz de transformar o mundo e o próprio homem indevidamente, prejudicando, inclusive, os melhores interesses tanto das gerações futuras como da própria humanidade do homem presente. 
De fato, a reflexão ética - mas também, mutatis mutandis, a sociológica e a antropológica - deve se situar entre esses dois extremos e se confrontar, por um lado, com "a angústia gerada pelo catastrofismo ambiente e a diabolização do progresso tecnológico" e, por outro, com as "pressões dos partidários de um reforço dos procedimentos de controle", que implicam uma gestão racional dos riscos e a explicitação dos valores capazes de definir um "patamar de aceitabilidade do risco". Em resumo, é preciso que tal reflexão "não seja apenas normativa, mas favoreça também uma reconciliação do homem consigo mesmo e com as técnicas das quais tem perdido o controle", analisando, inclusive, "as consequências morais" da atual incerteza reinante (Kermisch, 2007a: 9-10). Nesse sentido, a bioética poderia aproximar-se de algo como um "método de catastrofismo esclarecido" capaz de "tratar as catástrofes futuras [como] uma fatalidade, que não resulta de nenhuma intencionalidade humana, mas de um destino ou de uma fatalidade que [no entanto] somos livres para afastar" (Dupuy, 2005: 28).

Nesse campo tensional, entre os dois extremos há pelo menos três posições intermediárias, não necessariamente antitéticas, que podem ter uma relação de interseção.

A primeira posição é aquela dos adeptos do princípio de precaução, que - como vimos no segundo ensaio - defendem a diretriz de se abster de uma ação quando esta pode ter consequências danosas para os possíveis envolvidos. Trata-se de um princípio segundo o qual

a ausência de certezas, e tendo em conta os conhecimentos científicos e técnicos do momento, não deve retardar a adoção de medidas eficazes e proporcionais com vista a prevenir um risco de danos graves e irreversíveis no ambiente, a um custo economicamente aceitável. (Godard, 2001: 650)

O princípio de precaução tem a ver - em sua tentativa de racionalização da gestão dos riscos - com o bom senso e "a exigência de ações precoces e proporcionais" que acompanhem os desdobramentos da incorporação de novas tecnologias "através de uma revisão permanente das medidas de precaução iniciais" (Kermisch, 2007a: 10). Embora retome parcialmente o sentido da phronesis platônica - entendida como inteligência e pensamento puro no 
Fédon e considerada n'A República como uma das quatro virtudes cardeais, junto com a justiça, a coragem e a temperança - e o sentido de prudência aristotélica - entendida como discernimento moral ou "sabedoria prática, ou conhecimento das finalidades próprias da vida", considerada distinta "do conhecimento teórico e do simples raciocínio instrumental, ou perícia" e "uma condição necessária e suficiente da virtude" (Blackburn, 1997a: 297) -, trata-se de um princípio moral polissêmico e sui generis, que pode se mostrar, portanto, de pouca utilidade prática.

Com efeito, da maneira como é normalmente utilizado, tal princípio não se refere a probabilidades de ocorrência de danos claramente identificáveis; não especifica sua natureza; $\mathrm{e}$, sobretudo, se o adotássemos de forma indiscriminada, nunca teríamos o necessário grau de certeza com relação aos fatos da biotecnociência que podem ter consequências negativas, ou não, por falta de experiência, a qual só pode se dar diretamente (por exemplo, durante uma catástrofe) ou indiretamente (por exemplo, em laboratório, simulando catástrofes). Ademais, o princípio de precaução não tem - devido à sua polissemia - uma única definição compartilhada, pois

cobre um leque heterogêneo de concepções, o que certamente tem facilitado sua rápida adoção pela opinião pública - cada qual podendo dar-lhe um conteúdo de acordo com sua definição das prioridades e dos valores [envolvidos], (...) [embora a própria] etimologia do termo 'precaução' evidencie duas correntes maiores de interpretação, [pois o] termo latino praecaveo significa, por um lado, 'ser precavido' e, por outro, 'ter cuidado, velar por'. (Pinsart, 2007: 161)

Por isso, seus adeptos devem responder às críticas que consideram o princípio precautório (como é também chamado) como um empecilho à ação. Segundo tais críticas, esse princípio é utilizado, no fundo, contra o desenvolvimento e as mudanças, considerados necessários para a própria sobrevivência da espécie humana, e no mundo em rápida transformação em que vivemos sua aplicação poderia resultar numa inação questionável do ponto de vista tanto moral como político (Balistreri, 2002).

Em outros termos, o princípio de precaução é aparentemente capaz de evitar perigos e danos, legiferando, por exemplo, sobre as ameaças do aquecimento climático, o esgotamento dos recursos naturais, as crises ambiental e energética, 
assim como sobre os problemas de saúde pública envolvidos. Mas, em realidade, "o saber a respeito dessas ameaças, algumas das quais são gravíssimas, não incita ninguém a agir, e isso porque não conseguimos representar as implicações daquilo que sabemos", porque "não basta saber para aceitar o que sabemos e agir consequentemente" e também porque, "mesmo quando sabemos de fonte certa, não conseguimos acreditar no que sabemos", razão pela qual se pode dizer que "os promotores do princípio de precaução ainda não compreenderam essa verdade básica". Por isso,

[dever-se-ia] questionar a ideia, recebida com demasiada facilidade, de que é diante das gerações futuras que devemos responder pelos nossos atos, [pois] o recurso à linguagem dos direitos, dos deveres e da responsabilidade para tratar 'nossa solidariedade com as gerações futuras' levanta problemas conceituais consideráveis, que a filosofia ocidental se revelou, no essencial, incapaz de esclarecer. (Dupuy, 2005: 11-22)

A segunda posição, mais incisiva e de origem kantiana e weberiana, se baseia, de acordo com a proposta de Hans Jonas ([1979] 2006), no princípio de responsabilidade, que o autor opõe a um suposto niilismo reinante nas sociedades democráticas, individualistas e multiculturais atuais, defendendo uma ética que seja capaz de orientar as decisões nos campos da tecnociência e da medicina, e voltada, sobretudo, para o que pode ser visto como "o impacto do desenvolvimento tecnocientífico atual sobre a concepção que o ser humano faz de si mesmo" (Pinsart, 2007: 159).

A ética da responsabilidade decorrente preocupa-se, sobretudo, com o futuro da espécie humana e o impacto das ações humanas sobre os processos naturais e sociais, considerados cada vez mais ameaçados e ameaçadores. Em outros termos, o desenvolvimento tecnológico implicaria um risco tecnológico com um "alcance espaço-temporal longo" e "efeitos incertos e potencialmente ameaçadores para a sobrevivência da espécie humana e suas condições de existência" (Pinsart, 2007: 160).

O pressuposto de Jonas é uma ontologia e uma filosofia da natureza que consideram - de acordo com a tradição aristotélica - que a evolução dos processos vitais é orientada por um finalismo intrínseco a ser absolutamente respeitado por nós, que teria culminado no surgimento da espécie Homo 
sapiens sapiens, ou "ser dos fins", capaz de inventar e realizar projetos corretos de maneira livre e intencional. Por isso, a ética da responsabilidade implicaria uma política pensada por homens prudentes, preocupados em proteger a existência humana a longo prazo e sabedores de que a sobrevivência do ser humano depende da preservação dos processos naturais, e não tanto de suas transformações.

Como se pode ver, o princípio de responsabilidade tem uma evidente interseção com o princípio de precaução, pois ambos compartilham a desconfiança diante das ações tecnocientíficas e das incertezas envolvidas pelo saber-fazer tecnocientífico. Pode-se, portanto, dizer que "[o] princípio de precaução e o princípio de responsabilidade se encontram em sua tomada de consciência dos riscos tecnocientíficos que pesam sobre a vida atual e futura do ser humano, assim como sobre o ambiente" e que, afinal, os "dois princípios têm sua origem em uma atitude reativa" (Pinsart, 2007: 161). Entretanto, deve-se também ressaltar que Jonas nunca utiliza o termo princípio de precaução - provavelmente por não considerá-lo propriamente um princípio -, mas recorre à expressão "progresso com precaução", pois considera que

nada daquilo que dissemos (...) deveria ser compreendido como um desestímulo [a] qualquer (...) progresso técnico, apesar de constituir um tema recorrente, para nós, o perigo de que esses poderes caiam nas mãos da avidez e da mesquinharia humanas (e mesmo da miséria humana!). (Jonas, [1979] 2006: 306-307)

Mas Jonas - e nisto ele se distancia das posições de seu mestre Heidegger não é contra o progresso tecnocientífico, pois o considera "uma necessidade para responder às necessidades de uma população em rápida expansão, para reparar os danos ambientais e encontrar alternativas às indústrias poluidoras" (Jonas, [1979] 2006: 160).

Entretanto, apesar de ter tido o mérito de destacar a responsabilidade para com o mundo e as gerações futuras e o decorrente engajamento nas questões práticas, o problema da ética jonasiana está em sua concepção metafísica da evolução. Tal concepção desconsidera a contingência e o acaso dos processos naturais, substituídos por um finalismo intrínseco (de origem aristotélica), supostamente evidente, que orientaria teleologicamente a própria evolução como um todo e interditaria ao humano intervir nesse suposto finalismo 
intrínseco de sua própria evolução e naquele dos outros sistemas e processos vivos, para evitar possíveis catástrofes que aniquilariam o próprio Homo sapiens, o qual teria se tornado incapaz de se adaptar a tal finalismo.

Outro tipo de crítica, recebida por Jonas, refere-se especificamente a sua proposta de uma heurística do medo, entendida como algo que deveria fazer parte da ética do futuro e decorreria do fato de que "o reconhecimento do malum é infinitamente mais fácil do que o do bonum", pois, por ser "mais imediato, mais urgente, bem menos exposto a diferenças de opinião, ele não é procurado: o mal nos impõe a sua simples presença, enquanto o bem pode ficar discretamente ali e continuar desconhecido, destituído de reflexão" razão pela qual, "para investigar o que realmente valorizamos, a filosofia da moral tem de consultar o nosso medo antes do nosso desejo" (Jonas, [1979] 2006: 70-71).

Embora reconhecida como "um dos traços mais originais e surpreendentes do pensamento de Hans Jonas", sua heurística do medo é também criticada, porque ao considerar o medo tanto como um "princípio do conhecimento" que teria uma "eficácia heurística" - quanto como "um princípio da prática, e mais exatamente da prática política" - que teria uma "eficácia política" -, Jonas misturaria os dois conceitos de ameaça e de perigo (Sève, 1993: 107). Mas os dois conceitos se referem a dois tipos de realidade diferentes, pois ameaça indica a possibilidade de alguém ser atingido, ao passo que perigo indica uma realidade constituída pela presença imediata de um mal que pode atingir pessoas. Ou seja, porque "uma ameaça remete a um mal efetivo", ao passo que um "perigo remete, antes, à realidade objetiva dessa possibilidade de ser atingido". $\mathrm{O}$ "medo [é] causado diretamente pela ameaça, e indiretamente pelo mal ameaçador", e, nesse caso, se trataria de dois níveis de realidade: a "realidade do mal" e a "realidade de sua ameaça", uma vez que "se a presença efetiva do mal, que produz a aversão ou a rejeição, é uma presença imediata, indiscutível, a ameaça do mal, a consciência do perigo, passa pela mediação de uma representação [do] objeto perigoso e ameaçador". Pode-se, portanto, concluir que tal "sentimento [é] suscetível dos mesmos graus, das mesmas intensidades e também das mesmas incertezas ou deformações que as representações sobre as quais ele se apoia" (Sève, 1993: 108). 
É por isso que deveríamos saber "distinguir muito claramente as duas noções de heurística do medo e de antecipação da ameaça, que estão no cerne do pensamento de Jonas" (Sève, 1993: 108). Por exemplo, pode-se duvidar, por um lado, da "possibilidade de estender essa potência heurística a perigos apenas imaginados e que não têm nenhuma analogia com nossa experiência real" e, por outro, "[a] própria ideia de antecipação implica uma fixação na experiência real, por derivação causal ou figuração analógica"; "na falta dessa fixação, a antecipação corre o risco de ser arbitrária, fantasmática, e não merecer ser levada em conta", ou seja, "a validade da heurística do medo não pode (...) ultrapassar os limites da analogia com nossa experiência real". Por isso, para Jonas, a humanidade teria o dever de "antecipar ao máximo os perigos escondidos em seus comportamentos presentes", mas sabendo, também, que "antecipar uma ameaça absolutamente inédita não é possível: e, no entanto, para Jonas, são justamente as ameaças desse tipo que seria mais importante conseguir antecipar" (Sève, 1993: 112-113).

A terceira posição considera que a biotecnociência pode ser, sob determinadas condições, benéfica para os humanos presentes e futuros, no sentido de constituir um meio a serviço dos ideais morais e políticos de justiça, igualdade e emancipação.

Formulada por Karl-Otto Apel e Jürgen Habermas, é conhecida como ética procedimental da discussão e baseia-se em um tipo de argumentação em princípio sem restrições (ou exclusões) a todos os envolvidos em uma controvérsia moral. Seu pressuposto é que todos tenham igualmente por objetivo o consenso racional, o qual, adotado livremente por todos os interessados, seja capaz de evitar tanto medidas autoritárias que desrespeitam os direitos humanos (Apel, 1987) quanto o eugenismo de tipo liberal (Habermas, 2001).

Embora essa posição possa ser vista como uma tentativa de evitar as críticas feitas à ética da precaução e à ética da responsabilidade, ela pode também ser criticada - como fez Gilbert Hottois (2005: 112) - devido, essencialmente, à sua característica considerada idealista, visto que ela considera que a única forma de emancipação humana seja de tipo simbólico (ou comunicativo), e não também de tipo "tecnomaterial". 
A segunda característica que pode ser criticada - ainda de acordo com Hottois (2005) - é seu conservadorismo naturalista (compartilhado com a ética da responsabilidade de Jonas) e, no fundo, sua concepção negativa da técnica. Mas isso a tornaria incapaz (e nisso ela se distanciaria da ética jonasiana) de ver nas intervenções biotecnológicas meios para reduzir as desigualdades humanas, inclusive no momento de nascer.

Em outros termos, a ética procedimental da discussão seria criticável porque, embora evite as críticas feitas tanto ao princípio de precaução como à responsabilização jonasiana, por um lado ela reconheceria corretamente o poder dialógico da comunicação (não reduzida à mera transmissão de informação), mas, por outro, desconheceria as próprias potencialidades emancipatórias da biotecnociência, apesar de não recusar a priori algumas delas. Ou seja, a ética procedimental da discussão é questionável porque parece desconhecer a possibilidade que a biotecnociência teria de transformar e capacitar a própria natureza humana, em vez de considerá-la como bode expiatório dos males de nossa civilização tecnocientífica globalizada.

Feitas essas considerações críticas sobre o meio-campo entre tecnofilia e tecnofobia, falta ainda dizer algo específico sobre a pertinência e a justificativa de a bioética avaliar o progresso tecnológico e biotecnológico, e tentar mostrar em que consistiria tal avaliação bioética.

\section{Pertinência da Avaliação Bioética do Progresso Tecnológico}

Em uma sociedade complexa e democrática, há muitas maneiras pertinentes e legítimas de avaliar (ou estimar) as consequências sociais das tecnologias (como os vários tipos de risco) e o possível progresso envolvido (como aquele da biomedicina e o da engenharia genética).

A avaliação pode ser feita por vários tipos de ator social e no âmbito de diversas disciplinas (ou saberes) que compõem o campo das ciências humanas e sociais, assim como das éticas aplicadas e, particularmente, da bioética. Mas todos os atores sociais que estejam envolvidos nesse tipo de avaliação devem ter em devida conta o pressuposto - aparentemente compartilhado por todas essas disciplinas - de que a tecnologia é (ou deveria ser) produto das decisões que 
representam - direta ou indiretamente - uma escolha em princípio coletiva, fundada em escolhas guiadas por uma finalidade (ou objetivo) consoante com a racionalidade (ou razoabilidade). Embora esta não possa mais ser considerada válida universalmente (visto que não haveria mais consenso moral), tal finalidade deveria ser pelo menos compreensível pela coletividade, e - tendo em conta a globalização atual dos riscos inerentes ao progresso tecnológico e biotecnológico - pela humanidade como um todo.

Entendida nesse sentido amplo, a avaliação tecnológica (ou technology assessment) pode ser vista como uma forma ampla e integrada de avaliação, a qual se refere à pesquisa, ao desenvolvimento tecnocientífico e biotecnocientífico envolvidos, assim como à sua incorporação na sociedade considerando critérios técnicos e administrativos de eficácia (respondendo à pergunta:pode funcionar?), de eficiência (vale a pena utilizá-la?) e de efetividade (funciona de fato?) na solução de problemas. Mas devendo também incluir as consequências (ou as probabilidades de determinadas consequências) positivas e negativas sobre os indivíduos, os grupos sociais e a própria comunidade como um todo, sem esquecer os impactos ambientais (como a perigosa redução da biodiversidade e a destruição de inteiras espécies), que podem ser objeto também da avaliação feita pela ética ambiental.

Esse amplo sentido de avaliação da tecnologia é pertinente e justificado porque, ao contrário da ciência antiga (que surge com a episteme grega) e prémoderna (essencialmente simbólica ou logoteórica) a partir do aparecimento, no século XVII, da ciência experimental, do saber-fazer dos engenheiros no século XX e daquele dos nanotecnólogos do século XXI, ciência, técnica e práxis se tornam inseparáveis (ou são cada vez mais percebidas como tal). Pois nesse novo tipo de saber-fazer-agir os pensamentos, os artefatos e as práticas se tornaram cada vez mais inter-relacionados e inseparáveis.

Consequentemente, na avaliação do saber-fazer tecnocientífico e biotecnocientífico foi preciso começar a levar em conta não somente aspectos teóricos (cognitivos, disciplinares, metodológicos e epistemológicos) e técnicos (como a vantagem comparativa e a performatividade dos produtos e dispositivos produzidos) - como mostra a invenção do neologismo tecnociência -, mas também aspectos sociais, éticos e políticos, indicados pelo termo - 
com conotação negativa - tecnocracia, que pode ser objeto de investigação e avaliação bioética. Pode-se, por exemplo, avaliar o tipo de relação pragmática desejável entre meios e fins, seu controle social democrático, levando em conta as possíveis (ou prováveis) consequências positivas ou negativas envolvidas, em termos de bem-estar e qualidade de vida.

Mas tudo isso apresenta uma série de problemas novos, pois "paradoxalmente, os avanços da tecnociência obrigam a comunidade científica e técnica a se confrontar com a questão do Bem e a integrar a dimensão moral", ao passo que, no passado, "esse progresso só pôde se realizar depois de ter colocado tais temas entre parênteses", baseando-se na suposição de que "todo progresso de poder sobre o real deve ser considerado como um bem para o homem" (Cerezuelle, 2001: 436). Assim, um aspecto essencial da avaliação tecnológica torna-se a dimensão moral (ou a moralidade), estudada pela ética e aplicada pela bioética, como veremos a seguir. Voltaremos, portanto, ao problema da moralidade dos avanços tecnológicos, indicados também pelo termo progresso tecnológico, o qual, fundamentado na "crença de que as circunstâncias presentes constituem aperfeiçoamentos das anteriores" (Blackburn, 1997a: 321), se estende também aos tempos futuros.

\section{A questão da moralidade do progresso tecnológico}

A moralidade (entendida como o conjunto de argumentos favoráveis e contrários a determinado comportamento ou ação) do progresso tecnológico e de suas implicações para o bem-estar de indivíduos e populações de humanos pode ser vista como um objeto das éticas aplicadas e da bioética, desde o aparecimento de uma das primeiras manifestações de ética aplicada (ou prática) no pós-guerra. Em 1956, a filósofa católica oxoniana Elizabeth Anscombe, que havia sido colaboradora de Wittgenstein e em 1939 já assinara um documento contra a guerra, se opôs à outorga do título de doutor honoris causa ao presidente norte-americano Harry Truman, por este ter autorizado o uso das armas atômicas contra a população civil de Hiroshima e Nagasaki. Anscombe (1981b) baseou-se no que considerava uma imoralidade intrínseca ao uso das armas atômicas, ou seja, para ela Truman decidiu usar meios que seriam injustificados em qualquer circunstância, independentemente dos fins aduzidos como possível justificativa; em sua visão, tal uso não se justificaria 
nunca (e isso independentemente do fato de o Japão já ter aceitado a derrota e ter se rendido).

Em nossa avaliação, esse exemplo pode ser tido como pertencente à pré-história (ou aos primórdios) da bioética, pois nele se juntam uma prática (o uso de bombas atômicas) para exterminar formas de vida inocentes (a população das duas cidades japonesas) e a avaliação de sua moralidade, considerada pelo menos questionável (e, para Anscombe, condenável).

Desde seu surgimento, a bioética é entendida como um campo interdisciplinar aplicado ao fenômeno da vida, integrando as ciências biológicas (ou ciências da vida), as humanidades e as ciências sociais, e tendo, de acordo com Potter (1971), como finalidade prática a sobrevivência da espécie humana em seu ambiente. Estabelece, portanto, um novo vínculo entre as ditas duas culturas (Snow, 1959) - a científica e a humanista - mantidas metodologicamente separadas desde o positivismo e, sobretudo, a partir do novo espírito científico representado pelo neopositivismo do Círculo de Viena (formado por filósofos, lógicos e físicos), que publicou, em 1929, seu manifesto "Concepção científica do mundo: o Círculo de Viena" (Hahn, Neurath \& Carnap, 2003). Nesse documento, seus signatários - inspirados no Tractatus Logico-Philosophicus (1921), em que Ludwig Wittgenstein reduz o mundo a um conjunto de fatos descritíveis pela linguagem por meio de proposições lógicas que podem ser consideradas verdadeiras ou falsas (Wittgenstein, 1987) ${ }^{11}$ - defendiam a ideia de que somente a ciência baseada em uma demonstração rigorosa de seus enunciados e vinculada aos dados da observação controlada seria legítima. Por isso, só poderiam ser considerados conhecimentos científicos as proposições lógicas e matemáticas coerentes (para que façam sentido) e as proposições empíricas que devem se basear em fatos, submetidas a critérios de verificação para que sejam consideradas como verdadeiras.

Mas para um dos pioneiros da bioética, o já lembrado cancerologista V. R. Potter, a abordagem dos problemas complexos da bioética deveria

${ }^{11}$ Entretanto, como vimos no primeiro ensaio desta coletânea, o autor mudará de posição em suas últimas obras, quando adotará outro método de análise, distinguindo uma gramática superficial e uma gramática profunda e considerando que o significado de uma palavra é, em última instância, seu uso (como, aliás, já havia dito o linguista Saussure), o qual revela - para quem sabe acessar o nível profundo - seu sentido verdadeiro, evitando, portanto, os erros filosóficos contidos na gramática superficial (Lenk \& Skarica, 2005, destaques do original). 
se basear não mais no método dos neopositivistas, mas sim no método da interdisciplinaridade. Neste, cada disciplina envolvida deveria ser tomada em sua especificidade pelas demais disciplinas, ao mesmo tempo considerando, contudo, as condições de possibilidade para um diálogo constante entre elas. Esse diálogo muitas vezes se mostra tenso devido ao conflito moral (e político) envolvido pelo saber-fazer científico, tecnocientífico e biotecnocientífico, e, sobretudo, devido à conflituosidade intrínseca às relações entre atores e grupos sociais (que precede historicamente a conflituosidade específica referente aos conflitos tecnocientíficos e biotecnocientíficos).

Entretanto, tal tensão pode ter também uma origem corporativa, por se estabelecer entre atores pertencentes a âmbitos cognitivos e práticos que defendem suas identidades e interesses de grupo (ou corporação). De fato, a tensão pode ser vista como, antes, uma característica real e constitutiva do próprio ethos, entendido como um campo complexo de interações entre atores sociais com interesses e valores não necessariamente convergentes nem consensuais, como é o caso das sociedades democráticas, pluralistas e seculares atuais. Não devemos, contudo, esquecer que o ethos não é apenas um campo estruturalmente conflituoso, pois pode ser visto também como espaço em que os conflitos morais são, em princípio, resolvíveis mediante a construção de convergências (embora sempre provisórias e revisáveis) que seriam constitutivas de uma ética convergente aplicável tanto à teoria como à práxis (Maliandi, 2010).

Hoje, a conflituosidade pode ser vista como uma característica intrínseca (ou estrutural) à práxis humana no contexto da vigência da tecnociência e da biotecnociência, pois estas envolveriam sempre não somente conhecimentos e técnicas, mas também atores em interação entre si, que podemos identificar de acordo com uma sugestão de Engelhardt Jr. (1996) - como agentes morais e pacientes morais. Mas a conflituosidade não se deve apenas a uma suposta relação disjuntiva entre o saber-fazer dos cientistas e tecnologistas (entendidos como os agentes) e seus pacientes (os possíveis afetados negativamente), mas também aos conflitos simbólicos (e imaginários) internos aos próprios campos de biotecnociência e da bioética.

Tanto no campo das ciências e das tecnologias (por exemplo, entre paradigmas e metodologias concorrentes) como no campo das éticas aplicadas 152 
(por exemplo, entre a ética religiosa e a ética secular, ou entre aqueles que defendem a sacralidade ou a qualidade da vida real) observa-se uma conflituosidade que não se reduz à competitividade. Em realidade, o problema se mostra mais complexo quando se levam em devida conta os vários aspectos dos conflitos de interesses, que podem afetar, de maneira significativa, a prática científica (como mostram os casos de conflitos de interesses nas práticas de pesquisa).

Nesse sentido, a bioética, entendida como caixa de ferramentas analíticas, críticas e normativas, aplicáveis à moralidade das ações humanas, é aplicável na avaliação da prática e dos produtos do saber-fazer de cientistas e tecnólogos, considerando tanto os conflitos quanto sua possível superação, graças às possíveis e desejáveis convergências anticonflituosas que podem ser construídas e negociadas (eventualmente em nome da empatia). Mas, para chegar a tal convergência, a bioética deve saber se distanciar criticamente tanto das atitudes tecnofílicas como das tecnofóbicas, que podem ser vistas como improdutivas quando se trata de enfrentar, de forma crítica, os problemas complexos inerentes ao progresso tecnológico e à sua incorporação por parte da política e da biopolítica.

Chegando a este momento do raciocínio, pode-se perguntar se, em última instância, a bioética não seria uma mera coleção de normas e, em caso positivo, de que tipo de norma se trataria. Afinal, a bioética tem uma dimensão normativa e poderia, portanto, ser confundida com o direito (e o biodireito)!

\section{Bioética, uma coleção de normas?}

A resposta à pergunta sobre a bioética ser uma coleção de normas ou não é sim ou não, e ambas têm suas razões pertinentes e legítimas, como tentaremos mostrar a seguir.

As razões pertinentes dependem do ponto de vista adotado, que pertence a uma linguagem e a uma experiência, as quais indicam alguma forma de saber vigente que, junto com outros saberes, compõe o capital cultural das chamadas sociedades pluralistas contemporâneas. Mas um saber pode ser reconhecido por uma sociedade como saber especializado. Por exemplo: pode ser reconhecido como um saber científico compartilhado pelos pares, 
considerados especialistas neste tipo de saber. Mas pode ser reconhecido como um saber razoável que faz parte do senso comum, não sendo, portanto, um saber propriamente especializado, embora possa ser considerado um saber pertinente em determinadas circunstâncias. Em outros termos, todos os tipos de saber podem se mostrar pertinentes, desde que sejam organizados em algum sistema simbólico, e ter sua justificativa social, desde que disponham de alguma fonte de legitimidade à qual se referir. Assim estariam dadas as condições de possibilidade para se falar em normatividade, a qual se refere àquilo que deve ser feito, constituindo, portanto, uma fonte de legitimidade para determinada maneira de agir.

Os saberes envolvidos na questão da normatividade podem ser, indiferentemente, a sociologia, o direito, a política, a epistemologia e, também, vários tipos de saber empíricos e pragmáticos do senso comum (como as várias normas profissionais), inclusive crenças ordenadas nos tipos de sistemas de compreensão do mundo representados pelas cosmovisões (Weltanschauungen) e pelas religiões, desde que devidamente fundamentadas e justificadas. De fato, todos esses saberes encontram, em algum momento de seu desenvolvimento, a questão da normatividade, e sobre esta cada saber tem seu olhar, que pode eventualmente compartilhar, dialogando, com outro saber, destacando algum aspecto considerado pertinente por todos os saberes envolvidos, o que constituiria um denominador comum (ou uma convergência).

O enfoque adotado aqui se inscreve no saber indicado pelo termo ética, entendido como um saber teórico e prático que diz respeito aos hábitos e costumes, constitutivos do ethos, e à sua tematização. Esta inclui certamente a questão da normatividade. Ou seja, aqui adotamos o ponto de vista daquela que é conhecida como bioética secular e laica, a qual parte do único pressuposto - em princípio renovável, se for o caso - de que o animal moral, enquanto tal, representado pelo Homo sapiens sapiens, não segue nenhum desígnio preestabelecido, por ser essencialmente - como já defendera Kant na Crítica da Razão Prática - um sujeito de dever, mas também um sujeito da liberdade (Kant, 2003). Por isso, de acordo com uma sugestão de Giorgio Agamben (2001: 39), 
[o] fato do qual deve partir qualquer discurso sobre a ética é que o homem não é, nem há de ser ou realizar alguma essência, alguma vocação histórica ou espiritual, algum destino biológico; (...) somente assim algo como uma ética pode existir, pois [se] o homem fosse ou tivesse de ser esta ou aquela substância, este ou aquele destino, não haveria nenhuma existência ética possível - haveria apenas tarefas a realizar.

Afinal, o Homo sapiens tem a liberdade, que pode exercer ou não, e é limitado tão somente pelas condições de possibilidade.

Feitas essas considerações problemáticas ao conceito de normatividade em geral, podemos enfrentar, agora, a questão específica do papel da normatividade em bioética.

\section{A normatividade em bioética}

Como vimos no item anterior, a bioética pode ser considerada, em um primeiro sentido afirmativo, como uma coleção de normas se entre suas ferramentas pertinentes e legítimas houver algum tipo de construção simbólica (ou imaginário-simbólica, se considerarmos uma aliança possível entre razão e sensibilidade) que possa ser considerado uma norma e se a questão das normas for um de seus objetos de estudo pertinentes.

A pergunta que surge, portanto, é: a bioética é normativa? E a resposta pode ser afirmativa, pois a bioética tem certamente a ver, embora de forma peculiar, com a normatividade (mas distinta, por exemplo, das normatividades do direito e do biodireito, assim como daquela da biossegurança), a qual implica atos de prescrever e proscrever determinadas formas de comportamento. Dizer o que deve ou não ser feito em determinada situação pressupõe uma aprovação ou reprovação de tipo moral (que pode inclusive ter implicações políticas e biopolíticas).

Mas a pergunta pode encerrar um segundo sentido, pois a bioética, além de ter a ver com a normatividade, pode utilizar as ferramentas normativas como uma coleção, organizada e estruturada de tal forma que seus conteúdos (ou sua função social) sejam, mutatis mutandis, como aqueles do direito (ou da religião), como bem mostram as crescentes colaborações de tipo interdisciplinar sobre os problemas bioéticos, biopolíticos e de biodireito. 
Portanto, o aspecto mais importante, neste segundo sentido, é que a questão da normatividade teria a ver com uma "coleção" de normas que, com um olhar desencantado (ou imparcial), interpretaria as normas como impostas ao sujeito moral (que é também cidadão e crente), por assim dizer "de fora" da competência moral "autônoma" dos próprios agentes morais. As normas podem, assim, adquirir um caráter heterônomo, o que certamente constitui um sério problema da questão da normatividade, sobretudo quando forem considerados os vínculos - indicados pela ética contemporânea - entre liberdade e responsabilidade do agente moral. Pois um agente moral só pode ser responsabilizado por suas ações se a decisão que o levou a agir de determinada maneira for a consequência do exercício de sua liberdade em suas decisões, e não de uma imposição externa.

A outra resposta é negativa: a bioética não é uma mera coleção de normas, e isso se houver pelo menos uma distinção possível entre conteúdos, ferramentas e procedimentos da bioética, por um lado, e aqueles, por exemplo, da biossegurança ou do direito (ou biodireito), ${ }^{12}$ por outro. Ou seja, se a reação às normas e à normatividade for significativamente diferente no caso da bioética e naquele, por exemplo, do biodireito e da biossegurança, e se tal diferença puder ser considerada pertinente e legítima (o que seria mostrado pelas diferentes atividades dos especialistas em cada área).

Entretanto, e sem querer aprofundar as possíveis relações entre bioética e biodireito, pode-se pelo menos sugerir (como pista a ser explorada melhor) que tais relações são possíveis, desde que cada forma de saber mantenha sua especificidade (ou autonomia disciplinar) nos eventuais conúbios interdisciplinares que possam vir a existir na abordagem de casos concretos. Em outros termos, é epistemologicamente correto considerar que a interdisciplinaridade autêntica seja aquela que se constrói entre disciplinas constituídas em uma relação de parceria, capazes de ter em devida conta tanto as diferenças de linguagem e conceituais quanto as divergências nas orientações, sem tentar subsumir um saber ao outro, embora isso não implique necessariamente a ausência da forma de conflituosidade simbólica

\footnotetext{
${ }^{12} \mathrm{O}$ biodireito é entendido aqui como aquela forma de saber jurídico que "designa a reflexão e atividade jurídicas e legislativas relativas às chamadas questões de bioética [e] articula-se [às] duas grandes tradições do direito anglo-saxônico e continental-europeu” (Romeo-Casabona, 2001: 112).
} 
representada, por exemplo, pela logomaquia (ou batalha de palavras) que muitas vezes se dá também nas discussões acadêmicas. Em realidade, haveria, nesse caso, tanto uma divergência quanto uma convergência entre tais saberes, quando aplicados ao mesmo tipo de objeto, os quais deveriam, portanto, encontrar uma relação de tipo empático para se entender.

Há ainda outra dimensão da bioética, mais ou menos relevante de acordo com as contingências de um conflito: a dimensão da proteção, que deve ser considerada quando se apresentam condições iniciais significativamente diferentes entre conflitantes, as quais impedem um deles de participar ativamente na solução do conflito, isto é, de exercer uma capacidade significativamente comparável às demais em campo. Nesses casos - que podemos qualificar como de desamparo -, a bioética pode legitimamente lançar mão de medidas protetoras de tipo substantivo e compensatório, fazendo referência, inclusive, ao princípio de justiça entendida como equidade, que permita corrigir a injustiça e restabelecer as condições necessárias para se obter alguma forma de consenso entre desiguais.

A questão da normatividade remete também à identidade e à qualidade das normas em jogo, as quais podem ser distintas em duas grandes categorias: aquelas que pretendem ter um valor absoluto e válido independentemente do contexto ou das circunstâncias, e aquelas que, ao contrário, não pretendem ter tal valor absoluto, devendo, portanto, ser vistas como normas válidas prima facie, como veremos a seguir.

\section{A bioética e as 'éticas da vida'}

Existem, historicamente, duas grandes vertentes opostas de bioética: a bioética da sacralidade da vida (humana), segundo a qual a vida humana é inviolável em qualquer circunstância, e a bioética da qualidade da vida, que, ao contrário, afirma que o valor central é o bem-estar humano e que o critério correto das escolhas morais é a escolha autônoma feita por um agente moral cognitiva e moralmente competente. A primeira fundamenta-se em normas que pretendem ter valor absoluto e eterno - como o princípio da sacralidade da vida, que, por definição, tem sempre uma prioridade, dita "lexical" (ou "léxica"), sobre qualquer outro princípio e em qualquer contexto ou contingência, por 
ser considerado capaz de ordenar e subsumir os demais princípios nos casos de conflito entre os princípios envolvidos em uma disputa moral. A segunda baseia-se em normas historicamente contextualizadas e não absolutas. $\mathrm{Ou}$, se preferirmos: a primeira implica normas válidas, consideradas necessárias, e a segunda normas válidas, mas nem sempre (Mori, 1994).

Tal distinção remete ao que o bioeticista Maurizio Mori chamou de "bioética da sacralidade da vida" e "bioética da qualidade de vida", distinção que se apoia tanto na etimologia das palavras que compõem o neologismo bioethics (bíos, ethos) como em características, reais ou supostas, do ethos vigente nas sociedades atuais - caracterizado, para alguns, por normas universais e absolutas e eternas, ainda válidas em todas as circunstâncias, e, para outros, por normas processuais e evolutivas.

As duas bioéticas são vistas como antitéticas por uma questão, sobretudo, de lógica, visto que não haveria mediação lógica possível entre um absoluto e um não absoluto. Entretanto, vale ressaltar aqui que ambas as bioéticas compartem pelo menos um denominador comum: o termo vida, que remete à etimologia do termo grego bíos, que para a filosofia aristotélica se referia à vida tipicamente humana de inter-relação, que incluía a qualidade de sua práxis, a vida moral e política, constitutivos de uma segunda natureza humana, distinta da vida meramente biológica, chamada zoé..$^{13}$

Tal distinção entre bíos e zoé, feita por Aristóteles, tem se tornado, ao longo do tempo, objeto de novas interpretações. Entre as várias releituras contemporâneas da Política de Aristóteles destacam-se os estudos de Michel Foucault sobre biopolítica e biopoder e aqueles de Giorgio Agamben sobre vida nua, Homo sacer e estado de exceção, pois graças a tais releituras fica patente que a distinção entre bíos e zoé tem se tornado cada vez menos clara ao longo do tempo.

${ }^{13}$ Como escreveu Aristóteles na Política (1278), "O viver segundo o bem é o fim supremo seja em comum para todos os homens, seja para cada um separadamente. Estes, porém, unem-se e mantêm a comunidade política até mesmo tendo em vista o simples viver, porque existe provavelmente uma certa porção de bem até mesmo no mero fato de viver (katà to zen auto mónon); se não há um excesso de dificuldades quanto ao modo de viver (katà ton bíon), é evidente que a maior parte dos homens suporta muitos sofrimentos e se apega à vida (zoé), como se nela houvesse uma espécie de serenidade (eueméria, belo dia) e uma doçura natural. Mas não é apenas para viver juntos, mas sim para bem viver juntos que se fez o Estado" (apud Carvalho, 2011). 
De acordo com o que escreveu Foucault (1976: 188), "Por milênios, o homem permaneceu o que foi para Aristóteles: um animal vivente e, além disso, capaz de existência política; o homem moderno é um animal em cuja política está em questão a sua vida de ser vivente". Ou seja, para Foucault (2004b) a relação entre bíos e zoé seria de fato uma espécie de anexação (ou subsunção) desta (zoé) à primeira (bíos), e isso se manifestaria naquela forma de política que o autor chamou de biopolítica.

Para Agamben, por sua vez, haveria, atualmente, não tanto uma subsunção, mas uma separação "misteriosa" e problemática entre bíos e zoé, pois

Em nossa cultura, o humano sempre foi pensado como articulação e conjunção de um corpo e uma alma, de um vivente e um logos, de um elemento natural (ou animal) e um elemento sobrenatural, social ou divino. Devemos, ao contrário, aprender a pensar o homem como o que resulta da separação entre tais elementos e examinar [o] mistério prático e político dessa separação. (Agamben, 2007: 30-31)

Com base nessas reinterpretações da relação entre bíos e zoé, pode-se ver que a relação entre os dois sentidos do conceito "vida" não é clara, pois esta pode ser vista como uma disjunção (no caso de Agamben), uma inclusão (como na subsunção apontada por Foucault) ou uma parcial sobreposição (como era, em parte, em Aristóteles). E isso pode ter consequências importantes tanto em nível microético (ou das inter-relações entre agentes e pacientes morais) como em nível macroético, se pensarmos na relevância crescente das questões ecológicas, da sociedade de risco estrutural e das possibilidades de destruição da própria vida como um todo no mundo.

$\mathrm{Na}$ atual condição de complexificação da práxis humana e de seus efeitos globais e de longo prazo sobre o fenômeno vida, a distinção entre a simples vida (zoé) e a vida social e política (bíos) se torna muito mais difícil, por não sabermos mais muito bem a que tipo de realidade diferente referir cada termo, porque a referência aos princípios antagônicos da sacralidade e da qualidade torna-se cada vez menos clara. Entretanto, de acordo com os estudos de Agamben, o próprio conceito de sacralidade deveria ser repensado em sua problematicidade ou ambiguidade na atualidade, pois tanto etimologicamente como historicamente, o ser sagrado pode ser tanto o intocável como o eliminável. Como escreve enfaticamente esse autor, 
[a] sacralidade da vida, que se desejaria hoje fazer valer contra o poder soberano como um direito humano em todos os sentidos fundamental, exprime, ao contrário, em sua origem, justamente a sujeição da vida a um poder de morte, a sua irreparável exposição na relação de abandono. (Agamben, 2002: 91)

Essa é a principal razão pela qual se deve enfrentar o desafio de pensar atualmente a bioética secular e laica como um tipo de saber-fazer constituído por uma pluralidade de concepções bioéticas que podem entrar em conflito, como no caso aqui abordado da ética da sacralidade da vida versus ética da qualidade da vida. Isso não significa que necessariamente se deva pensar em várias bioéticas com características identitárias diferentes e diferenças substantivas além das discursivas. É também possível que elas saibam dialogar empaticamente, isto é, procurando uma sintonia de cada uma com a diferença da outra, incluindo tanto a vertente baseada em alguma nova versão do princípio da sacralidade da vida como aquela baseada no princípio da qualidade de vida, assim como vertentes que fazem referência a alguma articulação entre aquelas duas. Isso se tornaria possível mediante a referência, por exemplo, à ambivalência do conceito vida na vigência da biopolítica, como foi pensada com base nos trabalhos de Foucault e Agamben.

Mas tudo isso nos devolve à questão da normatividade.

\section{Voltando à questão da normatividade}

Semanticamente, normatividade é a "qualidade ou condição de normativo", e normativo pode ser entendido, em sentido adjetivo, como "relativo a normas, o que serve de norma, estabelece normas (...); determina o que é correto" (Houaiss \& Villar, 2001: 2.027). Ou seja, normas são modelos (ou paradigmas) de comportamento que, se não forem adotados, implicam alguma forma de censura por parte de quem não as adota como membro do grupo ao qual pertence (ou pretende pertencer).

Há vários tipos de normas, desde aquelas referentes ao modo de produção de objetos - como as normas da International Organization for Standardization (ISO) -, chamadas normas técnicas, que têm a ver com a qualidade de um produto julgada por algum avaliador (que pode ser também o próprio consumidor), até aquelas referentes à vida religiosa (e aplicadas no interior de determi- 
nada comunidade religiosa), passando pelas normas sociais, jurídicas e políticas vigentes em determinada sociedade. Aqui o que nos interessa são, principalmente, as normas morais, pois é da existência delas que depende a nossa possibilidade de falar, com propriedade, de normatividade em bioética (laica ou não).

Em bioética, a normatividade tem a ver com a forma de moralidade vigente ou desejada, e pode ser situada em dois níveis: um interno e outro externo.

Interno porque as normas implicadas nos juízos morais têm a ver com a participação do sujeito, denominado agente moral por ser a causa constatável (ou autor) do ato ao qual a bioética aplica suas ferramentas normativas. Em outros termos, a normatividade interna só faz sentido na presença (e atuação) de um agente moral, instado, por uma decisão própria (baseada kantianamente em sua competência autônoma e boa vontade), a agir de forma a - essencialmente - não prejudicar terceiros, isto é, para que sua ação não provoque danos e sofrimentos evitáveis aos outros.

As fontes dessa interdição podem ser de vários tipos. Além da tradicional e milenar regra de ouro (não faça ao outro o que você não quer que seja feito a você) e do imperativo categórico da moral kantiana apresentada na Fundamentação da Metafísica dos Costumes (age de acordo com uma máxima tal que possas querer, ao mesmo tempo, que ela se torne uma lei universal), há a variante do prescritivismo universal como aquele de Hare (1998), segundo o qual os juízos morais são guias para a ação e constituem normas impostas que podem ser interiorizadas ou não, até formas de emotivismo participante. Nos termos deste último, o comportamento moral se enraíza na natureza afetiva típica da espécie humana e permite "explicar não somente por que as regras éticas nos motivam, mas por que têm uma sobrevivência cultural muito forte, visto que existem provas epidemiológicas sobre a maior capacidade de sobrevida cultural daquilo que é sustentado por uma base afetiva e emotiva" (Lecaldano, 2006: 94). Mas tais normas podem diferir substancialmente das convenções sociais e das normas estabelecidas por alguma autoridade externa que as estabelece, problema que remete à questão da autonomia e da heteronímia do agente moral (que não abordaremos diretamente aqui).

Chegando a este ponto, alguém poderia pensar que o nível interno da normatividade implique também - além de não prejudicar o outro - agir 
de tal forma a favorecê-lo (de algum modo), como pretendem os autores que consideram a bioética como uma ética do amor (Macer, 1998) ou uma ética da compaixão (Siqueira-Batista \& Schramm, 2009). Entretanto, aqui não entraremos no mérito dessas possibilidades, pois se trata de questão delicada que tem a ver seja com a dimensão protetora da bioética (que consideramos justificada em determinados casos relacionados a sujeitos ditos vulneráveis, mas de fato vulnerados), seja com aquela, que pode ser injustificada, e que desde Foucault chamamos de biopolítica (Schramm, 2008).

Existe também uma normatividade externa, que pressupõe aquilo que Ricardo Maliandi denomina a priori de conflituosidade, a qual constituiria "a base tanto para a fundamentação como para a elaboração de um paradigma de aplicabilidade no seio de uma ética convergente" (Maliandi, 2006: 212, destaque do original). Isso quer dizer, em primeiro lugar, que a conflituosidade é um dado estrutural empiricamente constatável. Em segundo lugar, que a conflituosidade diz respeito às próprias ferramentas normativas para resolver os conflitos constatados, ou seja, ela não é apenas um fato constatável, mas também uma característica dos próprios instrumentos com os quais resolvê-los: os próprios princípios morais e seus sistemas valorativos a partir dos quais estabelecer as normas necessárias à solução dos conflitos se mostram conflituosos. No caso da normatividade externa lidamos com uma pluralidade concreta de conflitos, resultante de uma "pluralidade insuperável das concepções morais acatadas pelos seres humanos" (Lecaldano, 2006: 80) e uma pluralidade de ferramentas às quais recorrer para resolvê-los.

Em outros termos, tal situação implica, para a bioética (considerada uma ética aplicada), a busca de soluções efetivas dos conflitos, e isso se referindo tanto às normas situacionais (que podem ser negociadas) quanto aos próprios princípios que as fundamentam, visto que "as teorias de ética normativa podem ser consideradas tentativas de mostrar princípios que sirvam de apoio às normas concretas (ou situacionais)" (Maliandi, 2006: 207).

Assim, a normatividade em bioética, em primeiro lugar, se refere à aplicabilidade das normas nas situações concretas de conflituosidade (que é sua função prática); em segundo, é "uma questão estudada (ou pelo menos estudável) pela ética normativa" (Maliandi, 2006: 199). Em suma, há uma 
relação entre normatividade e aplicabilidade, e, dentro desta, entre normas concretas e princípios morais que as legitimam (ou pretendem legitimar).

\section{Uma Possível Relação Empática entre Bioética e Biossegurança}

Se a bioética é uma ética aplicada que apresenta, além de uma dimensão descritiva, uma dimensão normativa, o principal problema a ser elucidado para uma eventual parceria interdisciplinar (ou transdisciplinar) com outros saberes (como a biossegurança aqui apresentada, ou o biodireito) está em estabelecer o tipo de relação existente entre fundamentos da normatividade (que podem ser de tipo deontológico, teleológico ou misto), a normatividade decorrente e sua aplicabilidade nos saberes envolvidos.

Trata-se de um problema complexo, mas que poderia (de acordo com a preocupação de reduzir a complexidade para que seja possível atuar) ser encarado considerando seriamente que: a aplicabilidade pressupõe a normatividade, a qual, por sua vez, deve se fundamentar em princípios ou valores que permitam, em retorno, a aplicação de normas que permitam, por sua vez, evitar os danos e sofrimentos evitáveis a terceiros. Mas isso pressupõe considerar o a priori da conflituosidade - logo, a necessidade de considerar tal a priori principiológico como condição para que se possa falar pertinentemente tanto de aplicabilidade como de normatividade. Dito diversamente, a normatividade em bioética é algo que se situa entre os princípios a serem buscados e a aplicabilidade de normas fundamentadas em tais princípios. Ou, como escreve Maliandi (2006: 202), "[a] ética aplicada, diferentemente da normativa, não busca nem questiona fundamentos, porque necessariamente os pressupõe", e "[a] ética normativa ascende das situações aos princípios, ao passo que a ética aplicada descende dos princípios às situações".

A questão merece a devida atenção por parte dos bioeticistas laicos que não podem sustentar seu ponto de vista por fundamentos baseados em finalismos supostamente intrínsecos da natureza (de fato derrubados pelo paradigma evolutivo de Darwin) e pretendem orientar a práxis humana, pois, como já visto aqui, de acordo com Agamben (2001: 39), se o homem tivesse uma "substância" ou um "destino" preestabelecido, uma "existência ética" seria praticamente impossível, e haveria apenas "tarefas a realizar". 
Voltando ao objeto principal deste ensaio, nesse quadro complexo e conflituoso parece correto pensar que bioética e biossegurança devam se ocupar do mesmo tipo de problema com ferramentas compartidas: a avaliação tecnológica, a percepção dos riscos envolvidos e a ponderação entre probabilidade de riscos e de benefícios esperados. Entretanto, compartilhar problemas não implica necessariamente que os mesmos problemas sejam abordados da mesma forma por disciplinas diferentes, caso contrário não haveria de fato interdisciplinaridade, mas apenas sobreposição e repetição (ou anexação). Não podemos esquecer o que distingue e vincula bioética e biossegurança, pelo menos se aceitarmos a tese aqui defendida: a existência de um dos dois tipos de saber, constituída por aquele lugar que separa e une dois campos e que - dessa maneira - faz com que entrem em contato entre si, mas mantendo também sua identidade própria. Por isso, a relação entre bioética e biotecnociência pode ser vista como complexa, mas também como uma relação de tipo empático, uma vez que, nela, as diferenças dialogam e se complementam.

Sem essa preocupação metodológica de distinguir sem separar e juntar sem confundir, que consiste em perguntarmos o que distingue e vincula bioética e biossegurança - e que indicamos pela dupla conjunção e/ou -, não poderíamos falar corretamente em interface e, provavelmente, não saberíamos responder satisfatoriamente à pergunta "como evitar riscos?".

Entre os especialistas que defendem uma concepção global da bioética, a começar pelo próprio Potter (1988, 1998; Campbell, 1999), costuma-se afirmar que uma das contribuições da bioética está no fato de esta ter ampliado o âmbito tradicional das preocupações éticas, de modo a incluir não só os antigos e novos problemas e dilemas da ética médica (já abordados a partir de Hipócrates), mas também a totalidade dos problemas e dilemas morais relativos a toda intervenção humana na biosfera (Sakamoto, 1999; Tangwa, 1999).

Por sua vez, a biossegurança pode construir estratégias de proteção contra os riscos da biotecnociência, calculando e ponderando probabilidades de risco, tentando prevenir (quando isso for possível com os dados disponíveis), reduzir ou compensar eventuais danos (diretos ou indiretos) às populações humanas, ocasionados pela manipulação indevida de organismos vivos e do ambiente natural. 
A necessidade de considerar uma interface entre bioética e biossegurança se torna mais clara quando pensamos que a biossegurança é essencialmente uma técnica precautória de controle e gestão não necessariamente eficaz e nisso a biossegurança se assemelha à bioética -, visto que deve lidar com muitas variáveis desconhecidas e incontroláveis, e que o contexto real de sua atuação é cada vez mais aquele do risco estrutural em situação de incerteza, em que - como tentamos mostrar - o próprio conceito de risco parece se confundir com os de dano e perigo.

Assim, a biossegurança atuaria em um contexto no qual a regulação e o controle eficazes seriam cada vez mais objetivos problemáticos e, provavelmente, dificilmente alcançáveis. Mas isso também tem seus riscos, que vão desde a ineficácia até a vigência de um estado de exceção geral (como pretende Agamben), que poderia ser visto como o gestor das emoções do imaginário social ao preço de medidas liberticidas, se estas forem consideradas, hobbesianamente, como a única solução para controlar a sociedade de risco por aqueles que têm o poder (ou biopoder) requerido e supostamente legítimo, ou por ser em princípio protetor (ou paternalista).

E é aqui que entraria a bioética para legitimar, ou deslegitimar, perante a sociedade, os riscos que valeria a pena correr, ou não, tendo em conta tanto os objetivos pragmáticos legítimos da biotecnociência quanto a eficácia da biossegurança em prever, controlar e evitar a ocorrência dos riscos. Bioética e biossegurança podem colaborar para construir pelo menos pontos de convergência (ou interfaces) acerca de como encarar, de forma racional e, até onde for possível, imparcial, os riscos que uma sociedade democrática (e razoável) decidir correr para alcançar os benefícios potenciais desejados, minimizando os riscos diante do fenômeno complexo e polêmico chamado biotecnociência. 


\section{Referências}

AGAMBEN, G. Quel che Resta di Auschwitz: l'archivio e il testimone - Homo sacer.Torino: Bollati-Boringhieri, 1998. v. 3.

AGAMBEN, G. La Comunità che Viene. Torino: Bollati Boringhieri, 200 I.

AGAMBEN, G. Homo sacer: o poder soberano e a vida nua I. Belo Horizonte: Editora UFMG, 2002.

AGAMBEN, G. Estado de Exceção. São Paulo: Boitempo, 2004.

AGAMBEN, G. Che Cos'è un Dispositivo? Roma: Nottetempo, 2006.

AGAMBEN, G. L'Ouvert: de l' homme et de l'animal. Paris: Rivages, 2007.

ANDERS, G. Die Antiquiertheit des Menschen. München: Oscar Beck Verlag, 1980.

ANGELL, M. A Verdade sobre Laboratórios Farmacêuticos. Rio de Janeiro: Record, 2007.

ANSCOMBE, G. E. M. Modern moral philosophy [1958]. In:ANSCOMBE, G. E. M. Ethics, Religion and Politics. Oxford: Oxford University Press, I98Ia.

ANSCOMBE, G. E. M. Mr.Truman's degree. In:ANSCOMBE, G. E. M. Ethics, Religion and Politics. Minneapolis: University of Minnesota Press, I $98 \mathrm{Ib}$. (Collected Philosophical Papers, 3)

APEL, K.-O.The problem of a Macroethik of responsibility to the future in the crisis of technological civilization: on attempt to come to terms with Hans Jona's principle of responsibility. Trad.Wilson Brown. Man and World, 20: 3-40, 1987.

APEL, K.-O. Transformação da Filosofia I: filosofia analítica, semiótica, hermenêutica. São Paulo: Loyola, 2000.

AUSTIN, J. L. How to Do Things with Words. Oxford: Clarendon Press, 1962.

BALISTRERI, M. Precauzione, principio di. In: LECALDANO, E. Dizionario di Bioetica. Roma: Laterza, 2002.

BAUMAN, Z. Miedo Líquido: la sociedad contemporánea y sus temores. Buenos Aires: Paidós, 2007.

BAZZICALUPO, L. Biopolitica: una mappa concettuale. Roma: Carocci, 2010.

BECK, U. Risikogesellschaft. Auf dem Weg in eine andere Moderne. Frankfurt: Suhrkamp, 1986.

BECK, U. Risque et société. In: MESURE, S. \& SAVIDAN, P. (Dirs.). Le Dictionnaire des Sciences Humaines. Paris: PUF, 2006.

BECK, U. Weltrisikogesellschaft:Auf der Suche nach der verlorenen Sicherheit. Frankfurt am Main: Suhrkamp, 2007. 
BECK, U. Penser la société du risque global. Le Monde. Paris, 24 out. 2008. Disponível em: <www.lemonde.fr/opinion/article/2008/I0/23/penser-la-société-du-risque-global-parulrich-beck_III025I_3232.html>.Acesso em: 22 nov. 2013.

BENOIST, J. Éléments de Philosophie Réaliste. Paris:Vrin, 20I la.

BENOIST, J. Concepts : introduction à l'analyse. Paris: Du Cerf, $20 \mathrm{I} \mathrm{Ib.}$

BENTHAM, J. An Introduction to the Principles of Morals and Legislation. Mineola, New York: Dover, 2007.

BERLINGUER, G. Etica della Salute. Milano: II Saggiatore, 1994.

BERLINGUER, G. \& GARRAFA,V. O Mercado Humano: estudo bioético da compra e venda de partes do corpo. Brasília: Editora UnB, 1996.

BERNSTEIN, R. The Pragmatic Turn. Cambridge: Polity Press, 2010.

BLACKBURN, S.Atos de fala. In: BLACKBURN, S. Dicionário Oxford de Filosofia. Rio de Janeiro: Jorge Zahar, 1997a.

BLACKBURN, S. Metaética. In: BLACKBURN, S. Dicionário Oxford de Filosofia. Rio de Janeiro: Jorge Zahar, 1997b.

BLACKBURN, S. Pragmatismo. In: BLACKBURN, S. Dicionário Oxford de Filosofia. Rio de Janeiro: Jorge Zahar, 1997c.

BLACKBURN, S. Filosofia analítica. In: BLACKBURN, S. Dicionário Oxford de Filosofia. Rio de Janeiro: Jorge Zahar, 1997d.

BLACKBURN, S. Dilemas morais. In: BLACKBURN, S. Dicionário Oxford de Filosofia. Rio de Janeiro: Jorge Zahar, I997e.

BLOCH, O. \& VON WARTBURG,W. Dictionnaire Étymologique de la Langue Française. 5. ed. Paris: Presses Universitaires de France, 1968.

BOFF, L. Ética da Vida: a nova centralidade. Rio de Janeiro: Record, 2009.

BRASIL. Presidência da República. Casa Civil. Lei n. I I.I05, de 24 mar. 2005. Estabelece normas de segurança e mecanismos de fiscalização de atividades que envolvam organismos geneticamente modificados - OGM e seus derivados, cria o Conselho Nacional de Biossegurança - CNBS, reestrutura a Comissão Técnica Nacional de Biossegurança - CTNBio, dispõe sobre a Política Nacional de Biossegurança - PNB. Diário Oficial da União, Brasília, 2005. Disponível em: <www.planalto.gov.br/ccivil_03/_ ato2004-2006/2005/lei/l I I I05.htm>.Acesso em: 27 out. 2013.

BRENTANO, F. Vom Ursprung Sittlicher Erkenntnis. Leipzig: Duncker \& Humblot, 1889.

BRICET, G.-H. \& VALLONS, B. Faut-il Brûler la Contre-Insurrection? Paris: Choiseul, 2010.

BRINK, D. O. Réalisme moral. In: CANTO-SPERBER, M. (Dir.). Dictionnaire d'Éthique et de Philosophie Morale. Paris: Presses Universitaires de France, 1997.

BRISSON, L. \& PRADEAU, J. F. Vocabulário de Platão. São Paulo: Martins Fontes, 2010. 
CAEYMAEX, F. Risquer, gérer, sécuriser: techniques politiques de la modernité? In: KERMISCH, C. \& HOTTOIS, G. (Éds.). Techniques et Philosophies des Risques. Paris:Vrin, 2007.

CALABRÒ, D. Le svolte di um pensiero vivente. In: CALABRÒ, D.; GORIA, G. \& ESPOSITO, R. Comunità e Biopolitica. Milano: Mimesis, 2012.

CALCATERRA, R. M. Introduction. In: CALCATERRA, R. M. (Ed.). New Perspectives on Pragmatism and Analytic Philosophy.Amsterdam: Rodopi, $201 \mathrm{I}$.

CAMPBELL,A.V. Presidential address: global bioethics - dream or nightmare? Bioethics, 13(3/4): 183-190, 1999.

CARNAP, R. Überwindung der Metaphysik durch logische Analyse der Sprache. Erkenntnis, 2: $219-241,1932$.

CARVALHO, J.A distinção entre zoé e bíos em Aristóteles, 20I I. Disponível em: <www.webartigos.com/artigos/a-distincao-entre-zoe-e-bios-emaristoteles/6386 I/\#ixzz26r4e0aLI>.Acesso em: I8 maio 2014.

CASTIEL, L. D. \& DIAZ, C.A. D. A Saúde Persecutória: os limites da responsabilidade. Rio de Janeiro: Editora Fiocruz, 2007.

CASTRO, E. Dispositivo. In: CASTRO, E. Vocabulário de Foucault. Belo Horizonte:Autêntica, 2009.

CATELLIN, S. Sérendipité: du conte au concept. Paris: Seuil, 2014.

CEREZUELLE, D. Evaluation technologique: technology assessment. In: HOTTOIS, G. \& MISSA, J.-N. (Éds.). Nouvelle Encyclopédie de Bioéthique. Bruxelles: De Boek, $200 \mathrm{I}$.

CIOTTI,A. Fortuna. In: MELCHIORRE, V. (Dir.). Enciclopedia Filosofica. v. 5. Milano: Bompiani, 2006.

COPP, D. Introduction: metaethics and normative ethics. In: COPP, D. (Ed.). The Oxford Handbook of Ethical Theory. Oxford: Oxford University Press, 2006.

CORBIN,A. Sensibilités (Histoire des). In: MESURE, S. \& SAVIDAN, P. (Dirs.). Le Dictionnaire des Sciences Humaines. Paris: PUF, 2006.

CORMIER, H. Editorial foreword. In: CALCATERRA, R. M. (Ed.). New Perspectives on Pragmatism and Analytic Philosophy.Amsterdam: Rodopi, $201 \mathrm{I}$.

CREMASCHI, S. L'etica del Novecento. Roma: Carocci, 2005.

CREMASCHI, S. Conflitto di interessi. In: MELCHIORRE,V. (Dir.). Enciclopedia Filosofica. v. 3. Milano: Bompiani, 2006.

D'AGOSTINI, F. Analitici e Continentali: guida alla filosofia degli ultimi trent'anni. Milano: Raffaello Cortina, 1997.

DA RE,A. Metaetica. In: MELCHIORRE,V. (Dir.). Enciclopedia Filosofica. v. 8. Milano: Bompiani, 2006.

DEPRAZ, N.Autrui. In: CANTO-SPERBER, M. (Dir.). Dictionnaire d'Éthique et de Philosophie Morale. Paris: Presses Universitaires de France, 1997. 
DICIONÁRIO REX. Site. Disponível em: <http://senhordaspalavras.com.br/significado/ neotenia>.Acesso em: 27 out. 2013.

DONDERO, M. G. Pour une approche sémiotique des pratiques éthique. Protée - Revue Internationale des Pratiques Ethiques, 36(2): 5- 10, 2008. Disponível em: <http://hdl.handle. net/2268/65459>.Acesso : 13 set. 2013.

DUPUY, J. P. Petite Métaphysique des Tsunamis. Paris: Seuil, 2005.

DURAND, G. Introdução Geral à Bioética. São Paulo: Loyola, 2003.

ELLUL, J. La Technique ou l'Enjeu du Siècle. Paris: Calmann-Lévy, 1954.

ENGELHARDT JR., H.T. The Foundations of Bioethics. 2. ed. New York, Oxford: Oxford University Press, 1996.

ENGELHARDT JR., H.T.A bioética do risco: enfrentando a finitude humana. In: SCHRAMM, F. R. et al. (Orgs.). Bioética, Riscos e Proteção. Rio de Janeiro: Editora UFRJ, Editora Fiocruz, 2005.

ENGELHARDT JR., H.T. Bioética global: uma introdução ao colapso do consenso. In: ENGELHARDT JR., H.T. (Org.). Bioética Global. São Paulo: Paulinas, União Social Camiliana, Centro Universitário São Camilo, 2012.

ESPOSITO, R. Immunitas: protezione e negazione della vita.Torino: Einaudi, 2002.

ESPOSITO, R. Pensiero Vivente: origine e attualità della filosofia italiana. Torino: Einaudi, 2010.

FONTANILLE, J. Sémiotique et éthique, 2007. Disponível em: <http://revues.unilim.fr/nas/ document.php?id=|795>.Acesso em: 12 nov. 2013.

FOUCAULT, M. La Volonté de Savoir. Paris: Gallimard, 1976.

FOUCAULT, M. Sécurité, Territoire, Populations: cours au Collège de France, 1977-1978. Paris: Gallimard, 2004a.

FOUCAULT, M. Naissance de la Biopolitique: cours au Collège de France, 1978-1979. Paris: Gallimard, 2004b.

GARGANI,A. Rorty. In: MELCHIORRE,V. (Dir.). Enciclopedia Filosofica. v. 8. Milano: Bompiani, 2006.

GEORGETOWN UNIVERSITY MEDICAL CENTER. Site. Disponível em: <http:// clinicalbioethics.georgetown.edu/>.Acesso em: 10 nov. 2013.

GILSON, E. Le Réalisme Méthodique. Paris:Tequi, 1935.

GOBRY, I. Vocabulário Grego da Filosofia. São Paulo: Martins Fontes, 2007.

GODARD, O. Precaution (principe de). In: HOTTOIS, G. \& MISSA, J.-N. (Éds.). Nouvelle Encyclopédie de Bioéthique, 200 I.

GOFFI, J.-Y. Ecologie profonde. In: HOTTOIS, G. \& MISSA, J.-N. (Éds.). Nouvelle Encyclopédie de Bioéthique. Bruxelles: De Boek, 200I.

GROS, F. Michel Foucault. 2. ed. corr. Paris: Presses Universitaires de France, 1998. 
GROS, F. Le Principe Sécurité. Paris: Gallimard, 2012.

GUILLERMIT, L. Emmanuel Kant e a filosofia crítica. In: CHÂTELET, F. (Org.). História da Filosofia. v. 3. De Kant a Husserl. Lisboa: Publicações Dom Quixote, 1995.

HABERMAS, J. Die Zukunft der menschlichen Natur:Auf dem Weg zu einer liberalen Eugenik? Frankfurt am Main: Suhrkamp Verlag, 200I.

HAHN, H.; NEURATH, O. \& CARNAP, R. The scientific conception of the world:The Vienna Circle. In: SCHARF, R. C. \& DUSEK,V. (Eds.). Philosophy of Technology. Malden, Oxford: Blackwell, 2003.

HARE, R. M. Ética: problemas e propostas. São Paulo: Editora Unesp, 1998.

HARRIS, J. Wonderwoman and Superman: the ethics of human biotechnology. Oxford: Oxford University Press, 1992.

HEGENBERG, L. Dicionário de Lógica. São Paulo: EPU, 1995.

HEIDEGGER, M. Ge-stell. Gesamtausgabe. III.Abteilung: Unveröffentlichte Abhandlungen. Band 79 - Bremer und Freiburger Vorträge. Frankfurt am Main:Vittorio Klostermann, 1994.

HOBBES, T. Leviatã ou Matéria: forma e poder de um Estado eclesiástico e civil. São Paulo: Martin Claret, 2002.

HOTTOIS, G. Le Paradigme Bioéthique: une éthique pour la tecnocience. Bruxelles: De BoeckWesmael, 1990.

HOTTOIS, G. Déontologie et éthique médicale. In: HOTTOIS, G. \& MISSA, J.-N. (Éds.). Nouvelle Encyclopédie de Bioéthique. Bruxelles: De Boeck, 200 la.

HOTTOIS, G. Bioéthique. In: HOTTOIS, G. \& MISSA, J.-N. (Éds.). Nouvelle Encyclopédie de Bioéthique. Bruxelles: De Boeck, $200 \mathrm{Ib}$.

HOTTOIS, G. Metodologia bioética. In: HOTTOIS, G. \& MISSA, J.-N. (Eds.). Nova

Enciclopédia da Bioética.Trad. Maria Carvalho. Lisboa: Instituto Piaget, 2003a.

HOTTOIS, G. Bioética. In: HOTTOIS, G. \& MISSA, J.-N. (Eds.). Nova Enciclopédia da Bioética. Trad. Maria Carvalho. Lisboa: Instituto Piaget, $2003 \mathrm{~b}$.

HOTTOIS, G. Pluralismo. In: HOTTOIS, G. \& MISSA, J.-N. (Eds.). Nova Enciclopédia de Bioética. Trad. Maria Carvalho. Lisboa: Instituto Piaget, 2003c.

HOTTOIS, G. Qual é o quadro temporal para pensar nas gerações futuras? Uma abordagem filosófica. In: SCHRAMM, F. R. et al. (Orgs.). Bioética, Riscos e Proteção. Rio de Janeiro: Editora UFRJ, Editora Fiocruz, 2005.

HOUAISS, A. \& VILLAR, M. S. Dicionário Houaiss da Língua Portuguesa. Rio de Janeiro: Objetiva, 200I.

HUME, D. Tratado da Natureza Humana. São Paulo: Editora Unesp, 200 I.

HUSSERL, E. Die Krisis der europäishen Wissenshaften und die transzendentale Phänomenologie. Eine Einleitung in die phänomenologische Philosophie. The Hague: Martinus Nijhoff, 1976. 
JAHR, F. Bio-ethik. Eine Umschau über die ethischen Beziehungen des Menschen zu Tier und Pflanze, Kosmos. Handweiser für Naturfreunde, 24(I): 2-4, 1927.

JONAS, H. Wissenschaft als persönliches Erlebnis. Göttingen:Vandenhoeck u. Ruprecht, 1987.

JONAS, H. Ética, Medicina e Técnica. Lisboa:Veja, Passagens, 1994.

JONAS, H. O Princípio Responsabilidade: ensaio de uma ética para a civilização tecnológica [1979]. Rio de Janeiro: Contraponto, 2006.

JÜNGER, E. L'État Universel (suivi de) La Mobilisation Totale. Paris: Gallimard, 1990.

KANT, I. Crítica da Razão Pura. 2. ed. Lisboa: Fundação Calouste Gulbenkian, 1989.

KANT, I. Crítica da Razão Prática. São Paulo: Martins Fontes, 2003.

KERMISCH, C. Introduction. In: KERMISCH, C. \& HOTTOIS, G. (Éds.). Techniques et Philosophies des Risques. Paris:Vrin, 2007a.

KERMISCH, C. Le citoyen face au risque chez Shrader-Frechette. In: KERMISCH, C. \& HOTTOIS, G. (Éds.). Techniques et Philosophies des Risques. Paris:Vrin, 2007b.

KOTTOW, M. Bioética Ecológica. Bogotá: Ediciones El Bosque, 2009.

LA PROVIDENCE DE L'ÉTAT. Entretien avec François Ewald. Projet, 26I, mar. 2000.

Disponível em: <www.revue-projet.com/?s=Fran\%C3\%A7ois+Ewald\&type=simplesite\&submit. $x=0 \&$ submit. $y=0>$. Acesso em: $3 \mathrm{I}$ ago. $20 \mathrm{I} 3$.

LA RECHERCHE: L'ACTUALITÉ DES SCIENCES. Le dossier du bioterrorisme. Disponível em: <www.larecherche.fr/content/recherche/article?id=|2305>.Acesso em: 07 jun. 2014.

LACAN, J. Écrits. Paris: Seuil, 1966.

LACAN, J. Le Séminaire. Livre XI. Les quatre concepts fondamentaux de la psychanalyse. Paris: Seuil, 1973.

LALANDE, A. Éthique. In: LALANDE, A. Vocabulaire Technique et Critique de la Philosophie. Paris: Presses Universitaires de France, 1972a.

LALANDE,A. Moralité. In: LALANDE, A. Vocabulaire Technique et Critique de la Philosophie. Paris: Presses Universitaires de France, 1972b.

LECALDANO, E. Conoscenza etica. In:VASSALLO, N. (Ed.). Filosofia delle Conoscenze. Torino: Codice Edizioni, 2006.

LENK, H.Wittgenstein y el giro pragmático en la filosofía. In: LENK, H. \& SKARICA, M. Wittgenstein y el Giro Pragmático en la Filosofia. Córdoba: Ediciones del Copista, 2005.

LENK, H. \& SKARICA, M. Wittgenstein y el Giro Pragmático en la Filosofia. Córdoba: Ediciones del Copista, 2005.

LYOTARD, J.-F. La Condition Postmoderne. Paris: Minuit, 1979.

MACCHIAVELLI, N. II Principe e Discorsi. Milano: Feltrinelli, 1960. 
MACER, D. Bioethics is Love of Life: an alternative textbook. Christchurch: Eubios Institute, 1998.

MALIANDI, R. Ética: conceptos y problemas. 3.ed. Buenos Aires: Biblos, 2004.

MALIANDI, R. Ética: dilemas y convergencias. Cuestiones éticas de la identidad, la globalización y la tecnología. Buenos Aires: Editorial Biblos, Ediciones de la UNLa, 2006.

MALIANDI, R. Ética Convergente: fenomenología de la conflictividad. Buenos Aires: Las Cuarentas, 2010.

MALIANDI, R. \& THÜER, O. Teoría y Praxis de los Principios Bioéticos. Buenos Aires: Ediciones de la UNLa, 2008.

MAUTNER, T. Metaética. In: MAUTNER, T. (Dir.). Dicionário de Filosofia. Lisboa: Edições 70, 2010 a.

MAUTNER, T. Moralidade. In: MAUTNER, T. (Dir.). Dicionário de Filosofia. Lisboa: Edições 70, 20IOb.

MAUTNER, T. Realismo crítico. In: MAUTNER, T. (Dir.). Dicionário de Filosofia. Lisboa: Edições 70, 2010c.

MAUTNER, T.Análise. In: MAUTNER, T. (Dir.). Dicionário de Filosofia. Lisboa: Edições 70, 20I0d.

MAUTNER, T. Observador ideal. In: MAUTNER, T. (Dir.). Dicionário de Filosofia. Lisboa: Edições 70, 2010e.

MAUTNER, T. Brentano, Franz. In: MAUTNER, T. (Dir.). Dicionário de Filosofia. Lisboa: Edições 70, 2010 f.

MAUTNER, T. Revolução. In: MAUTNER, T. (Dir.). Dicionário de Filosofia. Lisboa: Edições 70, $20 \mathrm{lOg}$.

MENEZES, E.T. \& SANTOS, T. H. Multidisciplinaridade. In: Dicionário Interativo da Educação Brasileira - EducaBrasil. São Paulo: Midiamix, 2002. Disponível em: <www.educabrasil.com. br/eb/dic/dicionario.asp?id=90>. Acesso em: 31 ago. 2013.

MERLEAU-PONTY, M. Le Visible et I'Invisible. Paris: Gallimard, 1964.

MOENS, W. Biosécurité. In: HOTTOIS, G. \& MISSA, J.-N. (Éds.). Nouvelle Encyclopédie de Bioéthique. Bruxelles: De Boeck, $200 \mathrm{la}$.

MOENS,W. Biorisque. In: HOTTOIS, G. \& MISSA, J.-N. (Éds.). Nouvelle Encyclopédie de Bioéthique. Bruxelles: De Boeck, $200 \mathrm{lb}$.

MOORE, G. E. Principia Ethica. Lisboa: Fundação Calouste Gulbenkian, 1999.

MORALES, J. O.Atención clínica y contexto social. In:TEALDI, J. C. (Dir.). Diccionario Latinoamericano de Bioética. Bogotá: Unesco, Universidad Nacional de Colombia, 2008.

MORI, M.A bioética: sua natureza e história. Humanidades, 34(9): 332-34I, 1994.

MORI, M. A Moralidade do Aborto: sacralidade da vida e o novo papel da mulher. Brasília:

Editora UnB, 1997. 
MORI, M. Bioetica: 10 temi per capire e discutere. Milano: Bruno Mondadori, 2002.

MORI, M. Una 'analisi bioética' dell'attuale disputa sul testamento biologico come estensione del consenso informato. Notizie di Politeia, XXVII(I02): 53-80, 201 I.

MORIN, E. Le Paradigme Perdu: la nature humaine. Paris: Seuil, 1973.

MORIN, E. Introduction à la Pensée Complexe. Paris: ESF, I990.

MUCCHIELLI,A. Dictionnaire des Méthodes Qualitatives en Sciences Humaines. 3. ed. Paris: Armand Colin, 20I Ia.

MUCCHIELLI,A. Complexité [paradigme de la]. In: MUCCHIELLI,A. (Dir.). Dictionnaire des Méthodes Qualitatives en Sciences Humaines. 3. ed. Paris:Armand Colin, 20 I lb.

MUCCHIELLI,A. \& NOY, C. Études des Communications: approches construtivistes. Paris: Armand Colin, 2005.

NAESS, A. Ecology, Community and Lifestyle. Cambridge: Cambridge University Press, 1989.

NAGEL, T. A Última Palavra. Lisboa: Gradiva, 1999.

NEVES, M. C. P. \& LIMA, M. Bioética ou Bioéticas na Evolução das Sociedades. Coimbra: Gráfica de Coimbra, 2005.

NUSSBAUM, M. C. A Fragilidade da Bondade: fortuna e ética na tragédia e na filosofia grega. São Paulo: Martins Fontes, 2009.

OGIEN, R. Réalisme et sciences humaines. In: MESURE, S. \& SAVIDAN, P. (Dirs.). Dictionnaire des Sciences Humaines. Paris: Presses Universitaires de France, 2006.

PALOMBI, F. La Stella e I'Intero: la ricerca di Gian-Carlo Rota tra matematica e fenomenologia. Torino: Bollati Boringhieri, 2003.

PARIENTE-BUTTERLIN, I. Fondements de la Métaphysique des Moeurs. Paris: Ellises, 2000.

PIAGET, J. L'épistémologie des relations interdisciplinaires. In:. L'Interdisciplinarité: problèmes d'enseignement et de recherche dans les universités. Paris: OCDE, 1972. Disponível em: <www.fondationjeanpiaget.ch/fjp/site/bibliographie/index_chapitres_alpha3.php>. Acesso em: 29 out. 2013.

PINSART, M. G. De la precaution à la responsabilité: analyse socio-politique et philosophique des risques tecnocientifiques. In: KERMISCH, C. \& HOTTOIS, G. (Éds.). Techniques et Philosophies des Risques. Paris:Vrin, 2007.

PLATONE. Protagora. In: PLATONE. Tutte le Opere. Milano: Sansoni, 1974.

PORTAL FIOCRUZ. Bioterrorismo. Disponível em: <www.fiocruz.br/biosseguranca/Bis/ infantil/bioterrorismo.htm>.Acesso em: 7 jun. 2014.

POTTER,V. R. Bioethics: bridge to the future. Englewood Cliffs: Prentice Hall, 197I.

POTTER, V. R. Global Bioethics: building on the Leopold legacy. East Lansing: Michigan State University Press, 1988.

POTTER,V. R. Bioética puente, bioética global y bioética profunda. Bioética: Cuadernos del Programa Regional de Bioética, 7: 21-35, 1998. 
PUTNAM, H. O Colapso da Verdade e Outros Ensaios. Aparecida: Ideias \& Letras, 2008.

PUTNAM, H.Autorretrato filosófico. In: MAUTNER, T. (Dir.). Dicionário de Filosofia. Lisboa: Edições 70, 2010.

PUTNAM, R.A. Pragmatisme. In: CANTO-SPERBER, M. (Dir.). Dictionnaire d'Éthique et de Philosophie Morale. Paris: Presses Universitaires de France, 1997.

PYRRHO, M. Nanociência e bioética: novas abordagens éticas para novos paradigmas científicos. Revista Brasileira de Bioética, 4(3-4): 222-235, 2008.

REVEL, J. Dispositif. In: REVEL, J. Dictionnaire Foucault. Paris: Ellipses, 2008.

ROMEO-CASABONA, C. M. Biodroit. In: Nouvelle Encyclopédie de Bioéthique. Bruxelles: De Boeck, 200I.

RORTY, R. The Linguistic Turn: essays in philosophical method. Chicago: University of Chicago Press, 1967.

SAKAMOTO, H. Towards a new 'global bioethics'. Bioethics, 13(3/4): 191-197, 1999.

SALZANO, F. M. Genômica: para onde caminha a humanidade? In: MIR, L. (Org.). Genômica. São Paulo:Atheneu, 2004.

SAUSSURE, F. Cours de Linguistique Générale [1916]. Paris: Payot, 1974.

SCHIAVELLO,A. Realismo morale. In: MARASSI, M. (Coord.). Enciclopedia Filosofica. v. I0. Milano: Bompiani, 2006.

SCHRAMM, F. R. Paradigma biotecnocientífico e paradigma bioético. In: ODA, L. M. (Ed.). Biosafety Transgenic Organisms in Human Health Products. Rio de Janeiro: Fiocruz, 1996.

SCHRAMM, F. R. Eugenia, eugenética e o espectro do eugenismo: considerações atuais sobre biotecnociência e bioética. Bioética, 5(2): 203-220, 1997.

SCHRAMM, F. R. Bioética e biossegurança. In: COSTA, S. I. F.; OSELKA, G. \& GARRAFA,V. (Orgs.). Iniciação à Bioética. Brasília: Conselho Federal de Medicina, 1998.

SCHRAMM, F. R. Genética: um Jano de duas faces? In: GARRAFA, V. \& COSTA, S. I. F. (Orgs.). A Bioética no Século XXI. Brasília: Editora UnB, 2000.

SCHRAMM, F. R.A moralidade da biotecnociência: a bioética da proteção pode dar conta do impacto real e potencial das biotecnologias sobre a vida e/ou a qualidade de vida das pessoas humanas? In: SCHRAMM, F. R. et al. (Orgs.). Bioética, Riscos e Proteção. Rio de Janeiro: Editora UFRJ, Editora Fiocruz, 2005.

SCHRAMM, F. R.A saúde é um direito ou um dever? Prolegômenos a uma autocrítica da saúde pública. Considerações sobre vulnerabilidade, vulneração, proteção, biopolítica e hospitalidade. Revista Brasileira de Bioética, I6(I): I I-23, 2008. Disponível em: <www. revistabioetica.cfm.org.br/index.php/revista_bioetica/article/viewFile/52/55>.Acesso em: 29 out. 2013.

SCHRAMM, F. R. O uso problemático do conceito "vida" em bioética e suas interfaces com a práxis biopolítica e os dispositivos de biopoder. Revista Bioética, I7(3): 377-389, 2009. 
SCHRAMM, F. R. Pensamento complexo e saúde pública. In: HORTALE, V.A. et al. (Orgs.). Pesquisa em Saúde Coletiva: fronteiras, objetos e métodos. Rio de Janeiro: Editora Fiocruz, 2010a.

SCHRAMM, F. R. Bioética, biossegurança e a questão da interface no controle das práticas da biotecnociência: uma introdução. Revista Redbioética/Unesco, I (2): 99-I I0, 20 I 0 b. Disponível em: <www.unesco.org.uy/shs/red-bioetica/es/revista>.Acesso em: 10 out. 2013.

SCHRAMM, F. R. Uma breve genealogia da bioética em companhia de Van Rensselaer Potter. Bioethikos, 5(3): 302-308, $20 \mathrm{II}$.

SCHRAMM, F. R. Questões conceituais e metaéticas da bioética clínica: uma introdução. Bioethikos, 6(2): I25-I32, 2012.

SÈVE, B. La peur comme procédé heuristique et comme instrument de persuasion. In: HOTTOIS, G. (Éd.). Aux Fondements d'une Éthique Contemporaine : H. Jonas et H.T. Engelhardt en perspective. Paris: Librarie Philosophique J.Vrin, 1993.

SHATTUCK, R. Conhecimento Proibido. São Paulo: Companhia das Letras, 1998.

SHRADER-FRECHETTE, K. Scientific method, anti-foundationalism and public decisionmaking. Issue in Health and Safety, I (I): 23-4I, 1990. Disponível em: <http://ipmall.info/risk/ voll/winter/shrader.htm>.Acesso em: 10 out. 2013.

SHRADER-FRECHETTE, K. Evaluating the expertise of experts. Risk: Environment, Health, and Safety, 6(2): I I5- I26, 1995. Disponível em: <http://nd.edu/ kshrader/pubs/ risk_6_II5_evaluating_expertise.pdf>.Acesso em: 10 out. 2013.

SHRADER-FRECHETTE, K. Environmental ethics. In: LaFOLLETTE, H. (Ed.). The Oxford Handbook of Practical Ethics. Oxford: Oxford University Press, 2003.

SINGER, P. Ética Prática. São Paulo: Martins Fontes, 1994.

SIQUEIRA-BATISTA, R. \& SCHRAMM, F. R.A bioética da proteção e a compaixão laica: o debate moral sobre a eutanásia. Ciência \& Saúde Coletiva, I4(4): I.24| - I.250, 2009.

SLOTERDIJK, P. Regras para o Parque Humano: uma resposta à carta de Heidegger sobre o humanismo. São Paulo: Estação Liberdade, 2000.

SNOW, C. P. The Two Cultures. London: Cambridge University Press, 1959.

STEINER, G. Heidegger. México: Fondo de Cultura Económica, 200 I.

SULSTON, J. El Genoma y la División de Clases: conversaciones con Jorge Halperlín. Buenos Aires: Capital Intelectual, 2007.

SULSTON, J. \& FERRY, G. El Hilo Común de la Humanidad: una historia sobre la ciencia, la política, la ética y el genoma humano. Madrid: Siglo XXI, 2003.

TANGWA, G. B. Globalisation or Westernisation? Ethical concerns in the whole biobusiness. Bioethics, 13(3/4): 218-226, 1999.

TANNER, M. Nietzsche. São Paulo: Loyola, 2004. 
TEIXEIRA, P. \& VALLE, S. Biossegurança: uma abordagem multidisciplinar. Rio de Janeiro: Editora Fiocruz, 1996.

WITTGENSTEIN, L. Philosophische Untersuchungen. Oxford: Basic Blackwell, 1953.

WITTGENSTEIN, L. Tratado Lógico-Filosófico. Lisboa: Fundação Calouste Gulbenkian, 1987.

WITTGENSTEIN, L. Da Certeza. Lisboa: Edições 70, 1990.

WITTGENSTEIN, L. Investigações Filosóficas. Petrópolis:Vozes, 2005.

ZINGARELLI, N. II Nuovo Zingarelli: vocabolario della lingia italiana. I I. ed. Bologna:

Zanichelli, 1984.

ZORRILLA, S. Persistencia y profundización del conflicto de interés. Perspectivas Éticas, 19: 65-84, 2007.

ZUPANČIČ,A. Etica del Reale: Kant, Lacan. Napoli: Orthotes Editrice, 2012. 
Formato: 16 × $23 \mathrm{~cm}$

Tipologia: Aldus, Gill Sans MT, Stone Serif, GeoSlab 703MT (miolo/capa)

Papel: Pólen Bold 70g/ $\mathrm{m}^{2}$ (miolo)

Cartão Supremo $250 \mathrm{~g} / \mathrm{m}^{2}$ (capa)

CTP, Impressão e acabamento: Imos Gráfica e Editora Ltda.

Rio de Janeiro, março de 2015.

Não encontrando nossos títulos em livrarias,

contactar a Editora Fiocruz:

Av. Brasil, 4036 - térreo - Manguinhos

21040-361 - Rio de Janeiro - RJ

Telefones: (21) 3882-9039 e 3882-9041

Telefax: (21) 3882-9006

editora@fiocruz.br

www.fiocruz.br/editora 